Report of Investigation 2020-8

\title{
MINERAL OCCURRENCES IN THE TOK RIVER AREA, EASTERN ALASKA RANGE
}

Evan Twelker, Rainer J. Newberry, Alicja Wypych, Karri R. Sicard, and Travis J. Naibert

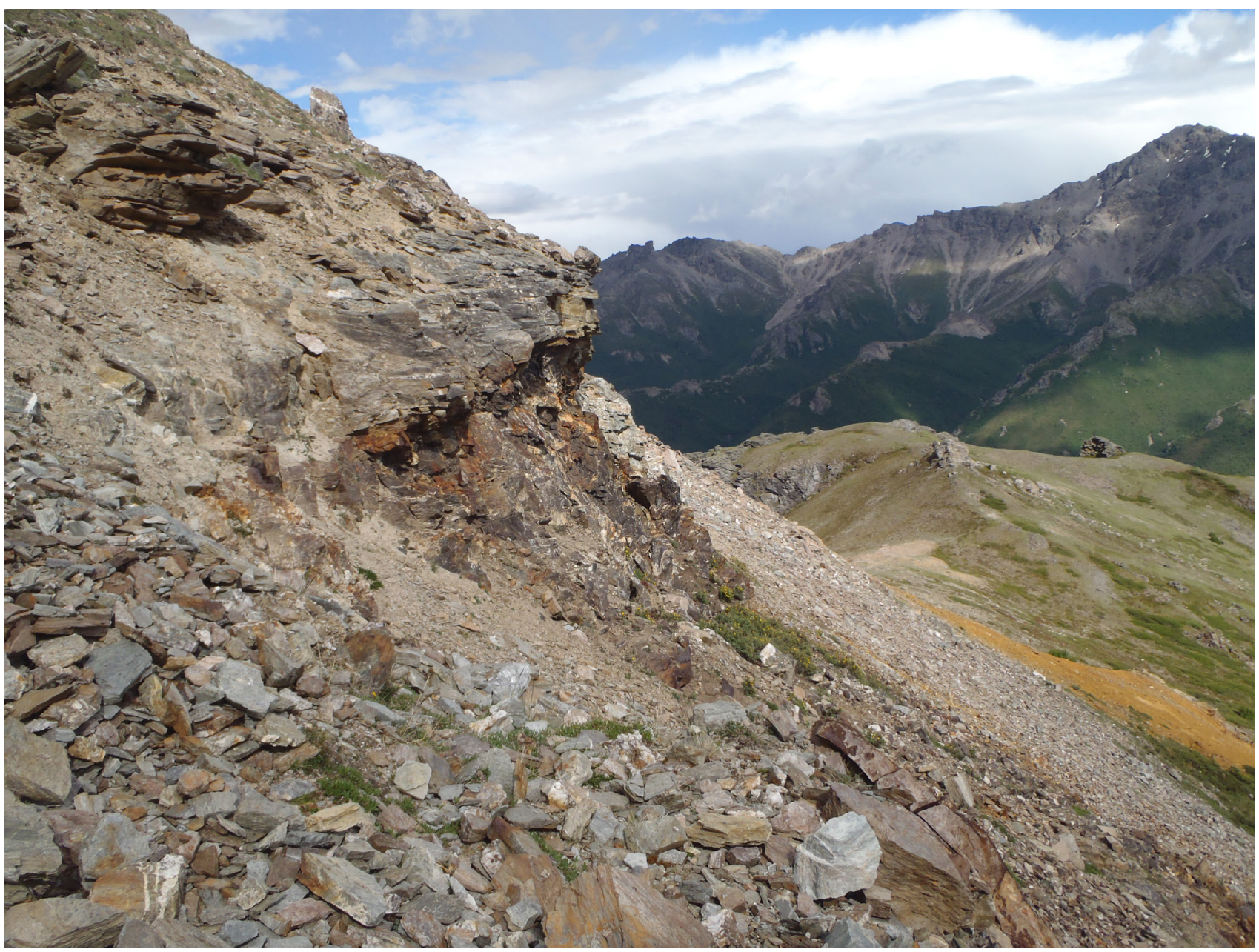

Massive sulfide mineralization in outcrop at the Wrinkle Extension prospect; view is to the north-northwest.

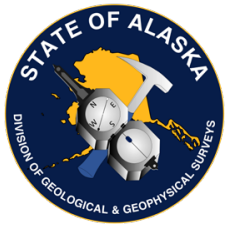

Published by STATE OF ALASKA

DEPARTMENT OF NATURAL RESOURCES DIVISION OF GEOLOGICAL \& GEOPHYSICAL SURVEYS 



\section{MINERAL OCCURRENCES IN THE TOK RIVER AREA, EASTERN ALASKA RANGE}

Evan Twelker, Rainer J. Newberry, Alicja Wypych, Karri R. Sicard, and Travis J. Naibert

Report of Investigation 2020-8

State of Alaska

Department of Natural Resources

Division of Geological \& Geophysical Surveys 


\section{STATE OF ALASKA}

Mike Dunleavy, Governor

\section{DEPARTMENT OF NATURAL RESOURCES}

Corri A. Feige, Commissioner

\section{DIVISION OF GEOLOGICAL \& GEOPHYSICAL SURVEYS}

Steve Masterman, State Geologist and Director

Publications produced by the Division of Geological \&

Geophysical Surveys (DGGS) are available for free download

from the DGGS website (dggs.alaska.gov). Publications on

hard-copy or digital media can be examined or purchased in

the Fairbanks office:

Alaska Division of Geological \& Geophysical Surveys

3354 College Rd., Fairbanks, Alaska 99709-3707

Phone: (907) 451-5010 Fax (907) 451-5050

dggspubs@alaska.gov|dggs.alaska.gov

\section{DGGS publications are also available at:}

Alaska State Library,

Historical Collections \& Talking Book Center

395 Whittier Street

Juneau, Alaska 99811

Alaska Resource Library and Information Services (ARLIS)

3150 C Street, Suite 100

Anchorage, Alaska 99503

\section{Suggested citation:}

Twelker, Evan, Newberry, R.J., Wypych, Alicja, Sicard, K.R., and Naibert, T.J., 2020, Mineral occurrences in the Tok River area, Eastern Alaska Range: Alaska Division of Geological \& Geophysical Surveys Report of Investigation 2020-8, 49 p. http://doi. org/10.14509/30471
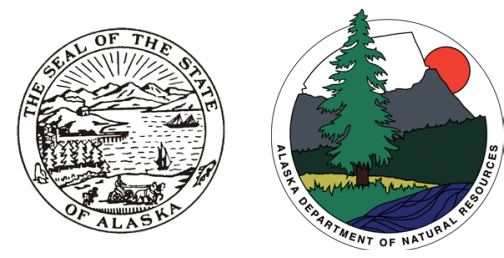



\section{Contents}

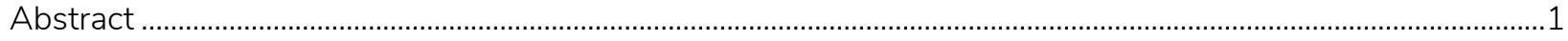

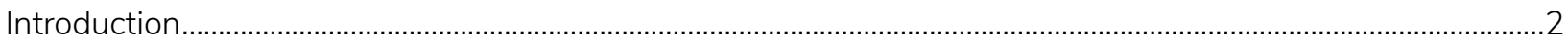

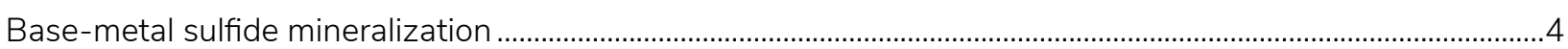

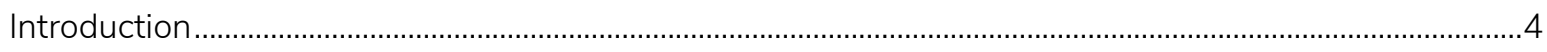

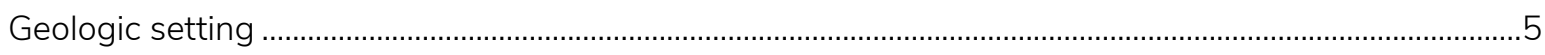

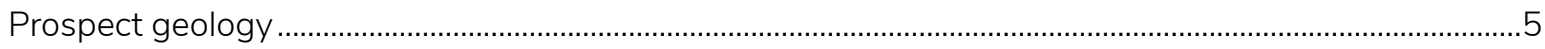

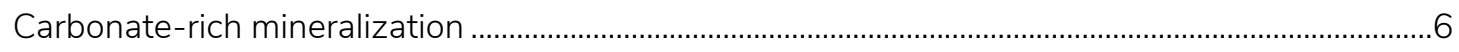

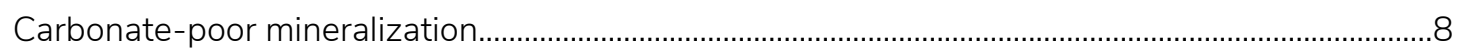

Calc-silicate-rich mineralization ....................................................................................................... 8

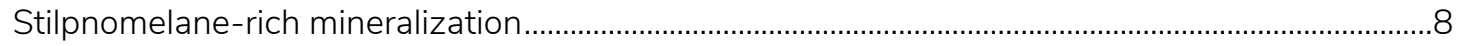

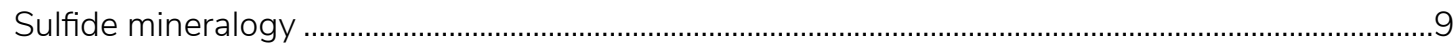

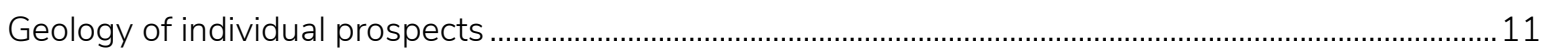

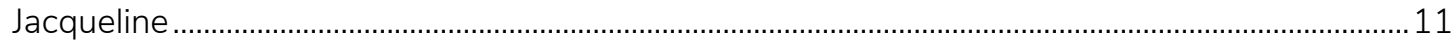

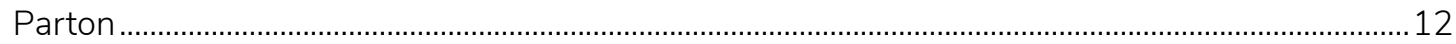

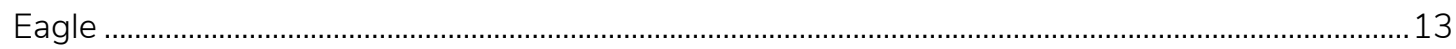

Calc-silicate-rich occurrence west of Conehead............................................................................ 14

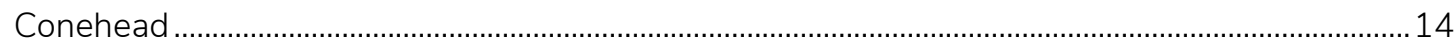

$\mathrm{NiC}$

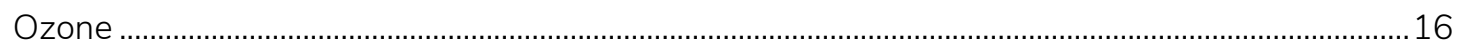

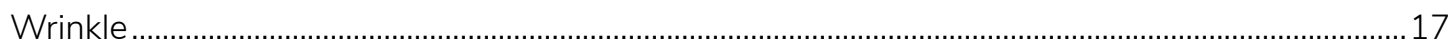

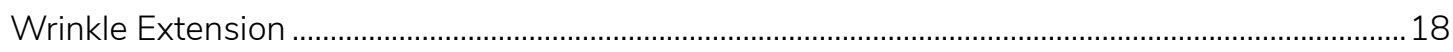

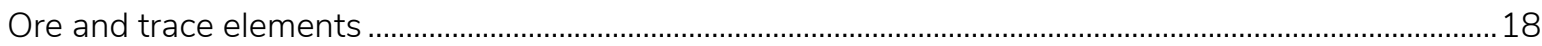

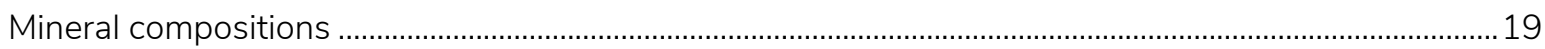

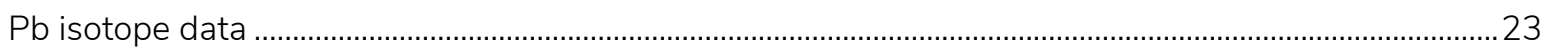

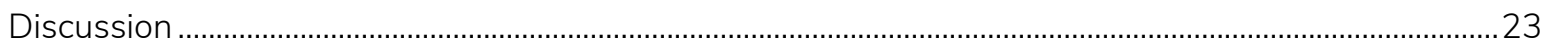

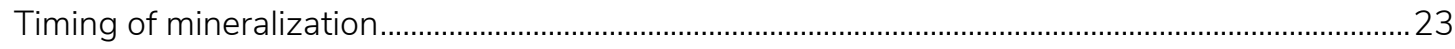

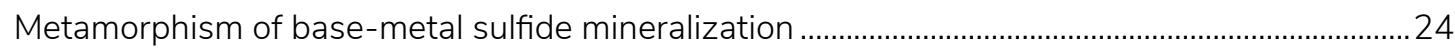

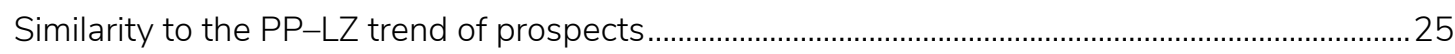

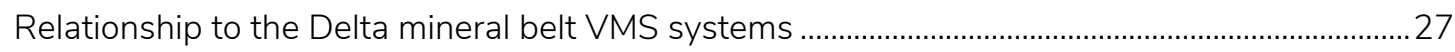

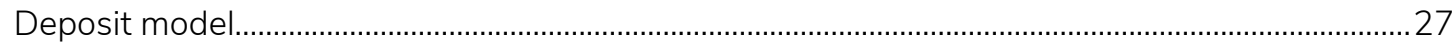

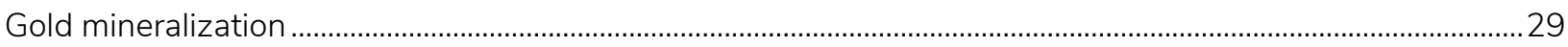

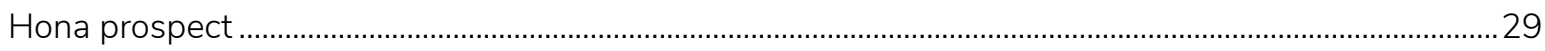

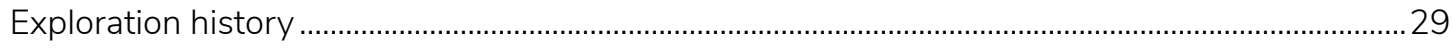

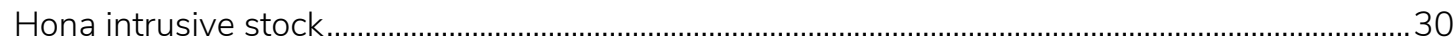

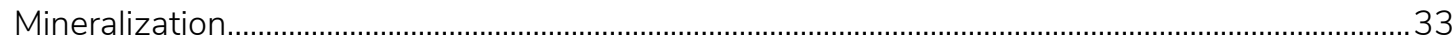

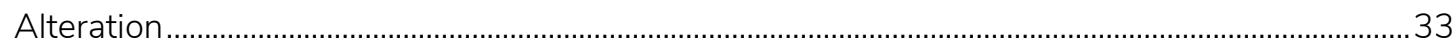

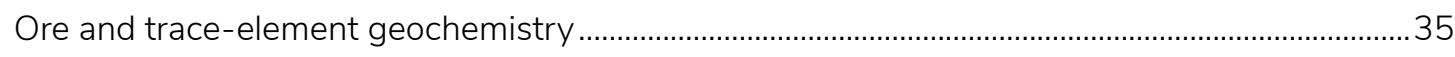

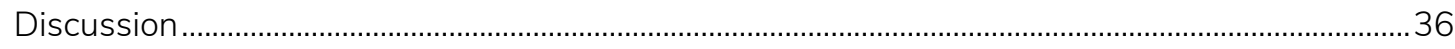

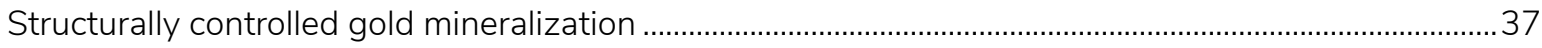

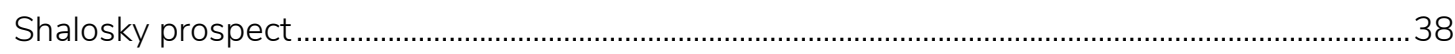

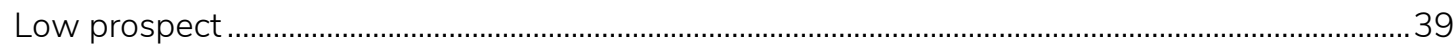

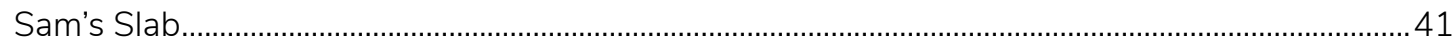

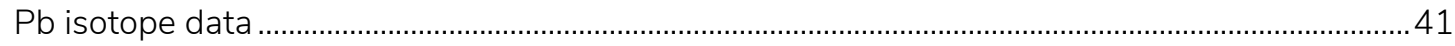

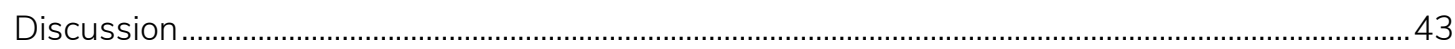




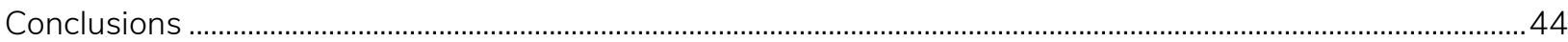

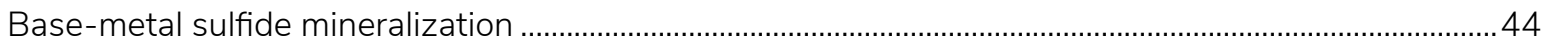

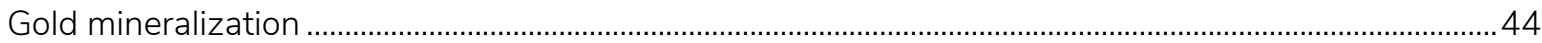

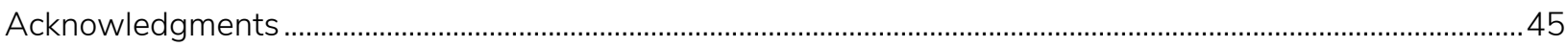

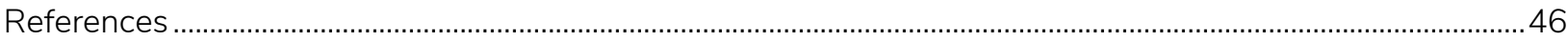

\section{Figures}

Figure 1. Map showing the geographic and general geologic context of the study area...................................2

Figure 2. Geologic map of the study area, including locations of key mineral occurrences..................................

Figure 3. Location and geologic setting of base-metal sulfide prospects in the southeastern

Tanacross A-6 Quadrangle ....................................................................................................................................

Figure 4. Map showing the distribution of mapped marble layers, $900 \mathrm{~Hz}$ resistivity, base-metal

mineral occurrences, and selected geological features ....................................................................................

Figure 5. Photograph of typical calcite-rich sulfide mineralization at the Nic prospect .........................................8

Figure 6. Photographs of calcite-poor sulfidic rocks from the Eagle prospect........................................................9

Figure 7. Twinned albite porphyroblast surrounded by white mica and chlorite ....................................................9

Figure 8. Photomicrographs. Sample from the Jacqueline prospect; 16RN268; XPL ..................................... 10

Figure 9. Photomicrographs from the lower Ozone prospect (16RN161C) and west of Conehead

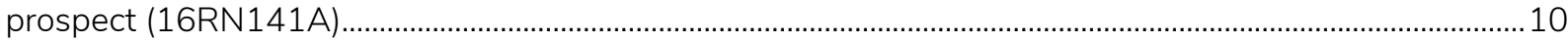

Figure 10. Photomicrographs from the Eagle, upper Ozone, and Parton prospects ........................................11

Figure 11. Map showing the distribution of rock types recorded at stations in the vicinity of the

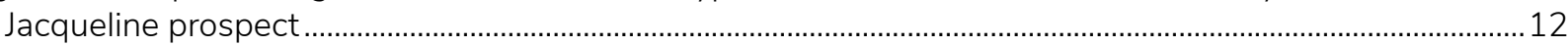

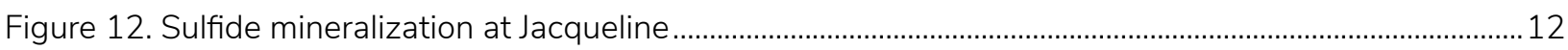

Figure 13. Idealized sketch cross-section through the Parton prospect ..........................................................13

Figure 14. Highly idealized sketch of a cliff face at the Eagle prospect..................................................................14

Figure 15. Massive sulfide mineralization at the Conehead prospect......................................................................15

Figure 16. Sketch map of the Nic prospect showing the three different types of sulfide occurrences spread out over approximately $150 \mathrm{~m}$.............................................................................................. 16

Figure 17. Generalized sketch of the Wrinkle prospect outcrop ...........................................................................17

Figure 18. Photos of the Wrinkle Extension prospect........................................................................................ 18

Figure 19. Ternary diagram showing relative proportions of $\mathrm{Zn}, \mathrm{Pb}$, and $\mathrm{Cu}$ for base-metal

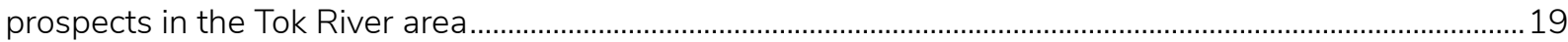

Figure 20. Bivariate scatterplot for trace elements at base-metal occurrences in the Tok River area............19

Figure 21. Garnet and clinopyroxene compositions from prospects in the Tanacross A-6 Quadrangle ........21

Figure 22. Calcite-dolomite geothermometry of sample 16RN213C (Eagle prospect) ....................................24

Figure 23. ICP-MS Pb isotopic data from base-metal prospects in the Tanacross A- 6 Quadrangle plotted against data from the nearby Late Cretaceous Peak Au-Cu-Ag skarn and Devonian to Mississippian VMS occurrences including the Delta Mineral belt.....

Figure 24. FeS content (in percent) of sphalerite in equilibrium with the assemblage pyritepyrrhotite (numbered curves) as a function of temperature and pressure ......................................................26

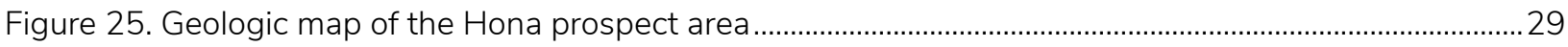

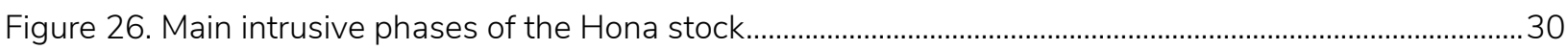

Figure 27. Mineralization in the country rock adjacent to the Hona stock ..........................................................31

Figure 29. Photomicrographs of altered and mineralized intrusion breccia at Hona .........................................32

Figure 28. Distribution of alteration mineral assemblages and sulfide minerals at the Hona prospect..........32

Figure 30. Hand sample showing altered and mineralized intrusion breccia at the Hona prospect................33 
Figure 31. Map showing Au, Ag, Cu, and As geochemical data

Figure 32. Bivariate scatter plots showing the concentration of selected elements at Hona, White Gold trend prospects Low and Shalsosky, and the Taurus Cu-Mo-Au porphyry system.... .35

Figure 33. Geochemical classification diagrams showing the similarities between intrusive and volcanic rocks at Hona and the Tetlin property..... 36

Figure 34. Inset of geologic map of the White Gold trend of structurally controlled gold prospects...............38

Figure 35. Photomicrograph (XPL) and ${ }^{40} \mathrm{Ar} /{ }^{39} \mathrm{Ar}$ spectrum diagram of bleached metamorphic wall rock inclusion (sample 15ET005) within the Shalosky gold-mineralized quartz vein and shear zone......39

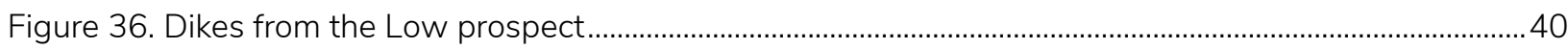

Figure 37. Chondrite-normalized REE diagram after Boynton (1984) showing samples from the Hona intrusion and 'Low-type' dikes

Figure 38. Sam's Slab quartz vein, parallel dike, and altered country rock.

Figure 39. ICP-MS Pb isotopic data from gold prospects in the Tanacross A-5 and A-6 quadrangles plotted against data from the nearby Late Cretaceous Peak Au-Cu-Ag skarn, Jurassic orogenic gold systems in Yukon, and Devonian to Mississippian VMS occurrences including the Delta Mineral belt.

\section{Tables}

Table 1. Mineralogy and grade of selected samples from base-metal prospects in the Tanacross A-6 Quadrangle.

Table 2. Layers present in a marble-rich outcrop, Jacqueline prospect................................................................13

Table 3. Composition (weight percent) and FeS content (molecular percent) of sphalerite from base-metal prospects in the Tanacross A-6 Quadrangle.

Table 4. Pyroxene compositions, averaged by sample, for prospects in the Tanacross A-6 Quadrangle......21

Table 5. Garnet compositions (microprobe EDS) from Tanacross A-6 Quadrangle prospects ........................22

Table 6. Actinolite compositions (microprobe EDS) from Tanacross A-6 prospects............................................23

Table 7. Average microprobe (EDS) analyses of adjacent and intergrown calcite and ferroan dolomite grains in sample 16RN213C (Eagle prospect) ....................................................................................24

Table 8. Whole-rock ICP-MS Pb isotopic ratios for $\mathrm{Pb}$-rich samples from base-metal prospects in the Tanacross A-6 Quadrangle. 


\title{
MINERAL OCCURRENCES IN THE TOK RIVER AREA, EASTERN ALASKA RANGE
}

Evan Twelker ${ }^{1}$, Rainer J. Newberry², Alicja Wypych ${ }^{1}$, Karri R. Sicard ${ }^{1}$, and Travis J. Naibert ${ }^{1}$

\begin{abstract}
The Tok River area (Tanacross A-5 and A-6 quadrangles) of the eastern Alaska Range hosts a variety of ages and styles of mineralization, including stratabound basemetal sulfide, intrusion-related gold-copper-silver, and structurally controlled gold.

Stratabound base-metal ( $\mathrm{Zn}-\mathrm{Pb}-\mathrm{Cu}-\mathrm{Ag}-\mathrm{Au})$ sulfide prospects occur in the Tanacross A-6 Quadrangle, where they are known in part as the Eagle trend. Mineralization is hosted by thin marble beds within a metamorphic package dominated by siliciclastic and rare volcanic protoliths. Sulfide minerals include sphalerite, galena, chalcopyrite, pyrrhotite, and pyrite; associated minerals include calcite, ankerite, siderite, albite, phengite, chlorite, ferro-actinolite, stilpnomelane, Fe-clinopyroxene, Ca-Mn garnet, ilvaite, and barite. Mineral assemblages, compositions, and textures indicate that base-metal sulfide mineralization experienced Permian through Jurassic regional metamorphism, and $\mathrm{Pb}$-isotopic ratios are closely similar to those of Devonian to Mississippian syngenetic deposits of Interior Alaska. We interpret the Eagle trend to be a continuation of the PP-LZ trend of the Delta mineral belt, and that the Tok River area prospects are most similar to sedimentary-exhalative (SEDEX)-type systems.
\end{abstract}

The Hona prospect comprises Au-Cu-Ag mineralization developed in association with a multiphase hypabyssal granodiorite stock of Late Cretaceous (ca. $75 \mathrm{Ma}$ ) age. Mineralization occurs with disseminated pyrrhotite, chalcopyrite, trace molybdenite, and secondary biotite within the intrusion, and with disseminated and veinlet-hosted pyrite and chalcopyrite in adjacent metamorphic rocks. Silicification, sodic, and argillic alteration occur locally, but well-developed sericitic alteration is lacking. The prospect is similar in age to the nearby Peak gold skarn and is associated with intrusions of similar composition. The geochemical signature of Hona mineralization ( $\mathrm{Au}-\mathrm{Cu}-\mathrm{Ag}-\mathrm{As}-\mathrm{Bi}-\mathrm{Te}$ ) is similar to that of the Peak skarn and distinct from the coeval Taurus Cu-Mo-Au porphyry system.

Structurally controlled gold prospects of the White Gold trend appear to have formed well after mid-Cretaceous metamorphic cooling. Mafic and felsic dikes of likely Paleogene age occur locally with structurally controlled gold mineralization and are both pre-/syn- and post-mineralization in timing. Advanced argillic alteration affects Au-As-mineralized dikes as well as mineralized country rock; such alteration reflects highly acidic hydrothermal fluids and is inconsistent with an orogenic gold deposit model. If the White Gold prospects were emplaced during the Paleocene, they are similar in age and style to the Hajdukovich property near Delta Junction and may be genetically linked to ca. $55 \mathrm{Ma}$ extensional tectonics and magmatism.

\footnotetext{
${ }^{1}$ Alaska Division of Geological \& Geophysical Surveys, 3354 College Rd., Fairbanks, Alaska 99709-3707

2 Department of Geosciences, University of Alaska, P.O. Box 755780, Fairbanks, AK 99775-5780
} 


\section{INTRODUCTION}

The Tok River geological map area (Tanacross A-6 and A-5 quadrangles) lies north of the Denali fault in an area of the eastern Alaska Range underlain by Devonian to Mississippian metasedimentary and metavolcanic rocks of parautochthonous North America. It is intruded by dikes, sills, and stocks of Triassic, Late Cretaceous, and Tertiary ages (figs. 1, 2 ). The area lies between two exploration properties where work has advanced to the point of mineral resource definition: the Late Devonian volcanogenic massive sulfide (VMS) deposits of the Delta mineral belt lie immediately to the west of the study area (Dashevsky and others, 2003), and the Late
Cretaceous gold-copper-silver (Au-Cu-Ag) marble replacement deposits on the Tetlin Reservation lie immediately to the east (Illig, 2015). Understanding the possible continuation of these mineral systems into the Tok River area was a primary goal of this study. Additionally, the Tok River area hosts two clusters of structurally controlled gold prospects, the White Gold and AR trends (fig. 2; Dashevsky and others, 2003). The geologic model, age, and regional context of these gold systems are poorly constrained, and resolving some of these uncertainties was a secondary goal of this study.

The Alaska Division of Geological \& Geophysical Surveys (DGGS) conducted geologic mapping and

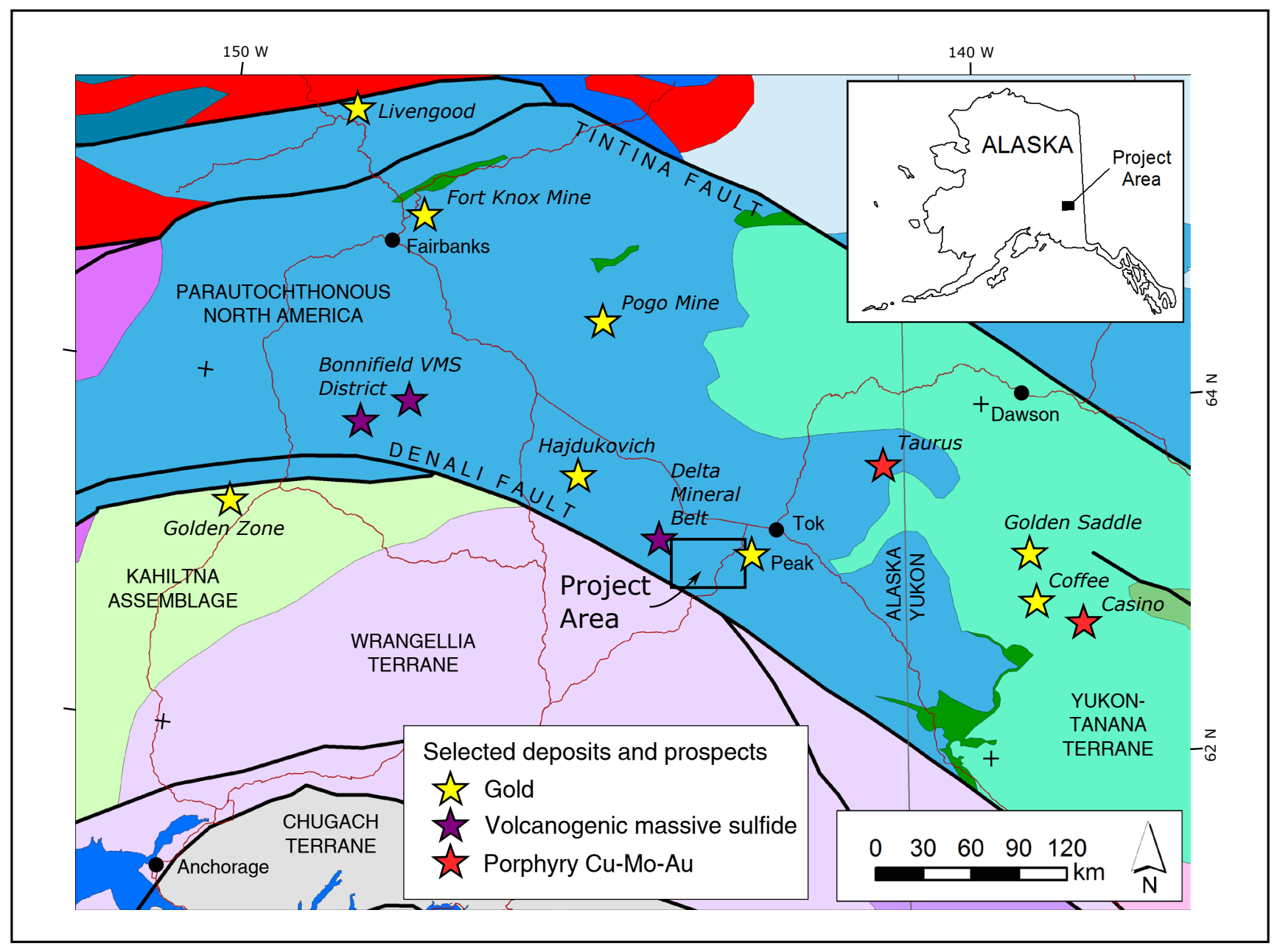

Figure 1. Map showing the geographic and general geologic context of the study area, including selected nearby mineral deposits and prospects. Modified from terrane map of Colpron and Nelson (2011). 
sampling in the Tok River area during the 2015 and 2016 field seasons, and data released to date includes geochemical reports (Wypych and others, 2015, 2016; Naibert and others, 2016), geochronology (Benowitz and others, 2017; Holm-Denoma and others, 2020), and the map itself (Sicard and others, 2017). This report presents the results of economic geology studies conducted during the mapping effort. These studies were primarily completed by authors Newberry and Twelker, with contributions from Wypych, Sicard, and Naibert focused on the geologic and geochemical context of the mineral systems.

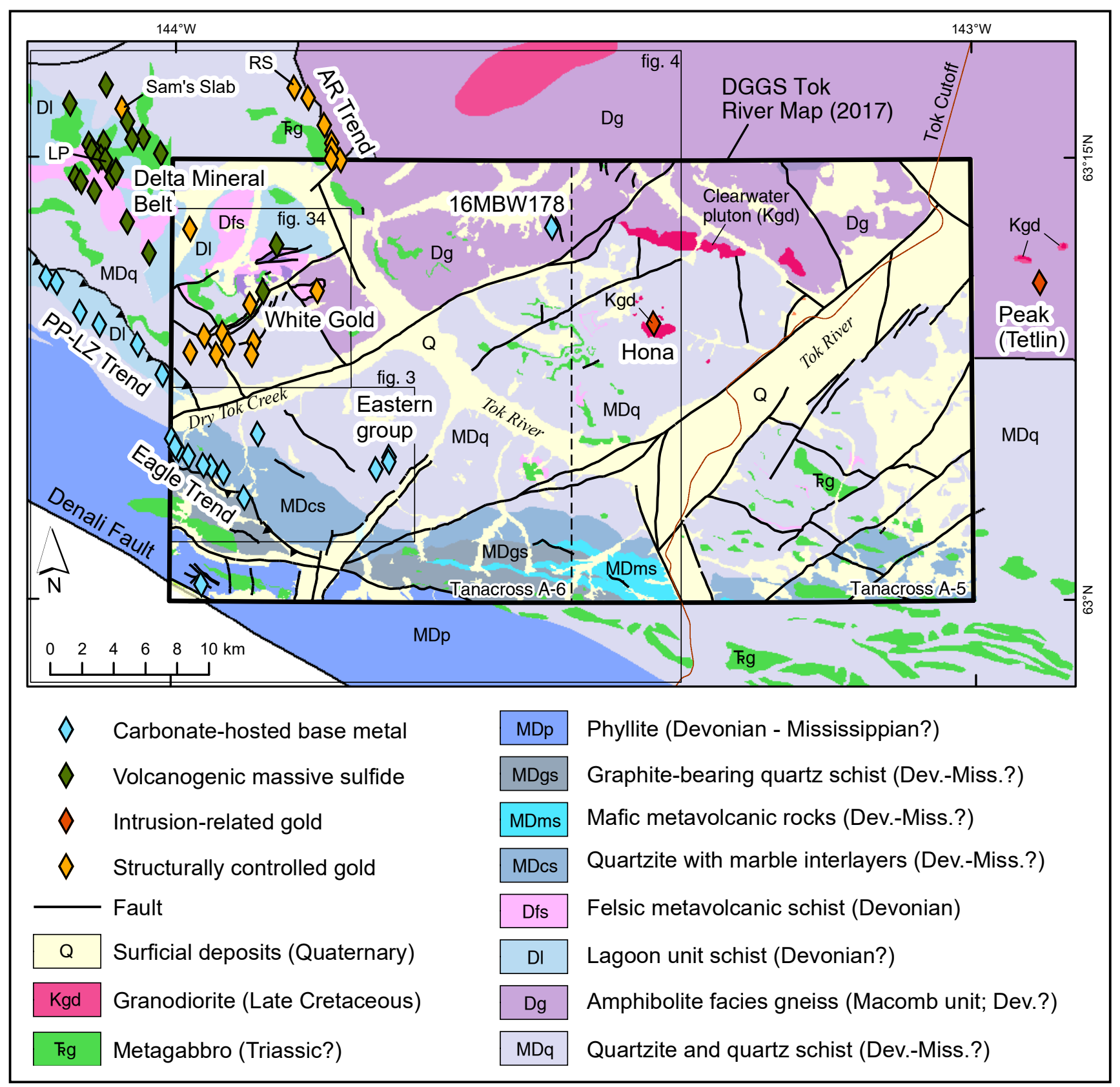

Figure 2. Geologic map of the study area, including locations of key mineral occurrences. Geology adapted from Sicard and others (2017), Dashevsky and others (2003), Wilson and others (2015), and Illig (2015). Prospect locations adapted from Alaska Resource Data File (U.S. Geological Survey, 2018), Degenhart (1978), and this study. 


\section{BASE-METAL SULFIDE MINERALIZATION Introduction}

The Tok River area (Tanacross A-6 and A-5 quadrangles; fig. 2) lies between the Late Devonian VMS deposits of the Delta mineral belt and the Late Cretaceous $\mathrm{Au}-\mathrm{Cu}-\mathrm{Ag}$ marble replacement deposits on the Tetlin Reservation, including the Peak skarn (Illig, 2015). In the late 1970's, WGM Inc. geologists led by Clint Degenhart evaluated the Tok River area on behalf of Ahtna Inc. and discovered a group of marble-hosted base-metal sulfide prospects (Degenhart, 1978). With the permission of Ahtna Inc., DGGS was able to secure copies of the WGM Inc. reports and revisit these prospects in the southwest corner of the Tanacross A-6 Quadrangle (fig. 3).

A central question motivating recent mapping by DGGS in the Tok River area was whether the

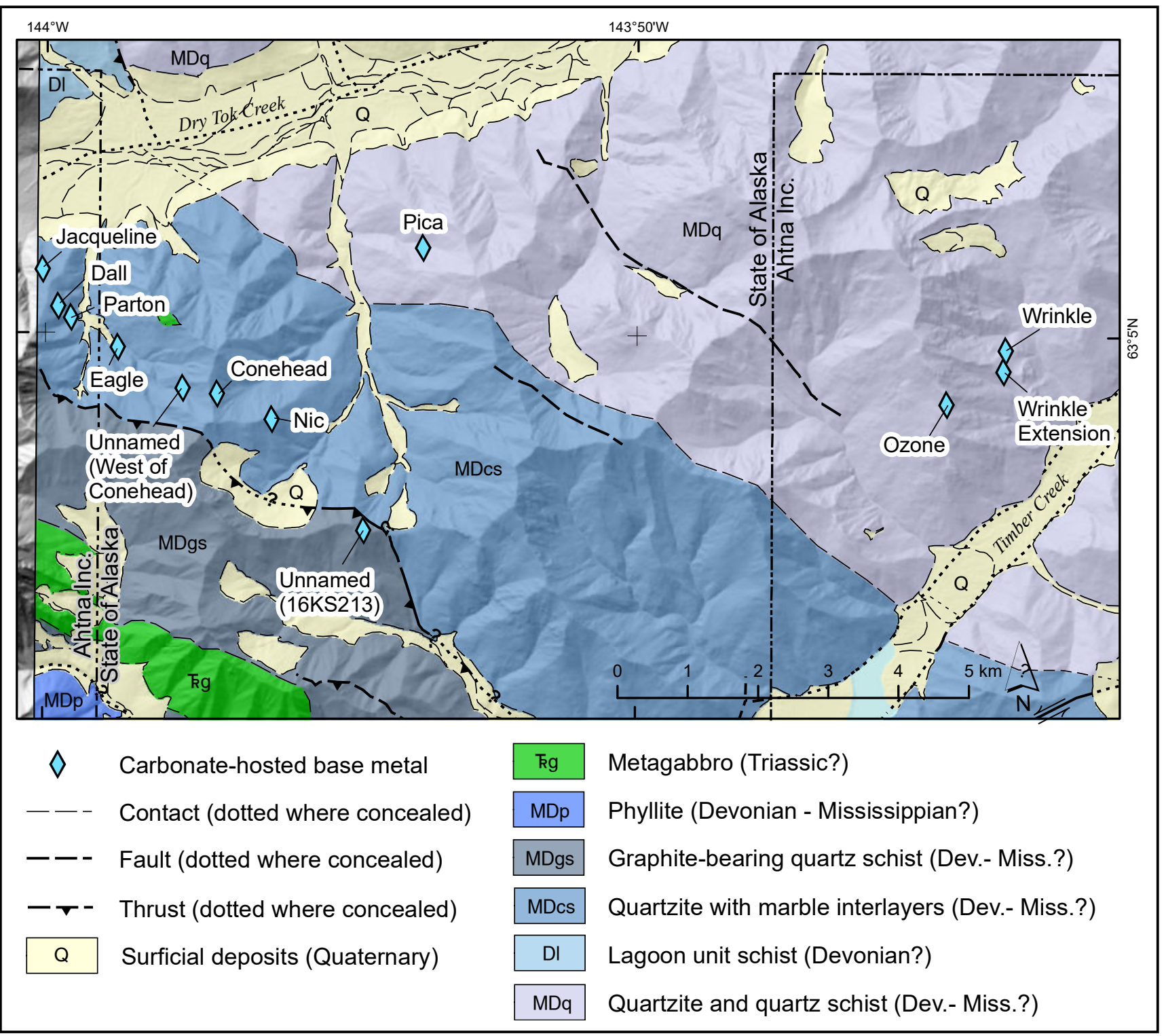

Figure 3. Location and geologic setting of base-metal sulfide prospects in the southeastern Tanacross A-6 Quadrangle. Geologic map adapted from Sicard and others (2017). 
VMS-prospective rocks of the Delta mineral belt continue into the Tanacross Quadrangle. If these rocks do continue, where are they located, and how are they similar to, or different from, the rocks associated with mineralization in the Delta mineral belt? How do the base-metal sulfide prospects of the Tanacross A-6 Quadrangle relate to those of the Delta mineral belt?

Another possibility, especially relevant given the marble-replacement style and calc-silicate gangue of base-metal mineralization in the Tanacross A-6 Quadrangle, is that these prospects are instead related to Late Cretaceous (post-regional metamorphism) magmatic-hydrothermal systems. Such systems include the Peak skarn deposit on the Tetlin Reservation and the Hona $\mathrm{Au}-\mathrm{Cu}$ prospect in the Tanacross A-5 Quadrangle.

In order to better resolve the geologic model of these base-metal prospects and to establish the most likely regional analogs, we completed a program of geochemical sampling, petrography, microprobe work, and $\mathrm{Pb}$ isotope analysis. Results indicate that these stratabound base-metal sulfide prospects formed prior to metamorphism and represent a continuation of the PP-LZ trend, part of the Late Devonian Delta mineral belt massive sulfide system. The differences between the Tanacross A- 6 prospects and the Delta mineral belt may be explained by differences in both deposit model and metamorphic grade.

\section{Geologic setting}

The host rocks of the base-metal occurrences in the study area are strongly deformed greenschist facies metamorphic rocks of the Jarvis Creek Glacier subterrane (Nokleberg and others, 2015), also known as the Jarvis belt (Dashevsky and others, 2003; Dusel-Bacon and others, 2006). Most of the base-metal sulfide prospects (Jacqueline through Nic; collectively called the Eagle trend) are hosted by unit MDcs of Sicard and others (2017), a northwest-striking, southwest-dipping Devonian to Mississippian(?) assemblage of interlayered quartzite, quartz schist, and significant (about 23 percent of the unit) interbedded thin layers of marble and calcareous schist. These carbonate layers range from 0.1 to $20 \mathrm{~m}$ in thickness; thicker layers may be continuous over strike distances of several kilometers. The unit also contains interlayered mafic to felsic metavolcanic rocks that are too discontinuous or volumetrically minor to be mapped at a scale of $1: 63,360$. Although the unit is not consistently graphitic, it contains abundant graphitic schist layers and appears as a moderately conductive region in the DGGS $900-\mathrm{Hz}$ airborne resistivity survey (fig. 4; Emond and others, 2015). The Wrinkle, Wrinkle Extension, and Ozone prospects, referred to in this report as the "eastern group," lie east of the Eagle trend and are hosted by isolated layers of marble within quartzite and quartz schist (unit MDq of Sicard and others, 2017).

\section{Prospect geology}

The host rocks for all base-metal sulfide prospects are layers of impure marble, typically 1 to $5 \mathrm{~m}$ thick, separated by intervening quartz schist layers ranging from 1 to $10 \mathrm{~m}$ in thickness. At the Wrinkle, Parton, and Eagle prospects, one impure marble layer hosts all the mineralization. However, at Nic, Ozone, and Jacqueline, mineralized rocks are present in several different impure marble layers, and the marble is repeated by intense isoclinal folding. At the Conehead prospect, marble is absent except for a $10-\mathrm{cm}$-thick band in the hanging wall of one sulfide lens. The host marbles are uniformly calcic (not dolomitic) and typically contain 60 to 70 percent calcite, 10 to 30 percent quartz, 3 to 15 percent muscovite, and 1 to 5 percent chlorite.

Based on visual estimates and X-ray fluorescence (XRF) analyses, the mineralized rocks rarely contain more than 35 percent sulfide minerals, and they commonly contain 10 to 25 percent total sulfides. In many cases, base-metal sulfides (sphalerite, chalcopyrite, galena) are greater than or equal to total iron sulfide. This is in considerable contrast to VMS ores 


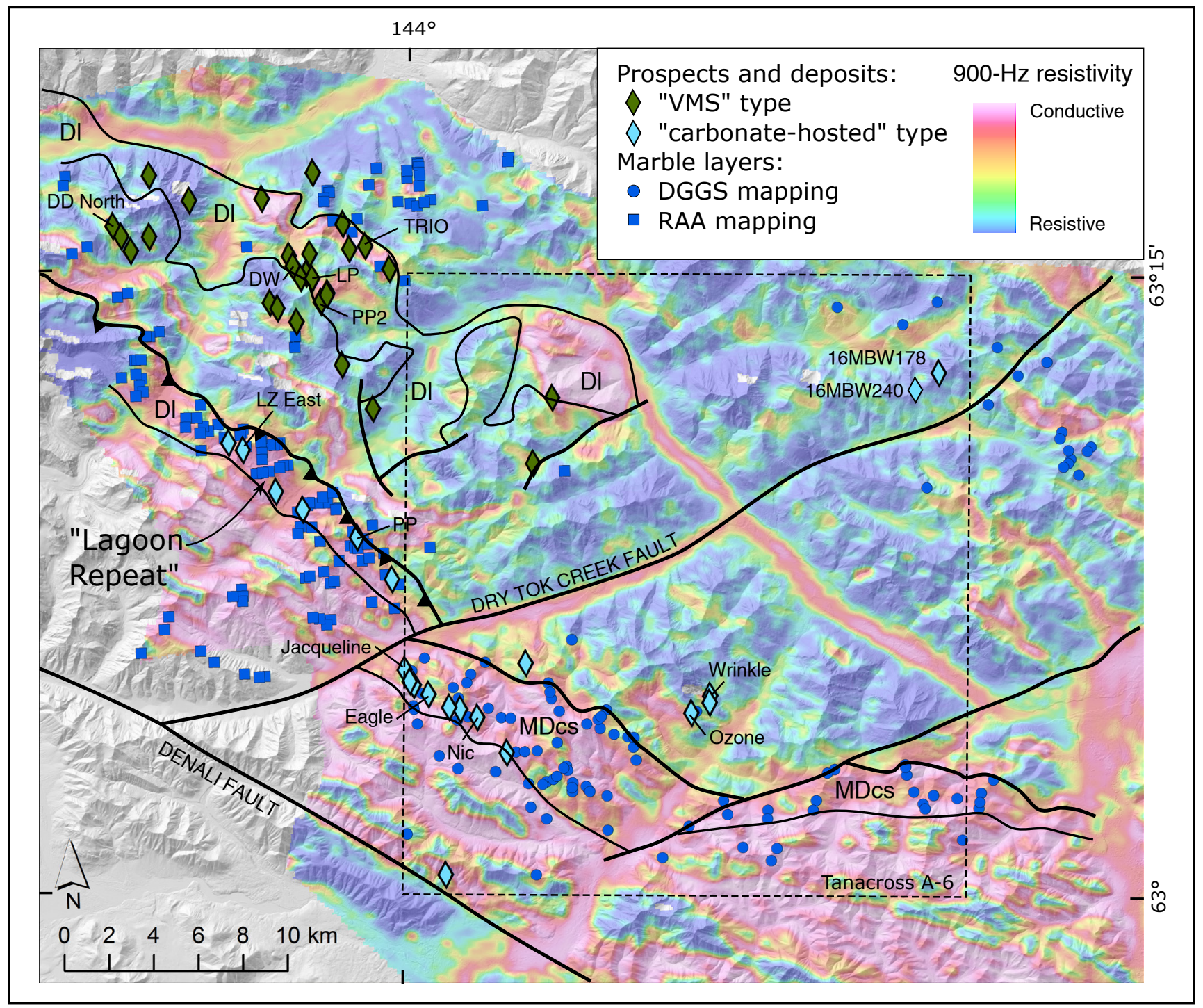

Figure 4. Map showing the distribution of mapped marble layers, 900-Hz resistivity (Emond and others, 2015), base-metal mineral occurrences, and selected geological features adapted from Sicard and others (2017) and Dashevsky and others (2003). "DI": Lagoon unit of Dashevsky and others (2003); "MDcs": quartzite and quartz schist with calcareous schist and marble of Sicard and others (2017). Marble locations are adapted from DGGS (Sicard and others, 2017) and from unpublished mapping by Resource Associates of Alaska (RAA).

of the Delta district, for which total sulfide constitutes 75 to 90 percent of the rock and the ratio of Fe-sulfide to base-metal sulfide ranges from 2 to 8 (Rao, 1988).

We have identified four major types of metalliferous rocks among the sulfide prospects of the southwest Tanacross A-6 Quadrangle: (1) carbonate-rich, (2) carbonate-poor, (3) calc-silicate-rich ("skarn," in the non-genetic sense), and (4) stilpnomelane-rich. Most prospects contain several types, and the Jacqueline prospect, at the northwest end of the Eagle trend (fig. 3), contains all four types spread out over an area of approximately 100 $\mathrm{m}$ by $200 \mathrm{~m}$.

\section{Carbonate-rich mineralization}

Approximately one-third of the sulfidic rocks observed during this study are "carbonate rich" (table 1; fig. 5); that is, they contain more than 
about 30 percent carbonate. The remainder is a mix of quartz, sulfides, and either chlorite or stilpnomelane. In most cases the carbonate is calcite; ankerite and Mn-bearing siderite are also notably present (table 1). The sulfide content is typically about 5 to 20 percent, and the most abundant iron sulfide is

Table 1. Mineralogy and grade of selected samples from base-metal prospects in the Tanacross A-6 Quadrangle. Mineralogy determined by microprobe energy-dispersive X-ray spectroscopy (EDS) and optical techniques. Geochemistry from Wypych and others (2016). Mineralization type abbreviations: CR - Carbonate-rich; CP - carbonate-poor; ST - stilpnomelane-rich; CS - calc-silicate-rich.

\begin{tabular}{|c|c|c|c|c|c|c|c|c|c|c|c|c|c|c|c|c|c|c|c|c|c|c|c|c|c|}
\hline Prospect/ Sample No. & 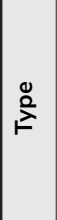 & 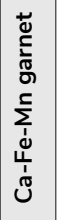 & 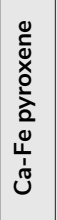 & $\begin{array}{l}\stackrel{ \pm}{\frac{\pi}{\pi}} \\
\stackrel{2}{\geqq}\end{array}$ & 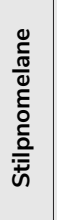 & 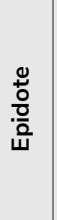 & 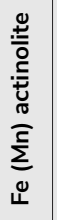 & $\begin{array}{l}\stackrel{ \pm}{\frac{0}{t}} \\
\frac{0}{\frac{1}{U}}\end{array}$ & $\frac{\stackrel{ \pm}{0}}{\frac{0}{2}}$ & 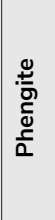 & 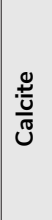 & 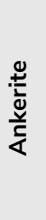 & 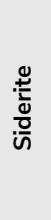 & $\begin{array}{l}O^{m} \\
\text { ড় }\end{array}$ & 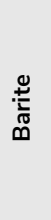 & 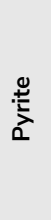 & 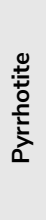 & 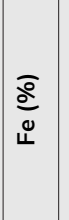 & $\frac{\bar{\jmath}}{\frac{c}{\Sigma}}$ & 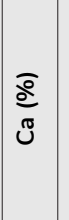 & $\frac{\grave{g}}{\mathfrak{N}}$ & $\frac{\bar{a}}{\frac{0}{2}}$ & $\frac{\grave{\jmath}}{3}$ & $\begin{array}{l}\bar{\varepsilon} \\
\frac{0}{0} \\
\frac{0}{\alpha}\end{array}$ & $\begin{array}{l}\bar{\varepsilon} \\
\text { 을 } \\
\bar{z}\end{array}$ \\
\hline \multicolumn{26}{|l|}{ Jacqueline } \\
\hline 16RN265A & $\mathrm{CR}$ & $x$ & & & $x$ & & & $x$ & & & $x$ & & $x$ & & $x$ & $x$ & $x$ & 12.2 & 1.4 & 12.5 & 2.0 & 0.0 & 0.1 & 1.72 & 0.011 \\
\hline 16RN265D & $\mathrm{CR}$ & & & & & & $x$ & $x$ & & & & & & & & $x$ & $x$ & 21.9 & 0.6 & 8.9 & 3.6 & 0.1 & 0.2 & 4 & 0.035 \\
\hline 16RN265E & ST & $x$ & & & $x$ & $x$ & & $x$ & & & $x$ & & & & $x$ & $x$ & & & & & & & & & \\
\hline $16 \mathrm{RN} 268$ & ST & & $x$ & & $x$ & & $x$ & & & & $x$ & & $x$ & & & & $x$ & 16.8 & 1.6 & 7.4 & 0.1 & 0.0 & 0.2 & 0.37 & 0.004 \\
\hline \multicolumn{26}{|l|}{ Parton } \\
\hline 16RN214B & $\mathrm{CR}$ & & & & & & & & & & $x$ & $x$ & $x$ & $x$ & & $x$ & & 14.8 & 0.8 & 2.3 & 8.4 & 8.8 & 0.7 & 39.1 & 0.020 \\
\hline 16RN214C & $C R$ & & & & & & & & & & $x$ & $x$ & $x$ & & & $x$ & & 11.7 & 2.6 & 8.1 & 2.1 & 2.5 & 0.4 & 18.15 & 0.003 \\
\hline \multicolumn{26}{|l|}{ Eagle } \\
\hline 16RN213A & $\mathrm{CP}$ & & & & & & & $x$ & $x$ & $x$ & & & & & & $x$ & $x$ & 20.9 & 0.2 & 0.7 & 9.7 & 1.3 & 4.3 & 80 & 0.269 \\
\hline 16RN213B & $\mathrm{CP}$ & & & & & & & $x$ & $x$ & & & $x$ & & & & $x$ & $x$ & 18.2 & 0.3 & 1.1 & 13.4 & 0.3 & 1.9 & 25.8 & 0.139 \\
\hline $16 \mathrm{RN} 213 \mathrm{C}$ & $\mathrm{CR}$ & & & & & & & $x$ & $x$ & $x$ & $x$ & $x$ & & & & $x$ & $x$ & 14.1 & 0.4 & 13.3 & 2.7 & 0.5 & 0.1 & 19.9 & 0.075 \\
\hline \multicolumn{26}{|l|}{ Skarn west of Conehead } \\
\hline 16RN142C & CS & & $x$ & & $x$ & & & & & & & & & & & & $x$ & 18.4 & 0.9 & 5.9 & 4.8 & 0.3 & 0.7 & 11.85 & 0.077 \\
\hline \multicolumn{26}{|l|}{ Conehead } \\
\hline 16RN136B & $\mathrm{CP}$ & & & & & & & $x$ & $x$ & & & & $x$ & & & $x$ & $x$ & 27.3 & 0.1 & 0.2 & 0.6 & 0.0 & 0.9 & 3.17 & 0.008 \\
\hline \multicolumn{26}{|l|}{$\mathrm{Nic}$} \\
\hline 16RN210A & $\mathrm{CR}$ & $x$ & & & & & $x$ & & & & $x$ & & & & & & $x$ & 19.7 & 1.4 & 10.7 & 0.0 & 0.0 & 0.1 & 0.3 & 0.003 \\
\hline 16RN211 & $\mathrm{CR}$ & & & & & & & $x$ & & $x$ & & & & & & $x$ & & 10.2 & 0.5 & 9.5 & 5.5 & 4.6 & 0.5 & 26.6 & 0.063 \\
\hline \multicolumn{26}{|l|}{ Ozone } \\
\hline 16RN161A & ST & $x$ & & & $x$ & & $x$ & & & & $x$ & & & & & $x$ & & & & & & & & & \\
\hline 16RN159D & $\mathrm{CP}$ & & & & & & & $x$ & $x$ & & & & $x$ & & & & $x$ & 12.5 & 0.1 & 0.1 & 3.4 & 2.0 & 0.4 & 38.5 & 0.038 \\
\hline 16RN149 & CS & & $x$ & $x$ & & $x$ & $x$ & $x$ & & & $x$ & & & & & $x$ & & & & & & & & & \\
\hline \multicolumn{26}{|l|}{ Wrinkle } \\
\hline 16RN152D & $\mathrm{CP}$ & & & & $x$ & & & $x$ & & $x$ & & & $x$ & & & $x$ & $x$ & 20.4 & 0.1 & 0.4 & 4.4 & 2.8 & 0.2 & 43.8 & 0.056 \\
\hline 16RN156 & $\mathrm{CR}$ & & & & & & & $x$ & & $x$ & $x$ & & & & & $x$ & $x$ & 18.2 & 0.2 & 7.4 & 1.9 & 1.5 & 0.1 & 19.55 & 0.058 \\
\hline 16RN151A & $\mathrm{CP}$ & $x$ & & & & & & $x$ & & & & & & & & $x$ & & 18.4 & 0.1 & 0.1 & 4.6 & 4.2 & 0.1 & 20.6 & 0.038 \\
\hline $16 \mathrm{RN} 152 \mathrm{C}$ & $\mathrm{CR}$ & & & & & & & $x$ & & & & $x$ & $x$ & & & & $x$ & 9.6 & 0.2 & 7.3 & 1.7 & 1.3 & 0.1 & 14.85 & 0.018 \\
\hline \multicolumn{26}{|l|}{ Wrinkle Extension } \\
\hline 16RN158B & $\mathrm{CP}$ & & & & & $x$ & & $x$ & & & & & & & & & $x$ & 30.8 & 0.3 & 0.7 & 0.4 & 0.1 & 0.1 & 4.78 & 0.024 \\
\hline 16RN158D & ST & $x$ & $x$ & & $x$ & $x$ & & & & & $x$ & & & & $x$ & & $x$ & & & & & & & & \\
\hline
\end{tabular}


pyrite, commonly as euhedral grains several millimeters in diameter. Although pyrite is the most visible sulfide (fig. 5), petrographic and XRF work indicate that total base-metal sulfide minerals are often more abundant than pyrite. Based on handheld XRF analyses, sphalerite is always the most abundant basemetal sulfide; galena and chalcopyrite can each be present in trace to percent concentrations.

Individual mineralized bands are typically 3 to $5 \mathrm{~cm}$ wide and separated by 1 to $5 \mathrm{~cm}$ of impure marble. The bands themselves typically comprise equal parts recrystallized calcite, quartz, sheet silicates (chlorite and/or stilpnomelane), and sulfides (fig. 5). Individual sulfide-bearing lenses are traceable for at least $2 \mathrm{~m}$ in outcrop.

\section{Carbonate-poor mineralization}

Approximately half of the sulfidic rocks studied fall into the "carbonate-poor" category (table 1; fig. $6)$. These typically contain subequal parts quartz ( \pm albite), sheet silicates (dominantly chlorite), and sulfides. The iron sulfides include both pyrite (typically coarse and euhedral) and pyrrhotite; the basemetal sulfides are typically dominated by sphalerite, but chalcopyrite can be present at high abundances as well. At the Conehead prospect, the predominant sulfide mineral is pyrrhotite with minor chalcopyrite, trace sphalerite, and negligible galena. Albite appears to be a relatively common minor constituent in the carbonate-poor sulfidic rocks; it is common as large, iron-stained crystals at the Eagle and upper Ozone prospects (e.g., fig. 6 [left]). The carbonate-poor sulfidic rocks may represent complete replacement of original carbonate rock.

Similar to the carbonate-rich sulfidic occurrences, carbonate-poor ones occur as lenses in impure marble. They appear to possess greater strike continuity than the carbonate-rich variety, although we were only able to follow a given layer for about $2 \mathrm{~m}$ along strike. We also have never seen a calcitepoor band turn into a calcite-rich one, nor is the calcite-poor variety necessarily of a higher grade than the calcite-rich type (table 1). It is possible

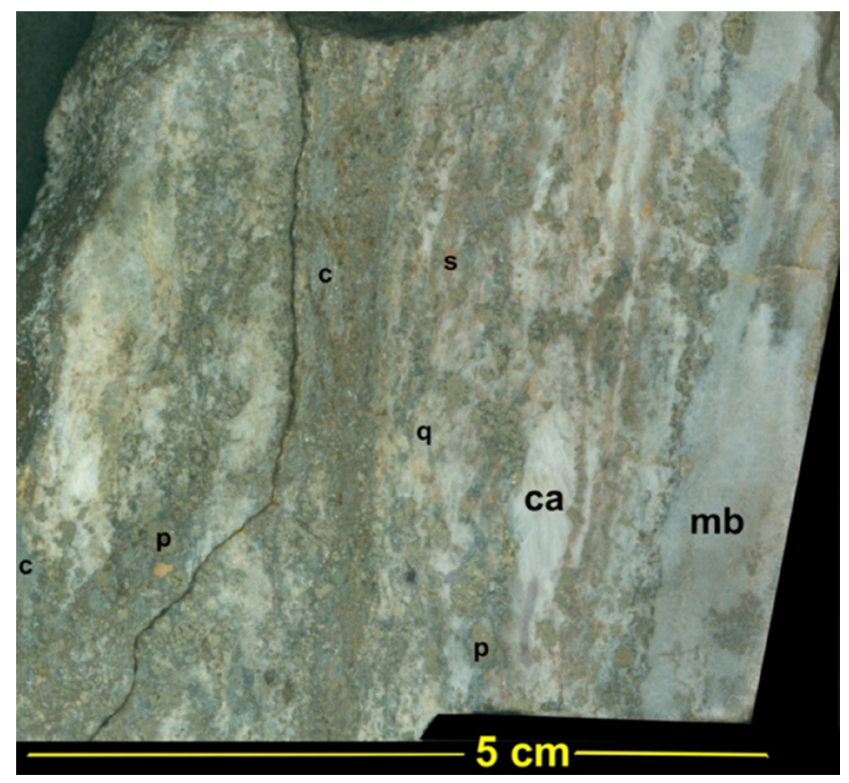

Figure 5. Photograph of typical calcite-rich sulfide mineralization at the Nic prospect (sta. 16RN211). Sulfide-rich bands are in contact with "normal," fine-grained gray marble (mb). The sulfide-bearing bands contain recrystallized calcite (ca), finegrained quartz (q), and irregular masses of chlorite (c). The most visible sulfides are pyrite (p), commonly as 1- to 3-mm-diameter grains, and less visible orange sphalerite (s). Not visible at this scale, galena and chalcopyrite are also present.

that the carbonate-poor occurrences represent a different manner of formation and were not formed by replacement of carbonate sediments.

\section{Calc-silicate-rich mineralization}

Calc-silicate-bearing rocks in the study area are dominated by $\mathrm{Ca}-\mathrm{Fe}$ clinopyroxene, Fe-rich actinolite, stilpnomelane, and a small amount of garnet (fig. 8). Such rocks occur at upper Ozone, Wrinkle Extension, Jacqueline, subcrop west of Conehead (16RN142C), and stations 16MBW178 and 16MBW240. Typically, these rocks are metal poor (upper Ozone, Jacqueline) or contain more pyrrhotite than chalcopyrite (Nic); however, garnet-stilpnomelane skarn with significant sphalerite and galena is present as subcrop west of Conehead (table 1).

\section{Stilpnomelane-rich mineralization}

A small number of sulfidic occurrences fall into the "stilpnomelane-rich" group of greater than about 30 percent stilpnomelane (fig. 9; table 1). 
Usually, the stilpnomelane-rich occurrences contain sparse sulfide. Nearly massive stilpnomelane $( \pm$ Ca-Mn garnet) occurs at the Wrinkle Extension prospect. Stilpnomelane-rich layers occur locally at Jacqueline, Ozone, and with calc-silicate mineralization west of Conehead (fig. 9C, D).

\section{Sulfide mineralogy}

Sulfide minerals observed in polished sections include pyrrhotite, marcasite, pyrite, sphalerite, chalcopyrite, and galena (fig. 10); these minerals are typically intergrown with one another and in some

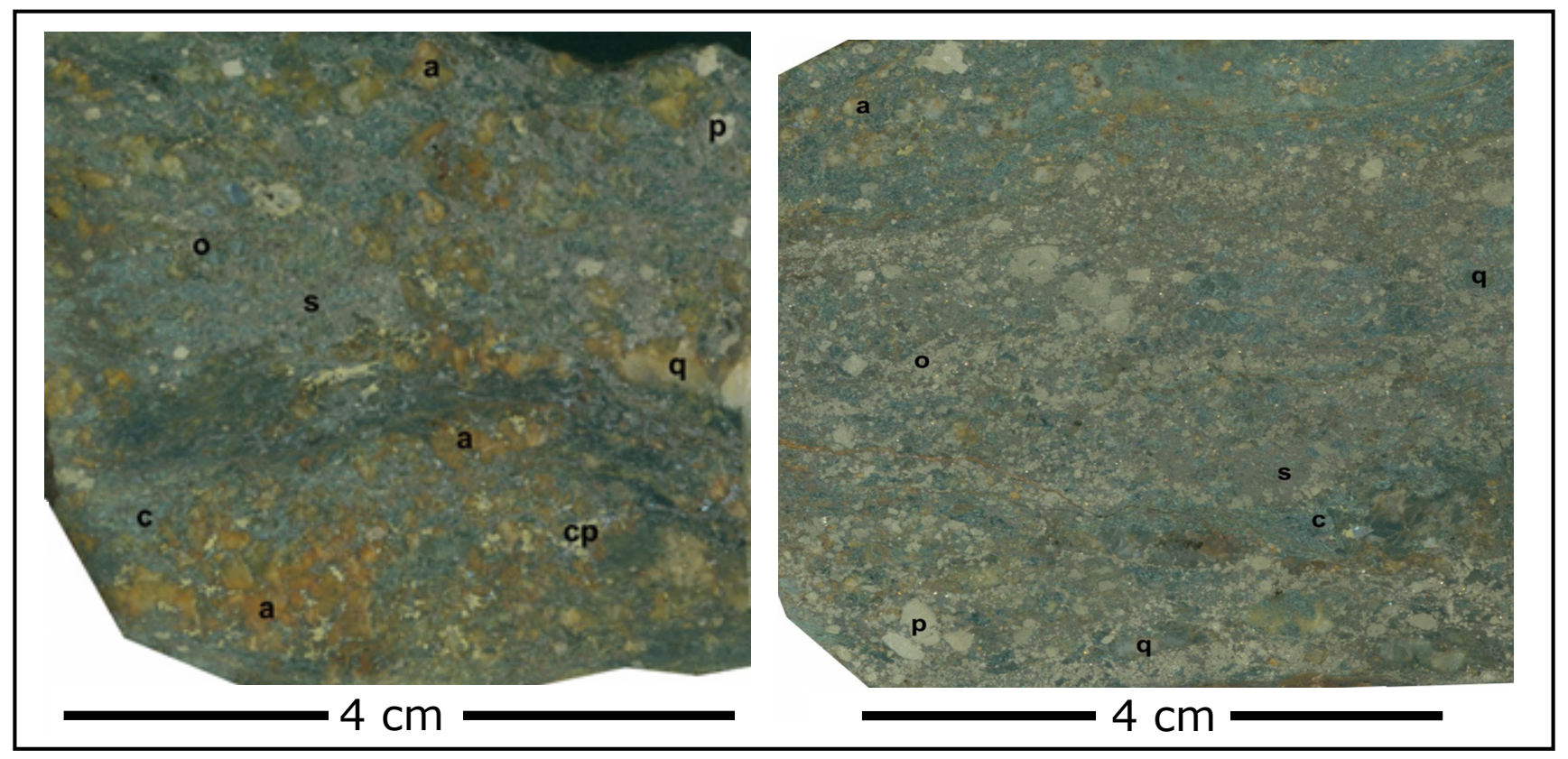

Figure 6. Photographs of calcite-poor sulfidic rocks from the Eagle prospect. Left, 16RN213A, is unusually albite rich with about 30 percent albite, but otherwise typical with about 25 percent total sulfides. Right, 16RN213B, has probably typical calcite-poor mineralization, with about 35 percent total sulfides. Albite (a) and pyrite (p) are present as coarse grains (several millimeters in diameter); pyrrhotite (o), sphalerite (s), and chlorite (c) are finer grained; galena is present but not visible. Chalcopyrite (cp) is especially notable in 16RN213A, intergrown with coarse albite.

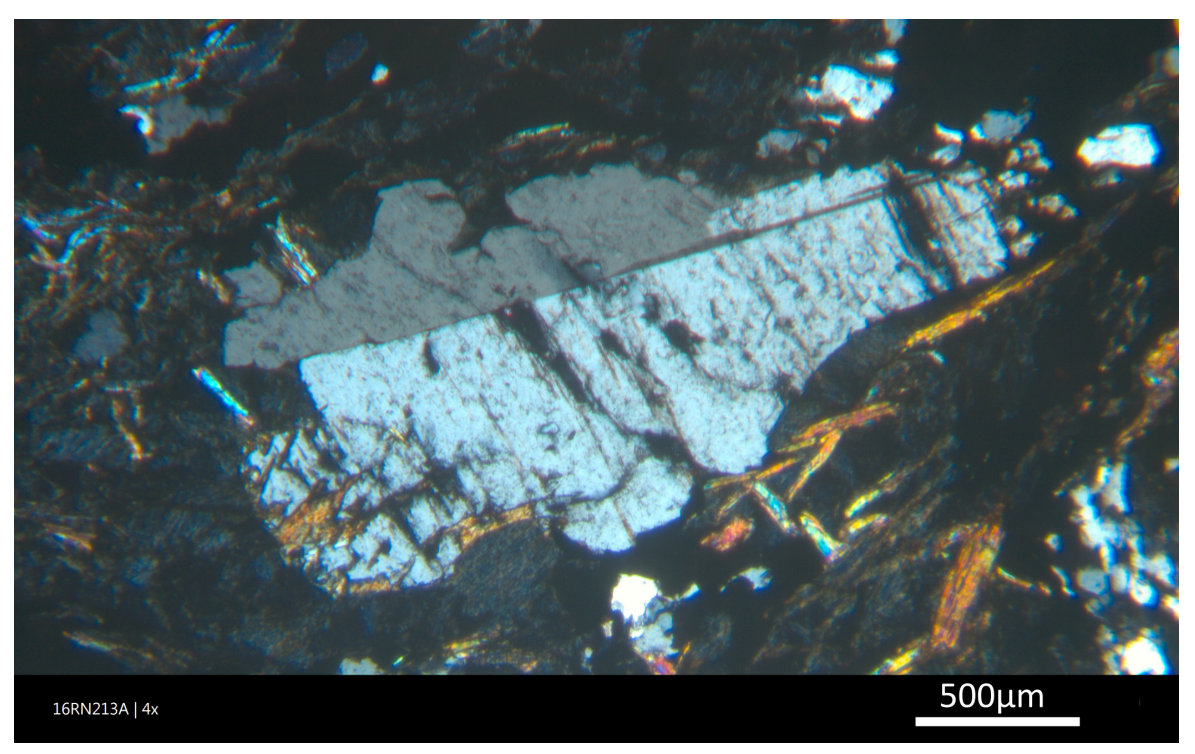

Figure 7. Twinned albite porphyroblast surrounded by white mica and chlorite; crosspolarized light (XPL); Eagle prospect (16RN213A). 

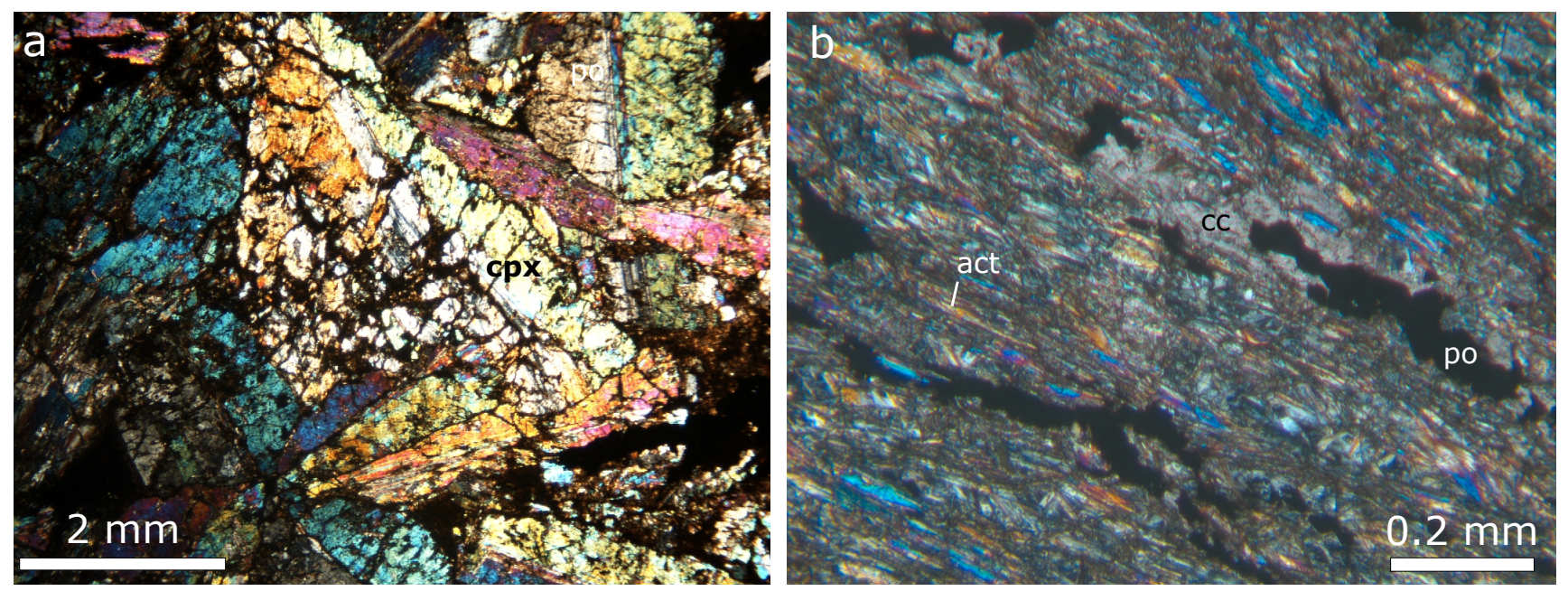

Figure 8. Photomicrographs. A. Coarse-grained clinopyroxene (cpx) from the skarn occurrence west of Conehead (16RN142C); XPL. B. Pyrrhotite (po) bands (opaque) follow metamorphic fabric defined by actinolite (act) with lesser calcite (cc), clinopyroxene, stilpnomelane, and siderite. The latter three minerals were identified by microprobe. Sample from the Jacqueline prospect (16RN268); XPL.
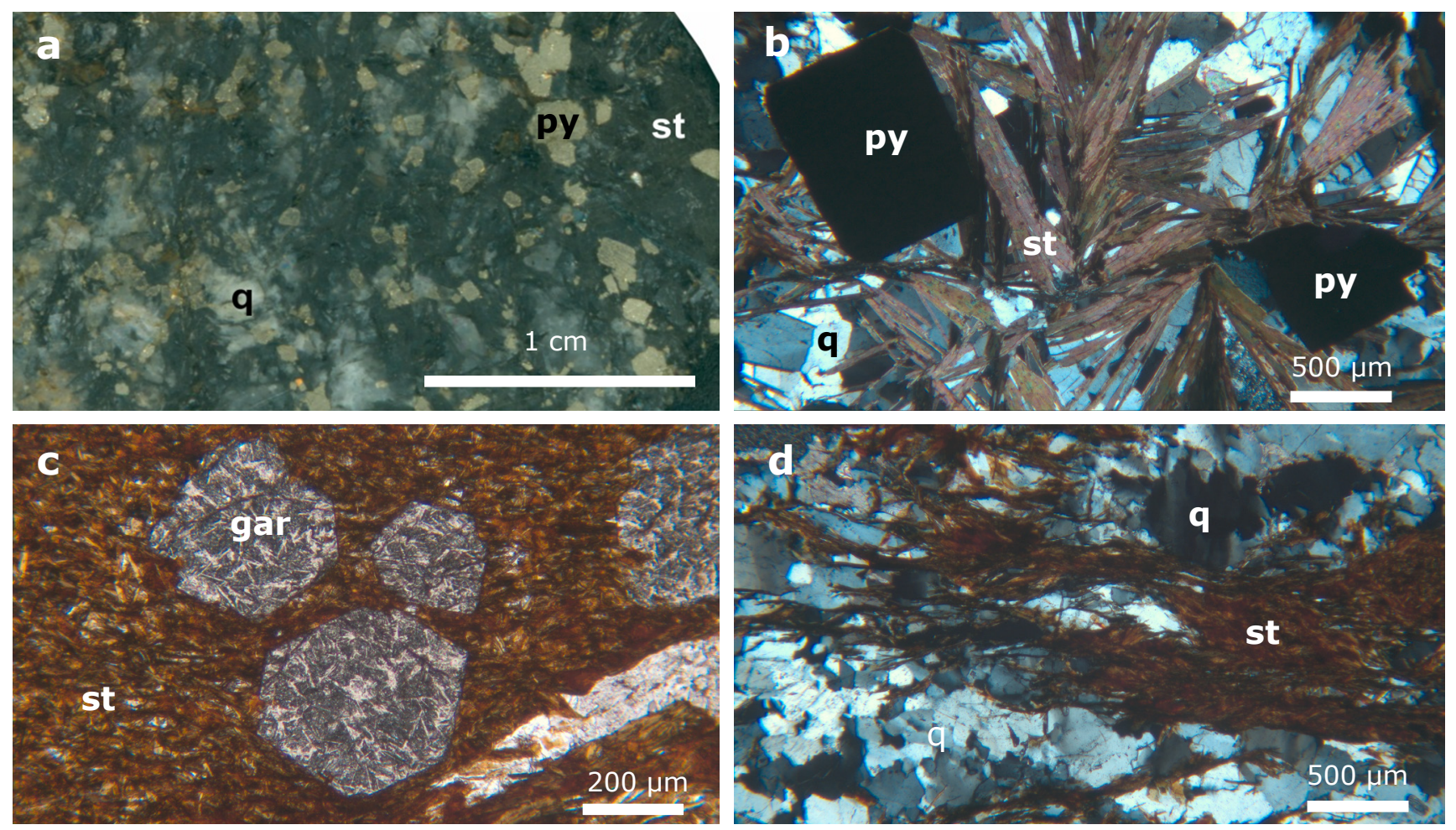

Figure 9. Photomicrographs. A. Coarse-grained pyrite-stilpnomelane-quartz rock (16RN161C) from the lower Ozone prospect. Black stilpnomelane (st) present as radiating black plates occurs with coarse-grained euhedral pyrite (py) and interstitial quartz (q). B. Photomicrograph (XPL) of randomly oriented stilpnomelane, pyrite, and quartz (lower Ozone prospect, 16RN161C). C. Massive stilpnomelane-garnet assemblage; plane-polarized light (PPL). D. Stilpnomelane in apparent metamorphic fabric (XPL); (C) and (D) are from west of Conehead prospect (16RN141A). 
samples form bands parallel to the fabric defined by metamorphic minerals (e.g., fig. 8B). Iron sulfides pyrite and pyrrhotite appear to be early in the paragenetic sequence and show textural evidence for partial replacement by sphalerite, galena, and chalcopyrite. Pyrrhotite is partially replaced by bird's eye marcasite (fig. 10A, B) in most polished sections, which likely reflects supergene processes. We did not observe a consistent paragenesis among sphalerite, chalcopyrite, and galena.

\section{Geology of individual prospects Jacqueline}

At outcrops in the Jacqueline area (fig. 11), at least four thin (less-than-2-m-thick) layers of sulfidebearing impure marble (fig. 12) are interlayered with quartzite and siliceous schist. Scattered mineralized float carrying 2 to 7 percent total base metals
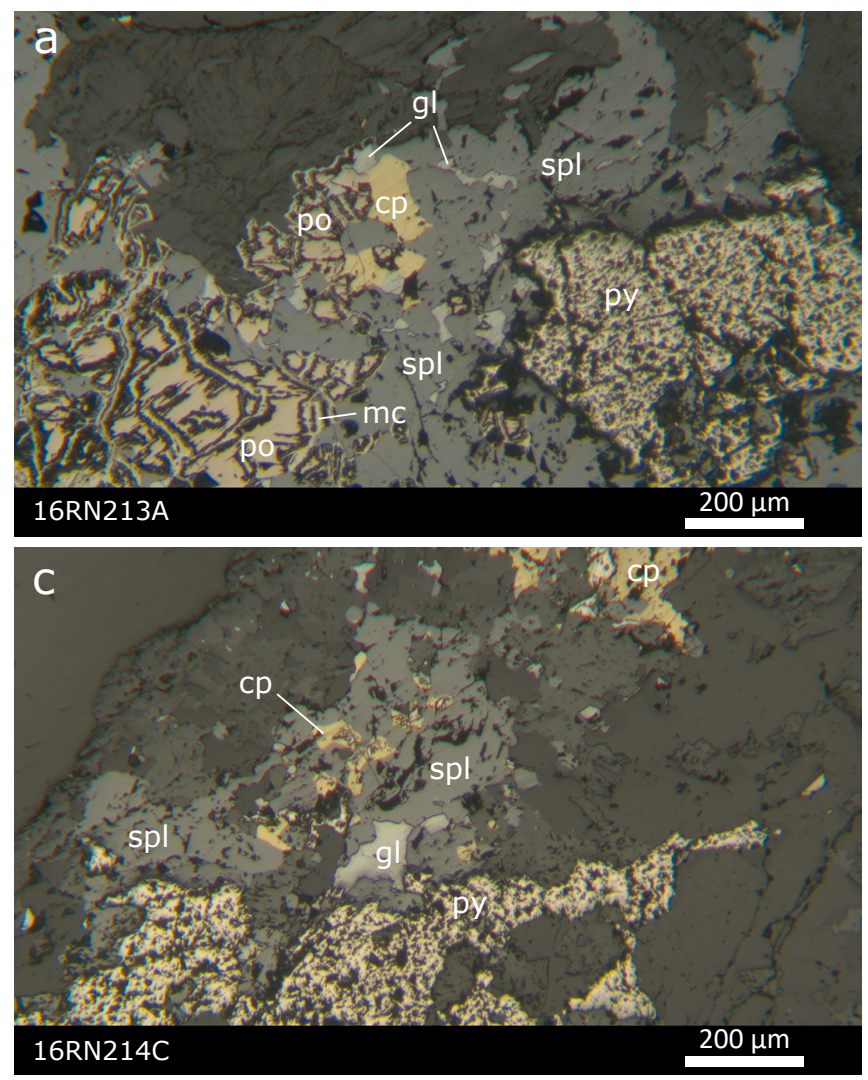

continues along strike, both west and southeast of Jacqueline, indicating discontinuous mineralization occurs along strike about $600 \mathrm{~m}$ to the west and 600 $\mathrm{m}$ to the southeast. Degenhart (1978) suggests continuity of this trend with the Parton prospect to the southeast, extending the length of at least intermittent mineralization to $1,300 \mathrm{~m}$.

The best-mineralized outcrop consists of about $2 \mathrm{~m}$ of impure marble with at least $10 \mathrm{~m}$ of siliceous schist above and below; mineralization consists of four 5-to-12-cm-thick sulfide-bearing bands separated by 20-to-30-cm-thick intervals of impure marble (table 2). One 10-cm-thick band of massive sulfide contains 30 percent pyrrhotite, 3 percent pyrite, 20 percent sphalerite, 0.5 percent chalcopyrite, and trace galena. This material assayed 3.59 percent $\mathrm{Zn}, 0.05$ percent $\mathrm{Pb}, 0.23$ percent $\mathrm{Cu}, 4$ ppm $\mathrm{Ag}$, and $0.035 \mathrm{ppm} \mathrm{Au}$
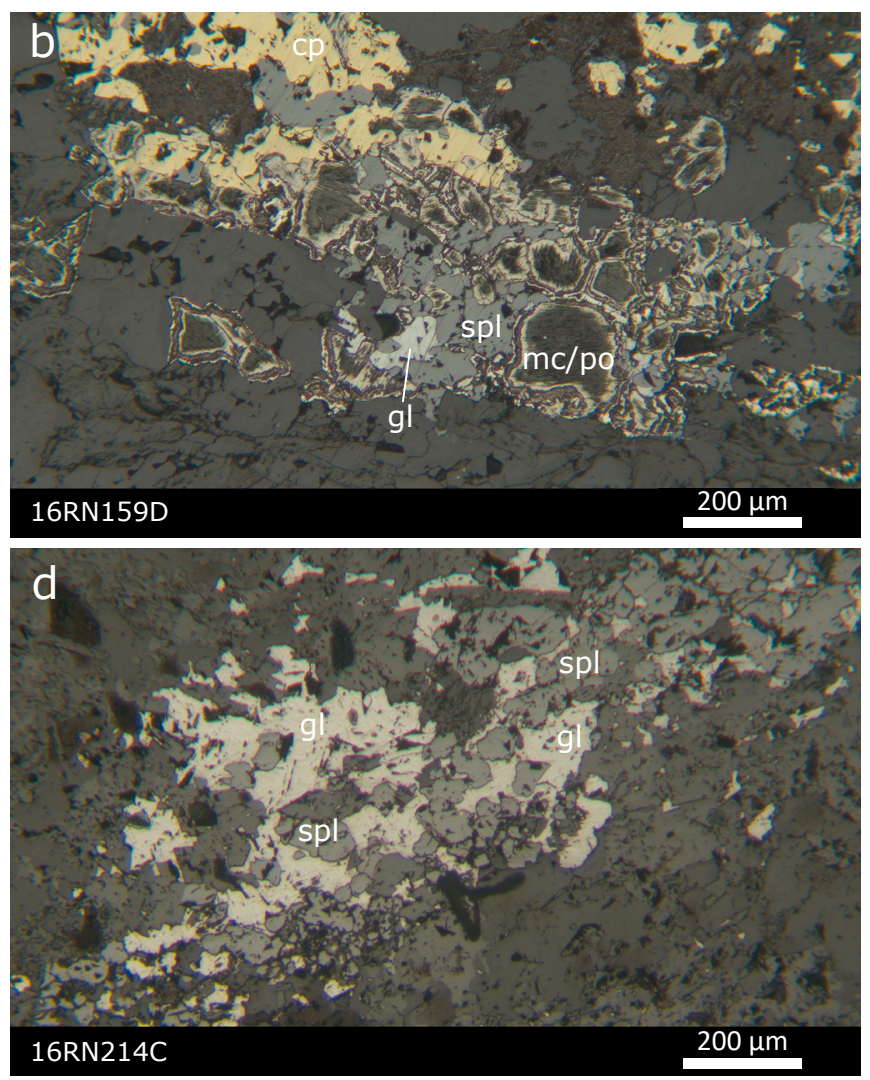

Figure 10. A. Intergrown sphalerite (spl), galena ( $\mathrm{gl}$ ), and chalcopyrite (cp) replace pyrite (py) and pyrrhotite (po; partially altered to marcasite [mc]); Eagle prospect (16RN213A). B. Sphalerite replaces pyrrhotite (marcasite) and galena; chalcopyrite replaces sphalerite and pyrrhotite; upper Ozone prospect (16RN159D). C. Sphalerite replaces pyrite, chalcopyrite, and galena (16RN214C). D. Galena replaces sphalerite in sulfide band; Parton prospect (16RN214C). 
(16RN265D; Wypych and others, 2016). Gangue minerals associated with this mineralization include 20 percent chlorite, 15 percent quartz, and 10 percent actinolite. A second mineralization style (samples 16RN265A, 16RN265E) consists of bands of massive stilpnomelane containing about 3 percent pyrrhotite and 3 percent sphalerite, plus minor calcium-manganese-iron garnet, calcite, chlorite, epidote, and barite. Minor siderite and relict clinopyroxene also occur locally at the prospect.

\section{Parton}

Banded semi-massive sulfides occur within a single marble layer, with the mineralization pinching and swelling from a few inches to up to $1.5 \mathrm{~m}$ (fig. 13). The mineralized marble layer is overlain by quartzite and quartz schist and underlain by muscovite-chlorite-quartz schist. The exposed strike length is at least $61 \mathrm{~m}$ (Degenhart, 1978).

Mineralization consists of pyrite, sphalerite, galena, chalcopyrite, and minor pyrrhotite. It differs from that seen at Eagle and Jacqueline in that it contains relatively high $\mathrm{Pb}(\mathrm{Pb}: \mathrm{Zn}$ ratio around 1.0 ; Wypych and others, 2016). Gangue mineralogy at

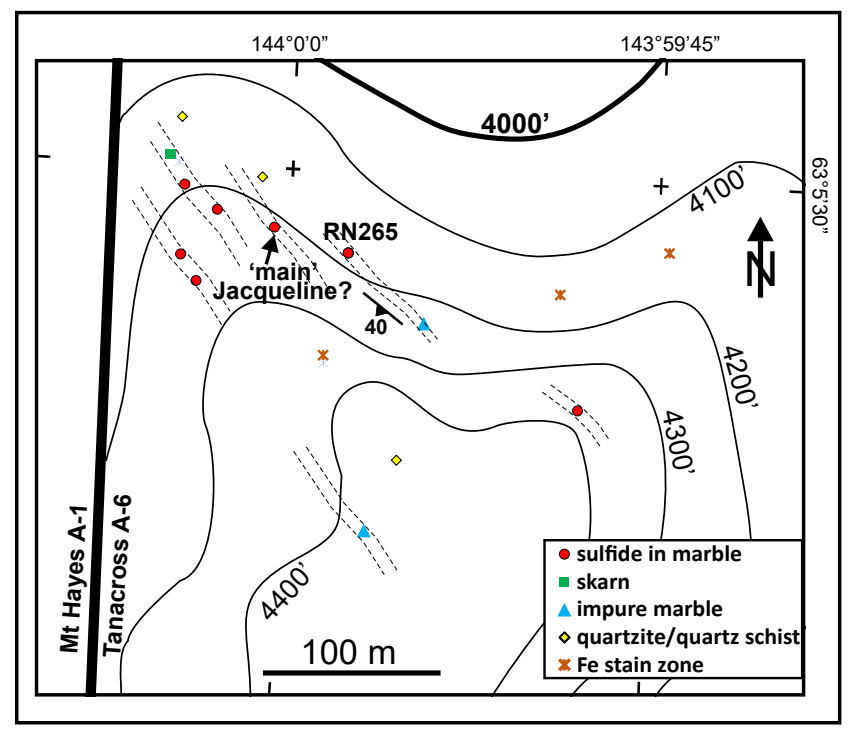

Figure 11. Map showing the distribution of rock types recorded at stations in the vicinity of the Jacqueline prospect. The station identified as "main" Jacqueline best fits the description given in Degenhart (1978). "Skarn" here is used in a non-genetic sense to indicate Ca-Fe-rich silicate mineral assemblage. None of the other sulfide occurrences found are described in Degenhart's report. The marble layers (dashed lines) are each approximately $5 \mathrm{~m}$ thick. The latitude and longitude tick marks are in NAD83 datum, while the Mount Hayes-Tanacross topographic map sheet boundary is defined in NAD27 datum.
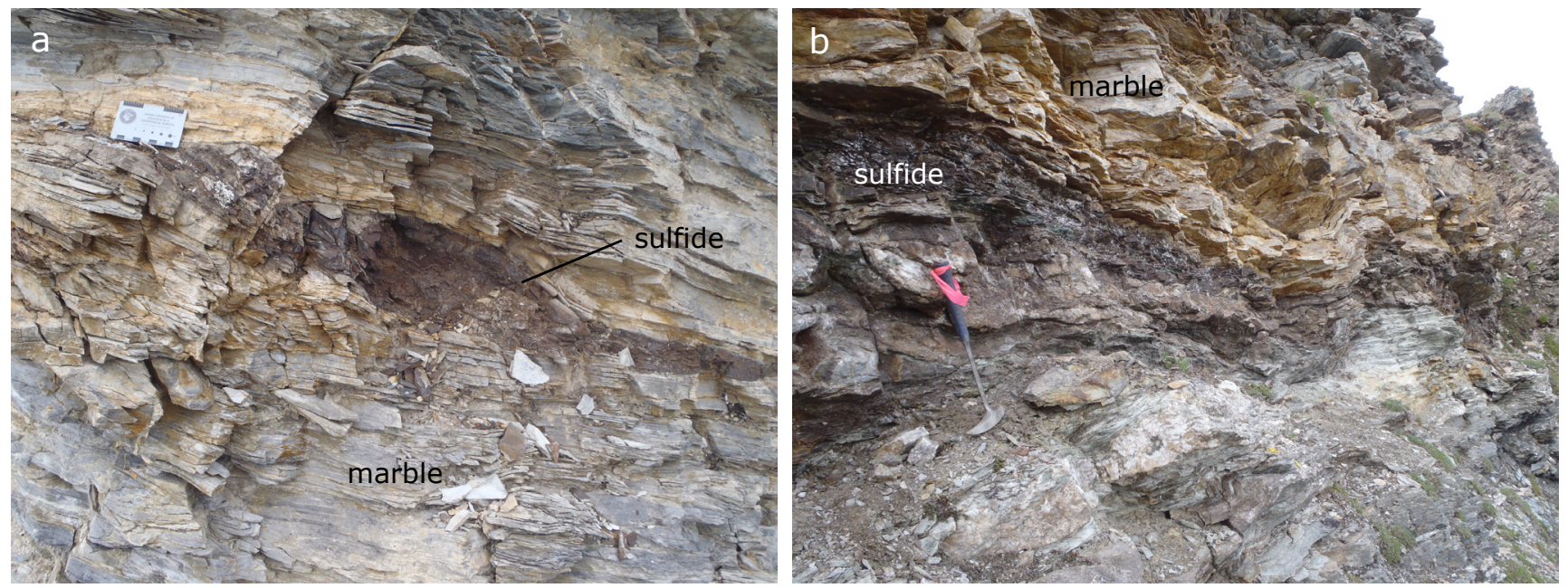

Figure 12. Sulfide mineralization at Jacqueline. A. Sulfide lens in marble. B. 40- to 60-cm-thick band of semi-massive sulfide hosted in marble; exposed along about $20 \mathrm{~m}$ of strike length. A 50 -cm-long crude chip sample across this zone assayed 0.59 percent Zn, 0.49 percent $\mathrm{Cu}$, and 2.9 ppm Ag (sample 16ET502; Wypych and others, 2016). 
Table 2. Layers (from bottom up) present in a marble-rich outcrop, Jacqueline prospect.

\begin{tabular}{|c|l|l|}
\hline $\begin{array}{c}\text { Approximate } \\
\text { thickness }\end{array}$ & \multicolumn{1}{|c|}{ Sample \# } & \multicolumn{1}{c|}{ Description } \\
\hline $20 \mathrm{~cm}$ & & impure marble \\
\hline $10 \mathrm{~cm}$ & $16 \mathrm{RN} 265 \mathrm{D}$ & quartz-pyrrhotite-pyrite-sphalerite-chlorite \\
\hline $30 \mathrm{~cm}$ & & impure marble \\
\hline $12 \mathrm{~cm}$ & $16 \mathrm{RN} 265 \mathrm{C}$ & pyrrhotite-pyrite-quartz-chlorite, minor sphalerite \\
\hline $25 \mathrm{~cm}$ & & impure marble \\
\hline $10 \mathrm{~cm}$ & $16 \mathrm{RN} 265 \mathrm{~B}$ & fine-grained quartz-chlorite lacking sulfide \\
\hline $20 \mathrm{~cm}$ & & impure marble \\
\hline $15 \mathrm{~cm}$ & $16 \mathrm{RN} 265 \mathrm{~A}$ & calcite rich, sulfides + quartz + stilpnomelane \\
\hline $20 \mathrm{~cm}$ & & impure marble \\
\hline $5 \mathrm{~cm}$ & $16 \mathrm{RN} 265 \mathrm{E}$ & stilpnomelane-quartz-sulfides +/- calcite \\
\hline
\end{tabular}

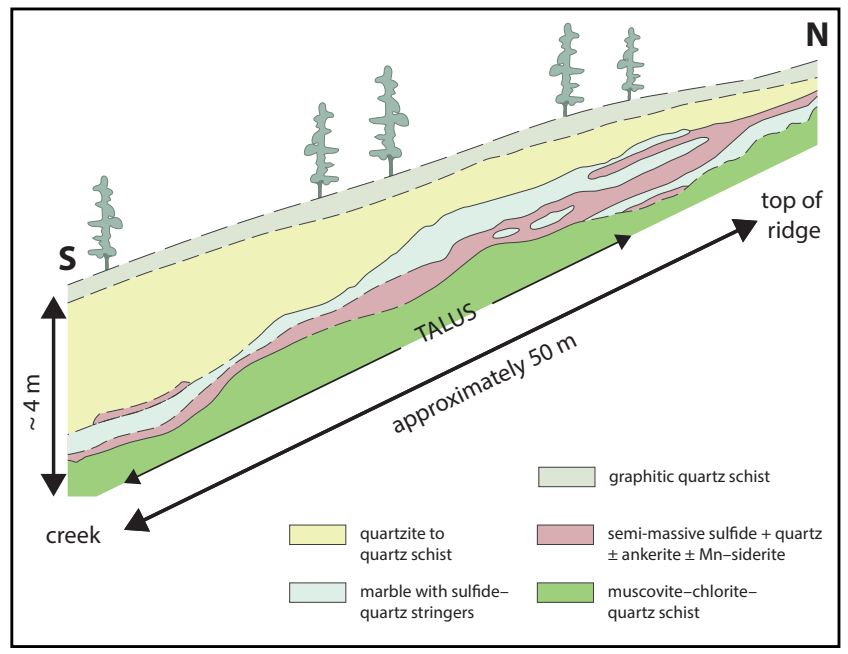

Figure 13. Idealized sketch cross section through the Parton prospect, modified from Degenhart (1978). Vertical exaggeration is approximately $3: 1$. The marble layer is approximately $2 \mathrm{~m}$ thick.

Parton is distinct in that it comprises manganese-rich ankerite, siderite, calcite, and quartz, but lacks silicates like stilpnomelane, chlorite, actinolite, and garnet. Both carbonate-rich and carbonate-poor mineralization is present at Parton (table 1).

Assay highlights include a $1.5-\mathrm{m}$ channel sample averaging 1.35 percent $\mathrm{Cu}, 1.56$ percent $\mathrm{Pb}$, 2.4 percent $\mathrm{Zn}$, and $12.3 \mathrm{ppm} \mathrm{Ag}$, as well as a $0.8-\mathrm{m}$ channel sample assaying 0.61 percent $\mathrm{Cu}, 5.6$ percent $\mathrm{Pb}, 5.8$ percent $\mathrm{Zn}$, and $56.2 \mathrm{ppm} \mathrm{Ag} \mathrm{(Degenhart,}$ 1978). DGGS collected a 1-m chip sample of typical pyrite-rich mineralization that assayed 1.83 percent $\mathrm{Zn}, 1.72$ percent $\mathrm{Pb}, 0.70$ percent $\mathrm{Cu}, 14 \mathrm{ppm} \mathrm{Ag}$, and 0.013 ppm gold (sample 16RN214A of Wypych and others, 2016). A separate, $\mathrm{Cu}$-rich style of mineralization (up to 7.39 percent $\mathrm{Cu}, 0.61$ percent $\mathrm{Pb}$, and 0.87 percent $\mathrm{Zn}$ ) occurs as float in talus and was interpreted by Degenhart (1978) to represent a separate, unexposed mineralized horizon.

\section{Eagle}

Stratabound massive sulfide mineralization partially replaces carbonate within a thin band of white micaceous marble along its upper contact with chloritic and locally talc-bearing siliceous schist. Degenhart (1978) mapped the prospect exposure as an outcrop-scale overturned synform (fig. 14), with the two fold limbs combining for approximately 20 $\mathrm{m}$ of mineralized exposure. The average thickness of sulfide is approximately $1.8 \mathrm{~m}$ (Degenhart, 1978).

Mineralization is 50-80 percent sulfide and dominated by pyrite, with lesser pyrrhotite, sphalerite, chalcopyrite, and galena. Sulfide mineralization is notable in containing as much as 30 percent albite gangue. Chlorite constitutes 10-15 percent and is intergrown with sphalerite. Mineralization is calcite poor, even in close proximity to the contact with the host marble. Overall tenor increases from the overlying schist towards the 
marble contact at the base of sulfides, and the ratio of $\mathrm{Cu}$ and $\mathrm{Zn}$ to $\mathrm{Pb}$ increases with proximity to the marble (Degenhart, 1978).

Sampling by DGGS in 2016 indicates three subtypes of mineralization are represented in the boulder float at the Eagle prospect. Pyritic mineralization makes up about half of the observed mineralization, containing 40 percent pyrite and assaying 9.72 percent $\mathrm{Zn}, 1.28$ percent $\mathrm{Pb}, 4.33$ percent $\mathrm{Cu}$, $80 \mathrm{ppm} \mathrm{Ag}$, and $0.269 \mathrm{ppm}$ gold (16RN213A; Wypych and others, 2016). Sphalerite-rich mineralization contains 20 percent pyrite, with 13.35 percent $\mathrm{Zn}, 0.29$ percent $\mathrm{Pb}, 1.93$ percent $\mathrm{Cu}, 25.8$ ppm Ag, and 0.139 ppm gold (16RN213B; Wypych and others, 2016). About 10 percent of the observed mineralization contains ankerite, sulfides, and quartz apparently replacing marble. This type of mineralization assayed 2.65 percent $\mathrm{Zn}, 0.46$ percent $\mathrm{Pb}$, 0.14 percent $\mathrm{Cu}, 19.9 \mathrm{ppm} \mathrm{Ag}$, and $0.075 \mathrm{ppm}$ gold (16RN213C; Wypych and others, 2016).

\section{Calc-silicate-rich occurrence west of Conehead}

Sulfide-mineralized skarn-like assemblages, including clinopyroxene and massive stilpnomelanegarnet, occur along the Eagle trend $500 \mathrm{~m}$ west of Conehead and 1,100 m southeast of the Eagle prospect (see app. for prospect locations). This occurrence is found in subcrop over an area of approximately $20 \mathrm{~m}$ by $50 \mathrm{~m}$.

Mineralization is characterized as disseminated to wispy sulfides, including sphalerite, galena, pyrrhotite, pyrite, and chalcopyrite. Specular hematite is present locally in stilpnomelane-garnet rock. This occurrence is significant in its preservation of a skarn-like assemblage, including clinopyroxene, which is rarely observed elsewhere in the Eagle trend due to retrograde alteration and metamorphism. The clinopyroxene is iron rich, approximately 19 -mole percent johannsenite, 22-mole percent diopside, and 59 mole-percent hedenbergite (microprobe data are presented in a later section of this report).

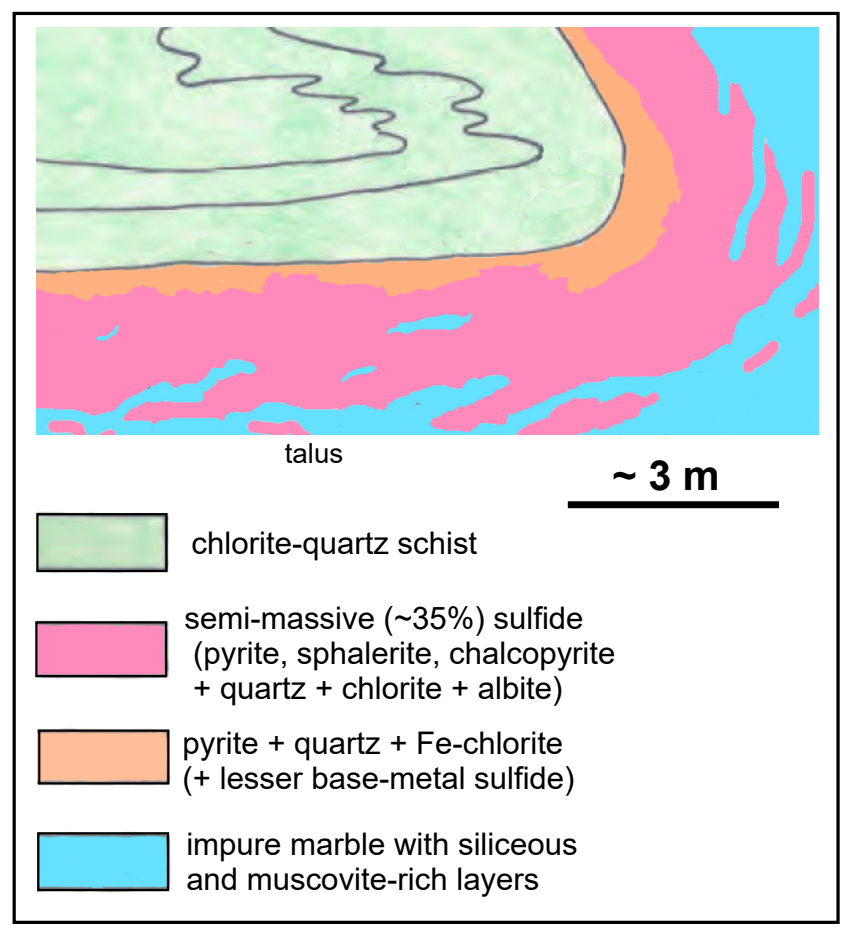

Figure 14. Highly idealized sketch of a cliff face at the Eagle prospect, modified from Degenhart (1978) on the basis of talus boulder inspections.

Garnet at the occurrence is manganese rich, similar to other garnets at prospects in the Eagle trend.

A select sample of clinopyroxene-rich material collected by DGGS assayed 4.72 percent $\mathrm{Zn}, 3.28$ percent $\mathrm{Pb}, 0.03$ percent $\mathrm{Cu}, 148 \mathrm{ppm} \mathrm{Ag}$, and 0.548 ppm gold (16RN142B; Wypych and others, 2016). Other results include a sample that yielded 4.84 percent $\mathrm{Zn}, 0.28$ percent $\mathrm{Pb}, 0.66$ percent $\mathrm{Cu}$, $11.85 \mathrm{ppm} \mathrm{Ag}$, and $0.077 \mathrm{ppm} \mathrm{Au}$, and another sample containing 0.55 percent $\mathrm{Zn}$ (16RN142C; Wypych and others, 2016).

\section{Conehead}

As described by Degenhart (1978), the prospect consists of scattered pyrrhotite-rich sulfide bands (fig. 15), generally around $30 \mathrm{~cm}$ thick, hosted by a 30 -ft-thick light-green laminated siliceous rock that is overlain by gray to green quartz-sericite schist and underlain by gray to black quartz-mica schist. The mineralization is traceable for approximately 

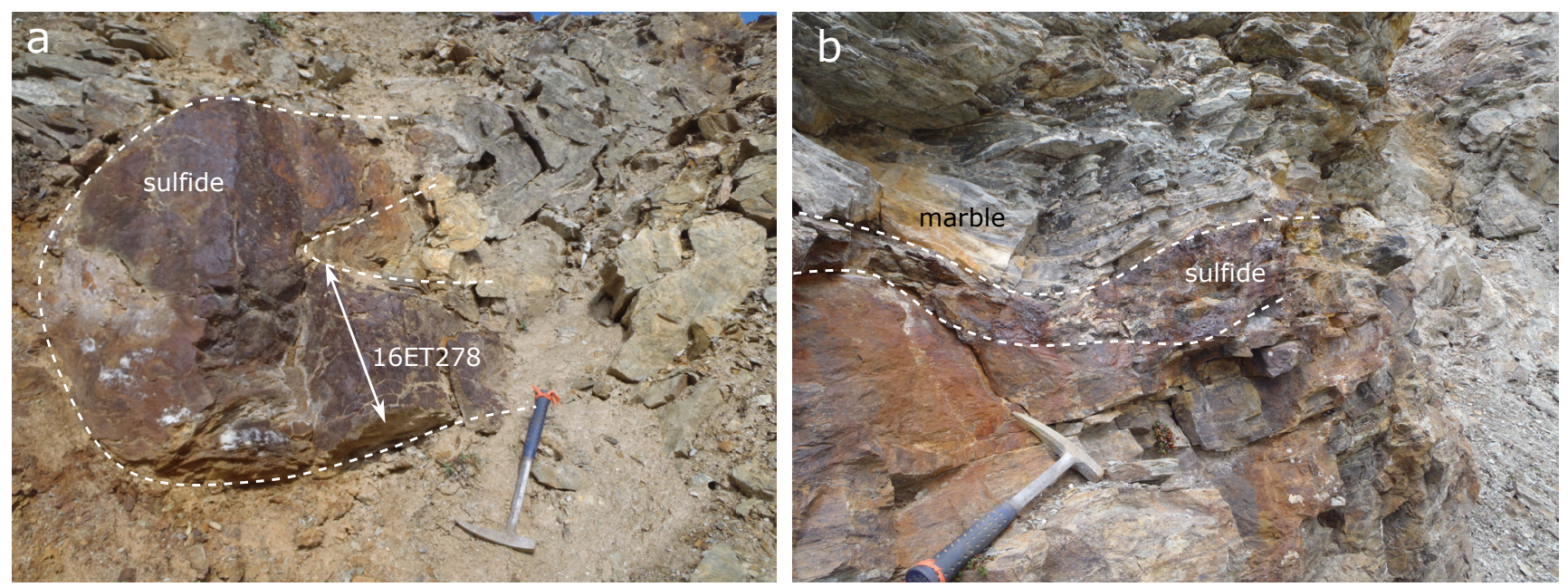

Figure 15. Massive sulfide mineralization at the Conehead prospect. A. A tightly folded massive sulfide lens at sample site 16ET278 (Wypych and others, 2016). Hammer is $40 \mathrm{~cm}$ in length. B. Irregular massive sulfide lens 5 to $40 \mathrm{~cm}$ thick at sample site 16ET281 (Wypych and others, 2016).

$38 \mathrm{~m}$ and is terminated at both ends by east-westtrending shear zones.

The mineralogy of the sulfide bands is pyrrhotite (up to 70 percent) with minor pyrite, chalcopyrite, sphalerite, and trace galena. Gangue minerals include quartz (about 25 percent), with minor albite, siderite, and chlorite.

Marble is less commonly observed with mineralization at the Conehead prospect, as compared to the other prospects of the Eagle trend. However, we observed a $10-\mathrm{cm}$-thick layer of marble in the immediate hanging wall of one massive sulfide lens, and the mineralogy and trace-element geochemistry are similar to that of calcite-poor mineralization elsewhere in the Eagle trend.

Of the six channel samples collected by WGM Inc. in 1978, none contained more than 1.5 percent combined base metals (Degenhart, 1978). Sampling by DGGS in 2016 included a 40-cm chip sample across one massive pyrrhotite band that assayed 0.78 percent $\mathrm{Zn}, 0.34$ percent $\mathrm{Cu}$, and $4.58 \mathrm{ppm} \mathrm{Ag}$ (fig. 15A; 16ET278; Wypych and others, 2016), while a select sample of massive sulfide contained 2.61 percent $\mathrm{Zn}, 0.02$ percent $\mathrm{Pb}, 1.56$ percent $\mathrm{Cu}, 4.66$ ppm Ag, and 0.06 ppm Au (fig. 15B; 16ET281; Wypych and others, 2016).

\section{Nic}

The Nic prospect consists of at least four separate, approximately 1 -m-thick sulfide-bearing layers, surrounded by talus, on a south-facing slope (fig. 16). Layering dips moderately (about 35 degrees) to the southwest, and the westernmost (highest) body is about $100 \mathrm{~m}$ west of the lowest one. The mineralization may represent replacement of carbonate in several different impure marble layers separated by quartz schist talus.

The central outcrop is a 1.2 -m-thick impure marble layer containing 12 -mm-thick sulfide bands spaced 3 to $5 \mathrm{~cm}$ apart (fig. 16B). The pyrite is coarse-grained and euhedral to subhedral; the other sulfides are smaller and not particularly associated with the pyrite. The exposure measures approximately $6 \mathrm{~m}$ long. A 50 -cm chip sample across the layer collected by DGGS assayed 5.45 percent $\mathrm{Zn}$, 4.62 percent $\mathrm{Pb}, 0.45$ percent $\mathrm{Cu}, 26.6 \mathrm{ppm} \mathrm{Ag}$, and $63 \mathrm{ppb} \mathrm{Au}$ (16RN211; Wypych and others, 2016). A 1.2-m chip sample by WGM Inc. assayed 3.65 percent $\mathrm{Pb}, 3.65$ percent $\mathrm{Zn}, 0.51$ percent $\mathrm{Cu}$, $22 \mathrm{ppm} \mathrm{Ag}$, and $35 \mathrm{ppb} A u$ (Degenhart, 1978). 
Figure 16. Sketch map of the Nic prospect showing the three different types of sulfide occurrences spread out over approximately $150 \mathrm{~m}$. These seem to represent three different and separated impure marble bodies. The

zone of most intense Fe staining is completely separate from the sulfiderich prospects. The schistosity shown is an average of several measurements in the area. Insets are map view. Marble is colored blue; sulfide is colored red or orange; sulfide-chlorite-quartz is colored pink; actinolite-pyroxene rock is colored green.

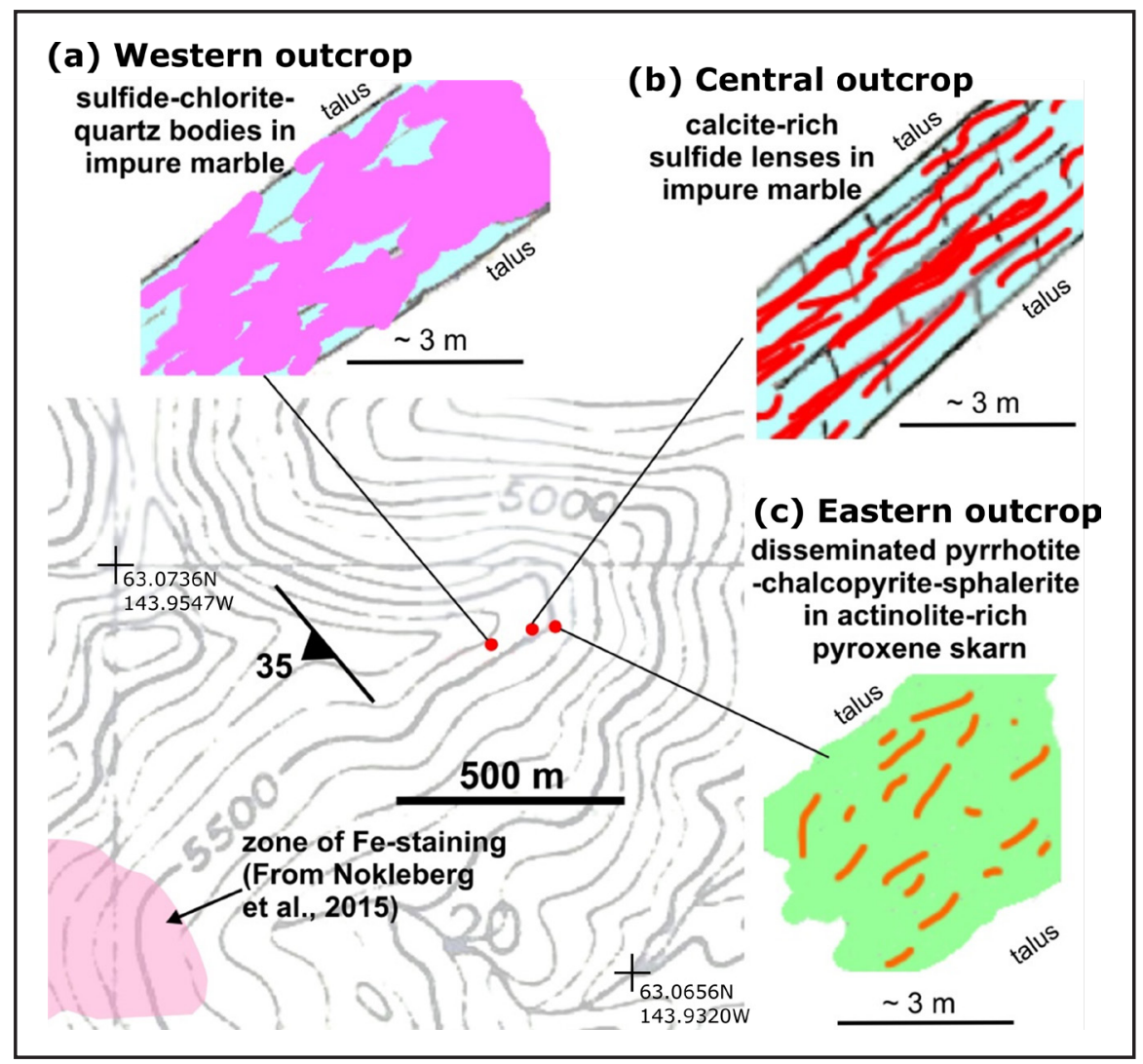

Another mineralized exposure is about $1 \mathrm{~m}$ thick and located $20 \mathrm{~m}$ east of the central outcrop (fig. 16C). It is primarily actinolite, with lesser stilpnomelane and garnet. It contains a few percent disseminated pyrrhotite with minor chalcopyrite and sphalerite. A sample of this material assayed 0.12 percent $\mathrm{Cu}$ (16RN210; Wypych and others, 2016).

Another layer, described by Degenhart (1978) and not relocated by DGGS, is approximately 30 $\mathrm{cm}$ thick and lies $30 \mathrm{~m}$ stratigraphically below the central outcrop. This consists of chalcopyrite, sphalerite, and pyrite in gray to black quartzose, graphitic mica schist. A sample across this zone assays 3.03 percent $\mathrm{Cu}, 0.32$ percent $\mathrm{Zn}, 10.3 \mathrm{ppm}$ $\mathrm{Ag}$, and 3,720 ppb mercury.

The westernmost outcrop, about $85 \mathrm{~m}$ west of the central outcrop, is blocky sulfide-chloritequartz rock (fig. 16A). It differs from most calcitepoor mineralization in that it lacks pyrrhotite and contains millimeter-scale chlorite-rich and sulfide-rich bands. Impure marble is locally present. A $30-\mathrm{cm}$ chip sample of this material assayed 0.13 percent $\mathrm{Cu}$ and 0.125 ppm Au (16RN212A; Wypych and others, 2016).

\section{Ozone}

As described by Degenhart (1978), the Ozone occurrence contains stratabound massive to semi-massive sulfide pods and areas of gossan visible along a strike length of approximately $450 \mathrm{~m}$; taking into account folding and faulting, Degenhart (1978) interprets the occurrence to occupy the same stratigraphic horizon as the Wrinkle and Wrinkle Extension occurrences. Field observations by DGGS geologists indicate that the Ozone occurrence consists of at least three marble-hosted bodies of varying style and mineralogy; their geometry indicates either three separate layers or one complexly folded layer.

At the best-mineralized outcrop, lenses of quartz-sulfide rock total $65 \mathrm{~cm}$ within an approximately 4-m-thick marble layer. Sulfides total 5 to 20 
percent and are either pyrite rich or pyrrhotite rich, and also include sphalerite, galena, and chalcopyrite. Gangue minerals include 50 to 80 percent quartz and lesser amounts of chlorite and albite. A $20-\mathrm{cm}$ band representative of this material assayed 3.69 percent $\mathrm{Zn}, 0.18$ percent $\mathrm{Pb}, 1.44$ percent $\mathrm{Cu}$, and 8.26 ppm Ag (sample 16RN159A of Wypych and others, 2016); another 20-cm band from this outcrop assayed 0.316 percent $\mathrm{Zn}, 2.33$ percent $\mathrm{Pb}, 0.096$ percent $\mathrm{Cu}$, and 28.9 ppm Ag (16RN159C; Wypych and others, 2016). A 15-cm band of sulfide mineralization from an outcrop $120 \mathrm{~m}$ to the east assayed 1.305 percent $\mathrm{Zn}, 1.955$ percent $\mathrm{Pb}, 0.16 \mathrm{ppm} \mathrm{Cu}$, and $7.87 \mathrm{ppm} \mathrm{Ag}$ (16RN161A; Wypych and others, 2016). No Au assays exceeded 0.06 ppm.

Other layers at Ozone include a barren zone of skarn-like garnet-pyroxene-actinolite rock, and one of quartz-stilpnomelane-calcite-albite rock carrying 5 percent pyrite and trace chalcopyrite.

\section{Wrinkle}

Stratabound massive to semi-massive sulfide mineralization occurs within a layer of impure marble exposed over a length of $190 \mathrm{~m}$; mineralization may be up to $4.6 \mathrm{~m}$ thick but averages about $2 \mathrm{~m}$ thick (Degenhart, 1978). The mineralization includes both irregular and lens-like layers in marble (fig. 17). Sulfides constitute approximately 50 percent of the marble band, and individual sulfide bodies are up to about $0.8 \mathrm{~m}$ thick. The exposed mineralization continues to the east until covered by talus; mineralization appears to gradually end to the west despite the continuation of the marble layer.

At the thickest exposure, a 4.6-m chip sample by WGM Inc. across approximately $4.3 \mathrm{~m}$ of sulfides and $30 \mathrm{~cm}$ of marble assayed 0.19 percent $\mathrm{Cu}, 1.16$ percent $\mathrm{Pb}, 1.89$ percent $\mathrm{Zn}, 14 \mathrm{ppm} \mathrm{Ag}$, $0.1 \mathrm{ppm} \mathrm{Au}, 0.02$ percent $\mathrm{Bi}$, and 0.01 percent Co. Sampling throughout the outcrop indicates an average grade of 2.5 percent combined base metals (Degenhart, 1978).

Most mineralization at Wrinkle is calcite-poor quartz-chlorite-sulfide lenses in marble. Coarse (greater-than-1-mm) porphyroblastic pyrite is ubiquitous, along with variable amounts of fine-grained pyrrhotite. Sphalerite and galena are more abundant than chalcopyrite. Quartz, iron-rich chlorite, stilpnomelane, garnet, magnesian ankerite, and magnesian siderite are gangue minerals (mineral compositions were determined by microprobe). A sample of this mineralization assayed 4.41 percent $\mathrm{Zn}, 2.77$ percent $\mathrm{Pb}, 0.15$ percent $\mathrm{Cu}, 43.8 \mathrm{ppm} \mathrm{Ag}$, and $0.056 \mathrm{ppm}$ $\mathrm{Au}$ (16RN152D; Wypych and others, 2016).

A second, less common type of mineralization is calcite rich and contains less pyrrhotite and generally lower base-metal concentrations; one such

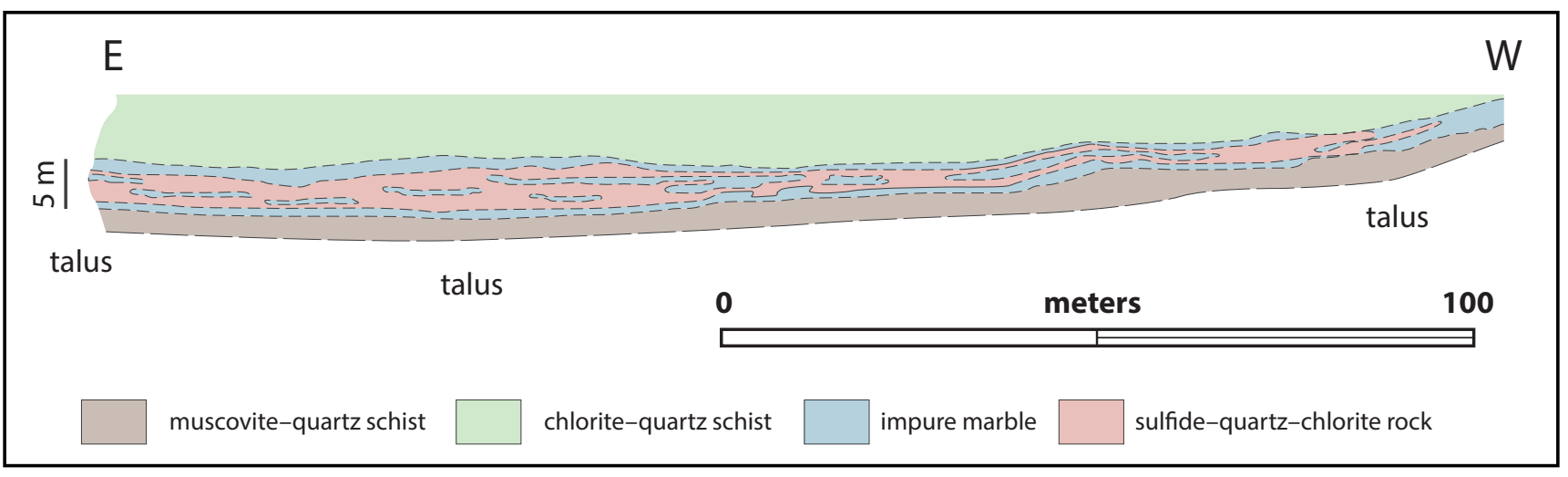

Figure 17. Generalized sketch of the Wrinkle prospect outcrop, modified from Degenhart (1978). The host impure marble appears to taper slightly from east (E) to west (W); sulfidic rocks gradually taper out to the west. 
sample assayed 1.85 percent $\mathrm{Zn}, 1.47$ percent $\mathrm{Pb}$, 0.1 percent $\mathrm{Cu}, 19.6 \mathrm{ppm} \mathrm{Ag}$, and $0.058 \mathrm{ppm} \mathrm{Au}$ (16RN156; Wypych and others, 2016).

\section{Wrinkle Extension}

A semi-continuous layer of pyrrhotite-rich, base-metal-poor massive sulfide is 5 to $50 \mathrm{~cm}$ thick and traceable over a distance of approximately 100 $\mathrm{m}$. This sulfide layer is tightly folded and generally parallels the outcrop surface, resulting in a large gossanous exposure and fold repetition of the mineralized horizon. The mineralization and accompanying calc-silicate minerals appear to be replacements of impure carbonate, though less than 10 percent marble is present at the exposure.

Sulfide occurs as massive to semi-massive bands at the contact between the overlying quartzite and a dark-green to black rock composed of 85 percent stilpnomelane, 10 percent manganese-rich garnet, and 5 percent calcite (fig. 18). The mineralization consists of 35-50 percent pyrrhotite and only minor sphalerite, galena, and chalcopyrite, and is accompanied by chlorite-quartz gangue; one sample of the massive sulfide mineralization assayed 0.38 percent $\mathrm{Zn}, 0.09$ percent $\mathrm{Pb}, 0.07$ percent $\mathrm{Cu}$, $4.78 \mathrm{ppm} \mathrm{Ag}, 0.024 \mathrm{ppm} \mathrm{Au}$, and 30.8 percent $\mathrm{Fe}$ (16RN158B; Wypych and others, 2016).

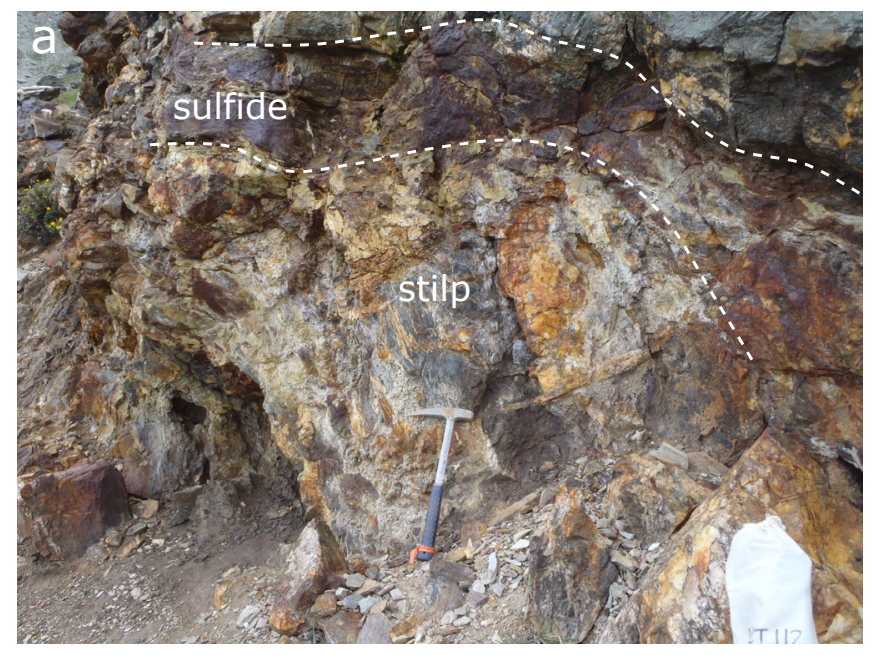

\section{Ore and trace elements}

Base-metal assays from Tanacross A-6 prospects indicate a wide range of $\mathrm{Cu}: \mathrm{Pb}: \mathrm{Zn}$ ratios (fig. 19). There are two basic clusters: $\mathrm{Zn}$-Cu-type samples that have low $\mathrm{Pb}$ and a wide range of $\mathrm{Zn}: \mathrm{Cu}$ ratios, and $\mathrm{Zn}$-Pb-type samples that have subequal $\mathrm{Zn}$ and $\mathrm{Pb}$ and little $\mathrm{Cu}$. The Wrinkle and Parton prospects contain mostly $\mathrm{Zn}-\mathrm{Pb}$ mineralization. Calc-silicate-associated mineralization west of Conehead, at Conehead proper, Eagle, and Wrinkle Extension are $\mathrm{Pb}$-poor occurrences. Nic and Jacqueline, which have multiple mineralized layers and are the most diverse in terms of gangue mineralogy, include samples in both the $\mathrm{Zn}-\mathrm{Cu}$ and $\mathrm{Zn}-\mathrm{Pb}$ clusters. $\mathrm{Zn}: \mathrm{Pb}: \mathrm{Cu}$ ratios do not seem to vary according to gangue mineralogy (e.g., table 1), nor do they suggest a robust pattern of metal zonation at map scale, such as a difference between the Eagle trend and the Wrinkle and Ozone prospects.

Prospect-wide averaged data from the PP-LZ trend (PP and LZ East) plot with the $\mathrm{Zn}-\mathrm{Pb}$ cluster, while averaged data from the Delta mineral belt VMS prospects (DW, LP, MID, PP2, Nunatak, HD South, HD North, DD South, DD North) show compositions near the $\mathrm{Zn}-\mathrm{Pb}$ cluster (fig. 19; S. Dashevsky, written commun., 2016).

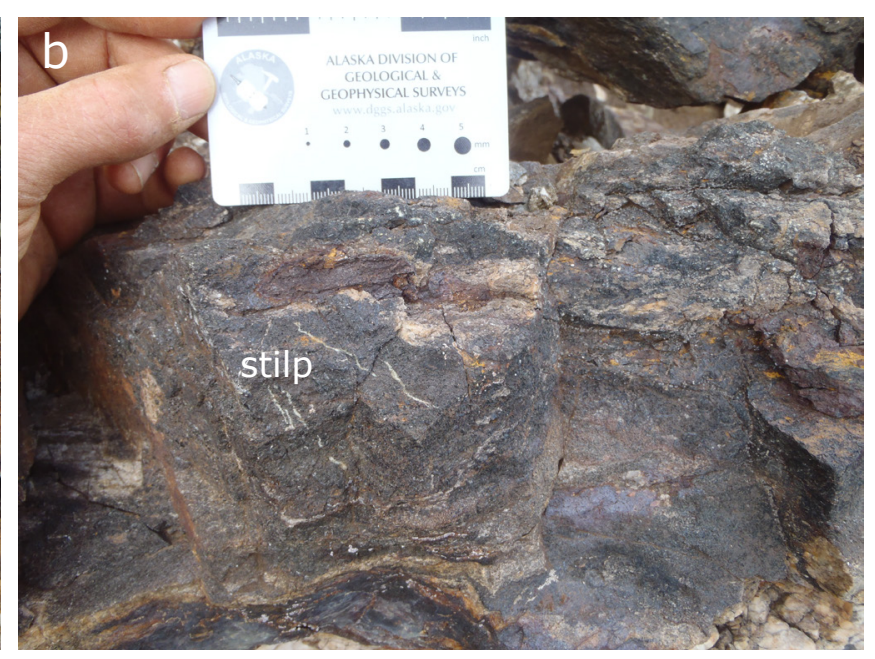

Figure 18. Photos of the Wrinkle Extension prospect. A. Iron-rich massive sulfide band with stilpnomelane-garnet rock in the footwall. Hammer is $40 \mathrm{~cm}$ for scale. B. Close-up view of stilpnomelane-garnet rock with sulfide veinlets. 
Samples from the Tanacross A-6 base-metal deposits containing more than 0.5 percent $\mathrm{Zn}$ have relatively consistent $\mathrm{Zn}: \mathrm{Cd}$ ratios ranging from 213

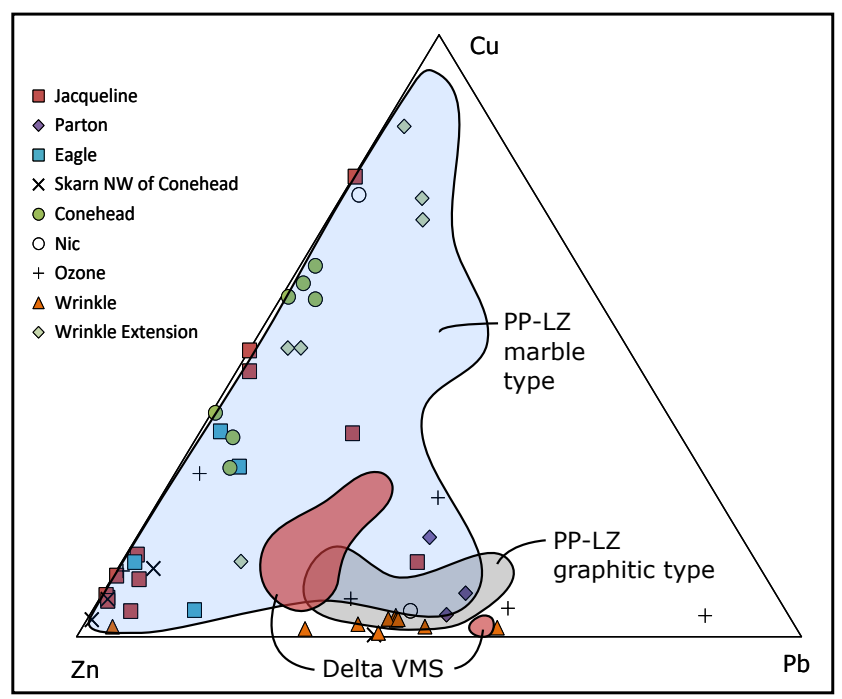

Figure 19. Ternary diagram showing relative proportions of $\mathrm{Zn}, \mathrm{Pb}$, and Cu for base-metal prospects in the Tok River area. PP-LZ data are from Culp (1982); Delta district VMS data are averages by prospect calculated from industry drilling and sampling (S. Dashevsky, written commun., 2016); individual samples are shown for the various base-metal prospects of the Tanacross A-6 Quadrangle (Wypych and others, 2016). to 377 and averaging 297 (fig. 20A; Wypych and others, 2016). Data from the PP-LZ trend indicate an average $\mathrm{Zn}: \mathrm{Cd}$ ratio around 296; averages from the Delta mineral belt are distinctly higher, ranging from 427 to 656 and averaging 544 (S. Dashevsky, written commun., 2016).

Comparison of Tanacross A-6 base-metal prospects indicates concentrations of As up to $252 \mathrm{ppm}$ and $\mathrm{Sb}$ up to $53.5 \mathrm{ppm}$ (excluding one anomalous sample; fig. 20B; Wypych and others, 2016). Prospect-wide averaged data from the Delta mineral belt (excluding HD South) and the PP-LZ trend (fig. 20B; S. Dashevsky, written commun., 2016) indicate much higher concentrations of As (361 ppm to 1.42 percent) and $\mathrm{Sb}$ (90 to $964 \mathrm{ppm}$ ).

\section{Mineral compositions}

Rainer Newberry analyzed the compositions of key ore and alteration minerals by electron microprobe energy-dispersive X-ray spectrometry (EDS) at the University of Alaska Fairbanks.

Sphalerite from the Eagle trend prospects has compositions ranging from 11.2 to 14.6 molecular
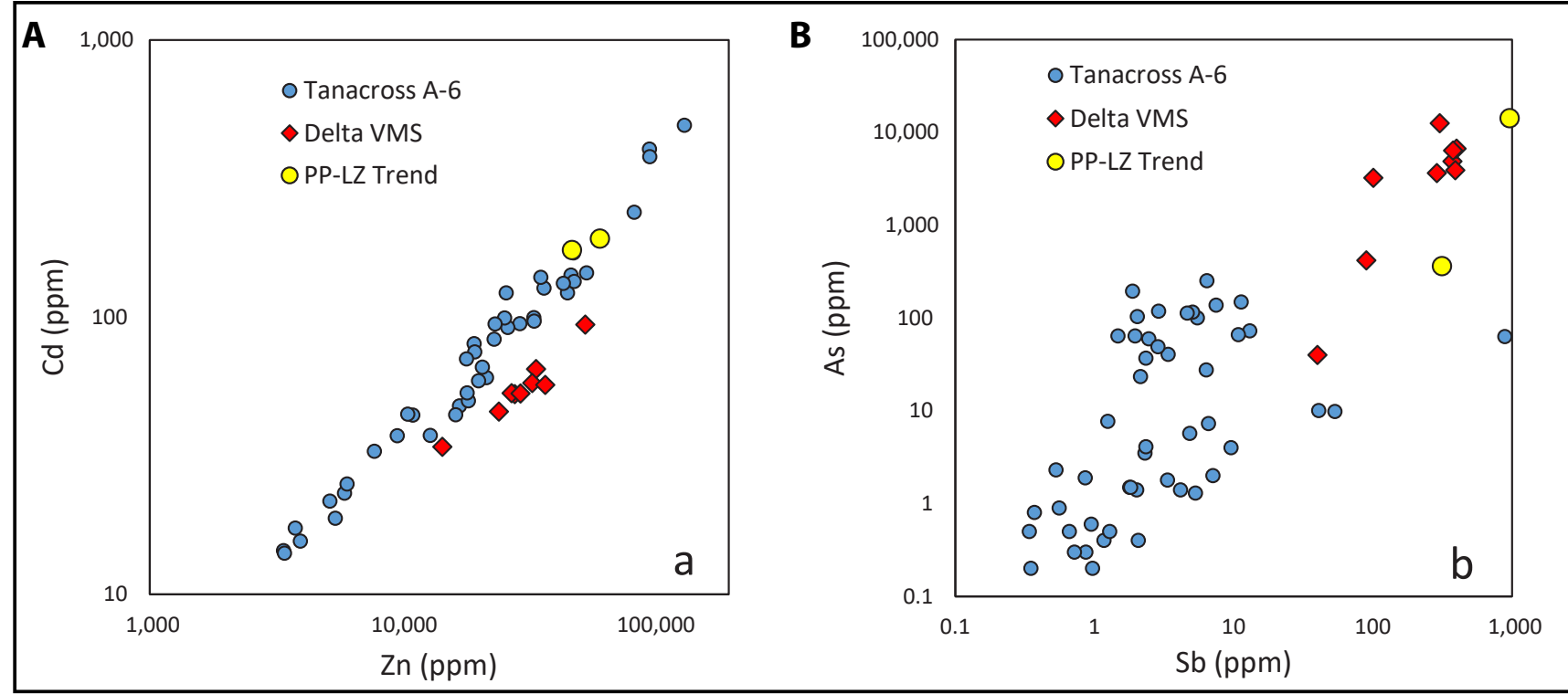

Figure 20. Bivariate scatter plot for trace elements at base-metal occurrences in the Tok River area. A. Cd vs. Zn; B. As vs. Sb. Delta district VMS and PP-LZ trend data are averages by prospect calculated from industry drilling and sampling (S. Dashevsky, written commun., 2016); individual samples are shown for prospects southeast of Dry Tok Creek (Wypych and others, 2016). 
Table 3. Composition (weight percent) and FeS content (molecular percent) of sphalerite from base-metal prospects in the Tanacross A-6 Quadrangle. Samples shown in bold are from sphalerite in physical contact with pyrite and pyrrhotite. Data collected using energy-dispersive spectrometry (EDS) on the microprobe at the University of Alaska Fairbanks, R.J. Newberry, analyst.

\begin{tabular}{|c|c|c|c|c|c|c|c|}
\hline Prospect & Sample & $\mathrm{S}$ & $\mathrm{Zn}$ & $\mathrm{Fe}$ & $\mathrm{Cd}$ & $\mathrm{Mn}$ & $\mathrm{FeS}$ \\
\hline \multicolumn{8}{|c|}{ Eagle Trend } \\
\hline Conehead & 16RN136B & 33.7 & 58.5 & 7.3 & 0.31 & 0.18 & $12.1 \pm 0.1$ \\
\hline West of Conehead & 16RN142C & 33.5 & 59.4 & 6.7 & 0.23 & 0.21 & $11.6 \pm 0.6$ \\
\hline $\mathrm{Nic}$ & 16RN210A & 33.8 & 59.3 & 6.4 & 0.29 & 0.21 & $11.3 \pm 1.3$ \\
\hline $\mathrm{Nic}$ & 16RN211 & 33.8 & 59.3 & 6.6 & 0.20 & 0.05 & $11.5 \pm 0.9$ \\
\hline Eagle & 16RN213A & 33.5 & 59.8 & 6.4 & 0.22 & 0.03 & $11.2 \pm 0.6$ \\
\hline Eagle & 16RN213B & 33.4 & 59.8 & 6.5 & 0.25 & 0.05 & $11.2 \pm 0.5$ \\
\hline Eagle & 16RN214B & 33.6 & 59.2 & 6.8 & 0.23 & 0.02 & $11.8 \pm 0.1$ \\
\hline Parton & 16RN214C & 33.6 & 59.8 & 6.4 & 0.19 & 0.06 & $11.7 \pm 0.8$ \\
\hline Jacqueline & 16RN265A & 33.6 & 58.8 & 7.1 & 0.28 & 0.13 & $12.1 \pm 0.2$ \\
\hline Jacqueline & 16RN265D & 33.6 & 59.5 & 6.7 & 0.16 & 0.05 & $11.7 \pm 0.5$ \\
\hline Jacqueline & 16RN265E & 33.8 & 59.3 & 6.6 & 0.04 & 0.31 & $11.4 \pm 1.1$ \\
\hline \multicolumn{7}{|c|}{ Eagle Trend average: } & $11.5 \pm 0.7$ \\
\hline \multicolumn{8}{|c|}{ Eastern group } \\
\hline Wrinkle & 16RN151A & 33.6 & 59.1 & 6.9 & 0.16 & 0.17 & $11.7 \pm 0.5$ \\
\hline Wrinkle & 16RN152C & 33.9 & 58.0 & 7.7 & 0.23 & 0.06 & $13.3 \pm 0.2$ \\
\hline Wrinkle & 16RN152D & 33.3 & 59.3 & 7.2 & 0.19 & 0.03 & $11.9 \pm 0.5$ \\
\hline Wrinkle & 16RN156 & 33.6 & 58.6 & 7.5 & 0.22 & 0.17 & $13.0 \pm 1.0$ \\
\hline Wrinkle Extension & 16RN158B & 33.9 & 56.7 & 8.3 & 0.32 & 0.08 & $14.6 \pm 0.9$ \\
\hline Ozone & 16RN159D & 33.8 & 57.9 & 7.8 & 0.27 & 0.10 & $13.2 \pm 0.2$ \\
\hline \multicolumn{7}{|c|}{ Eastern group average: } & $12.8 \pm 1.0$ \\
\hline
\end{tabular}

percent FeS (table 3). There does not appear to be a systematic difference between sphalerite compositions in physical contact with pyrite and pyrrhotite and those that are not. Prospects of the Eagle trend have slightly lower-FeS sphalerite than the eastern cluster of prospects in the Tanacross A-6 Quadrangle (Wrinkle, etc.; figs. 2, 3).

Clinopyroxene is $\mathrm{Fe}$ rich, with compositions approaching end-member hedenbergite: $\mathrm{Ca}_{0.98-1.05}\left(\mathrm{Fe}_{0.64-0.84}, \mathrm{Mg}_{0.09-0.22}, \mathrm{Mn}_{0.07-0.12}\right) \mathrm{Si}_{2} \mathrm{O}_{6}$ (fig. $21 \mathrm{~B}$; table 4$)$. In one sample, $16 \mathrm{RN} 142 \mathrm{C}$, coarsegrained clinopyroxene shows a zonation from relatively Fe-poor cores to Fe-rich rims.
Garnets are relatively both $\mathrm{Ca}$ and $\mathrm{Mn}$ rich, with compositions between grossular and spessartine, plus a lesser almandine component: $\mathrm{Ca}_{0.81-}$ ${ }_{1.40}, \mathrm{Mn}_{0.60-1.45}, \mathrm{Fe}^{2+}{ }_{0.47-1.18}\left(\mathrm{Al}_{1.81-1.90}, \mathrm{Fe}^{3+}{ }_{0.10-0.31}\right)$ $\left(\mathrm{SiO}_{4}\right)_{3}$ (fig. 21A; table 5). No significant zonation of garnet was observed.

Amphiboles occurring with base-metal mineralization approach ferro-actinolite composition, with analyses in the range of $\mathrm{Ca}_{1.82-2.03}$,$\mathrm{Na}_{0.0-0.33}\left(\mathrm{Fe}_{3.44-3.89}, \mathrm{Mg}_{0.86-1.23}, \mathrm{Mn}_{0.15-0.37}\right)\left(\mathrm{Si}_{7.72-}\right.$ $\left.{ }_{7.99}, \mathrm{Al}_{0.06-0.45}\right) \mathrm{O}_{22}(\mathrm{OH})$; atomic $\mathrm{Fe} /(\mathrm{Fe}+\mathrm{Mg})$ ranges from 0.74 to 0.82 (table 6 ). 


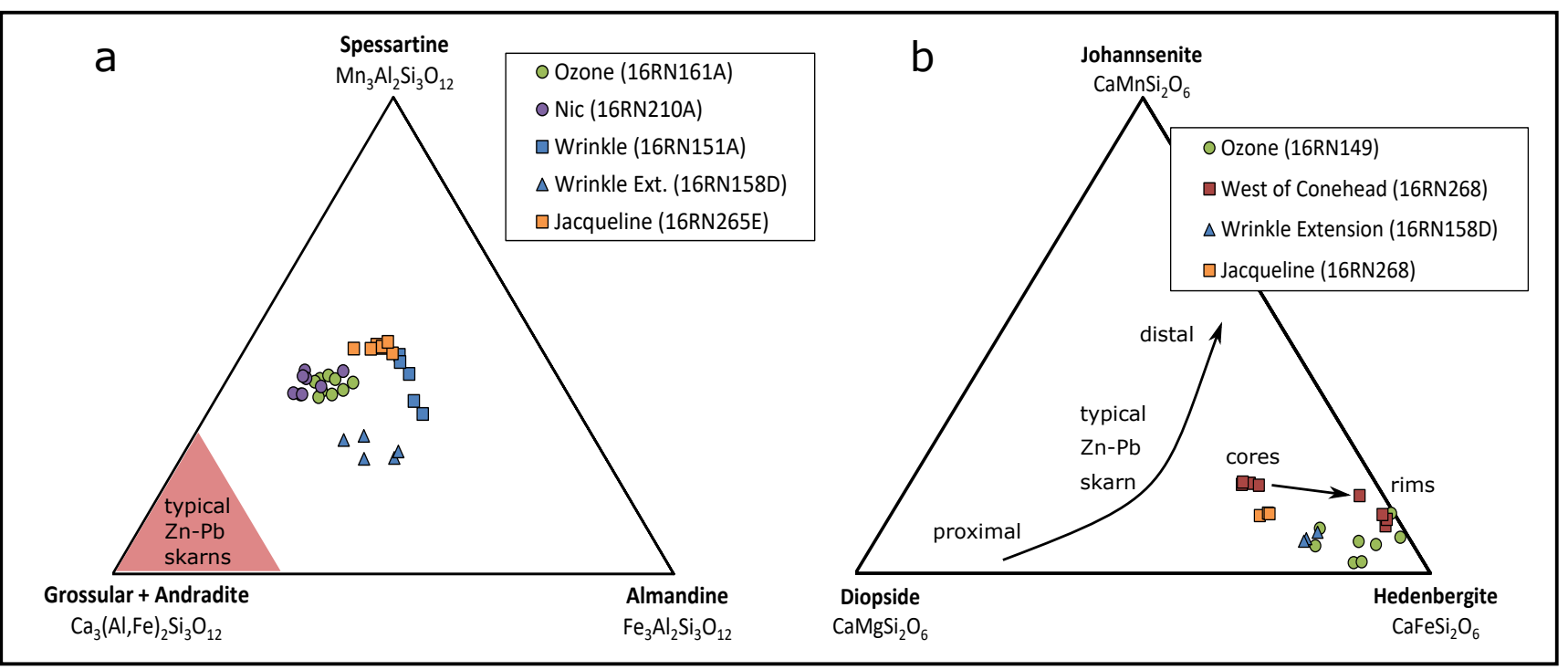

Figure 21. Garnet (A) and clinopyroxene (B) compositions from prospects in the Tanacross A-6 Quadrangle. Individual microprobe points from EDS are shown. The curved arrow shows typical clinopyroxene compositional change with distance from source intrusion in $\mathrm{Zn}-\mathrm{Pb}$ skarn systems.

Table 4. Pyroxene compositions, averaged by sample, for prospects in the Tanacross A-6 Quadrangle. Data determined by microprobe energy-dispersive spectrometry (EDS); R.J. Newberry, analyst. "-" indicates element not detected.

\begin{tabular}{|c|c|c|c|c|}
\hline Sample & 16RN142C & 16RN149 & 16RN158D & $16 \mathrm{RN} 268$ \\
\hline Prospect & West of Conehead & Upper Ozone & Wrinkle Extension & Jacqueline \\
\hline $\mathrm{n}$ & 9 & 8 & 4 & 3 \\
\hline \multicolumn{5}{|c|}{ Weight percent oxide: } \\
\hline $\mathrm{SiO}_{2}$ & 48.30 & 48.57 & 49.82 & 50.08 \\
\hline $\mathrm{Al}_{2} \mathrm{O}_{3}$ & 0.10 & 0.36 & 0.41 & 0.06 \\
\hline $\mathrm{FeO}$ & 21.44 & 24.60 & 21.90 & 18.97 \\
\hline $\mathrm{MnO}$ & 4.45 & 1.91 & 2.16 & 3.58 \\
\hline $\mathrm{MgO}$ & 2.02 & 1.47 & 2.85 & 3.66 \\
\hline $\mathrm{CaO}$ & 23.98 & 22.61 & 22.80 & 22.85 \\
\hline $\mathrm{Na}_{2} \mathrm{O}$ & - & 0.47 & 0.59 & 0.79 \\
\hline \multicolumn{5}{|c|}{ Number of cations (normalized to 6 oxygen): } \\
\hline $\mathrm{Si}$ & 1.97 & 1.98 & 2.00 & 2.00 \\
\hline Al & 0.00 & 0.02 & 0.01 & 0.00 \\
\hline $\mathrm{Fe}$ & 0.74 & 0.84 & 0.74 & 0.64 \\
\hline $\mathrm{Mn}$ & 0.15 & 0.07 & 0.07 & 0.12 \\
\hline $\mathrm{Mg}$ & 0.11 & 0.09 & 0.17 & 0.22 \\
\hline $\mathrm{Ca}$ & 1.05 & 0.99 & 0.98 & 0.98 \\
\hline $\mathrm{Na}$ & 0.00 & 0.04 & 0.01 & 0.06 \\
\hline \multicolumn{5}{|c|}{ End member components: } \\
\hline Diopside & 11 & 9 & 17 & 22 \\
\hline Johannsenite & 15 & 7 & 7 & 12 \\
\hline Hedenbergite & 73 & 84 & 75 & 65 \\
\hline
\end{tabular}


Table 5. Garnet compositions (microprobe EDS) from Tanacross A-6 Quadrangle prospects, averaged by sample. Fe ${ }^{2+}$ and $\mathrm{Fe}^{3+}$ are calculated on the assumption that Al, Ti, and Fe ${ }^{3+}$ total 2.0; R.J. Newberry, analyst. "-" indicates element not detected.

\begin{tabular}{|c|c|c|c|c|c|}
\hline Sample & 16RN151A & 16RN158D & 16RN161A & 16RN210A & 16RN265E \\
\hline Prospect & Wrinkle & Wrinkle Ext. & Ozone & Nic & Jacqueline \\
\hline $\mathrm{n}$ & 5 & 6 & 8 & 8 & 10 \\
\hline \multicolumn{6}{|c|}{ Weight percent oxide: } \\
\hline $\mathrm{SiO}_{2}$ & 37.00 & 37.45 & 36.86 & 36.92 & 36.94 \\
\hline $\mathrm{TiO}_{2}$ & - & 0.23 & 0.30 & 0.28 & 0.21 \\
\hline $\mathrm{Al}_{2} \mathrm{O}_{3}$ & 19.86 & 18.94 & 19.45 & 17.56 & 19.34 \\
\hline $\mathrm{FeO}$ & 15.87 & 20.23 & 10.90 & 11.39 & 12.65 \\
\hline $\mathrm{MnO}$ & 17.66 & 8.75 & 17.71 & 18.04 & 20.95 \\
\hline $\mathrm{MgO}$ & 0.22 & - & - & - & - \\
\hline $\mathrm{CaO}$ & 9.31 & 14.60 & 14.87 & 16.01 & 10.04 \\
\hline \multicolumn{6}{|c|}{ Number of cations (normalized to 12 oxygen): } \\
\hline Si & 3.00 & 3.03 & 2.98 & 3.02 & 3.01 \\
\hline $\mathrm{Ti}$ & 0.00 & 0.00 & 0.01 & 0.00 & 0.01 \\
\hline $\mathrm{Al}$ & 1.90 & 1.81 & 1.85 & 1.69 & 1.86 \\
\hline Fe (total) & 1.08 & 1.37 & 0.74 & 0.78 & 0.86 \\
\hline $\mathrm{Fe}^{3+}$ & 0.10 & 0.19 & 0.13 & 0.31 & 0.14 \\
\hline $\mathrm{Fe}^{2+}$ & 0.98 & 1.18 & 0.60 & 0.47 & 0.72 \\
\hline $\mathrm{Mn}$ & 1.22 & 0.60 & 1.21 & 1.25 & 1.45 \\
\hline $\mathrm{Mg}$ & 0.03 & 0.00 & 0.00 & 0.00 & 0.00 \\
\hline $\mathrm{Ca}$ & 0.81 & 1.27 & 1.29 & 1.40 & 0.88 \\
\hline \multicolumn{6}{|c|}{ End member components: } \\
\hline Grossular & 26 & 38 & 39 & 38 & 27 \\
\hline Andradite & 1 & 4 & 3 & 7 & 2 \\
\hline Spessartine & 40 & 20 & 39 & 40 & 48 \\
\hline Almandine & 33 & 39 & 19 & 15 & 24 \\
\hline
\end{tabular}

The microprobe was used to identify calcite, ankerite, and siderite in polished sections (table 1). Sample 16RN213C from the Eagle prospect contains intergrown calcite and dolomite, which, if in equilibrium, may be used as a geothermometer following the method of Powell and others (1984). Table 7 shows the average compositions of these two phases analyzed from an intergrown cluster of calcite and dolomite. The molecular fraction $\mathrm{Mg}$ in calcite averages $0.023 \pm 0.002$ and the molecular fraction $\mathrm{Fe}$ in dolomite averages $0.169 \pm 0.009$, together indicating a temperature of approximately $420^{\circ} \mathrm{C}$ (fig. 22).

\section{$\mathrm{Pb}$ isotope data}

Regionally, Devonian to Mississippian VMS and stratabound systems in Alaska are clearly 
Table 6. Actinolite compositions (microprobe EDS) from Tanacross A-6 prospects, averaged by sample; R.J. Newberry, analyst. "- indicates element not detected.

\begin{tabular}{|c|c|c|c|c|}
\hline Sample & 16RN210A & 16RN268 & 16RN161A & 16RN149 \\
\hline \multicolumn{5}{|c|}{ Weight percent oxide: } \\
\hline $\mathrm{SiO}_{2}$ & 52.2 & 52.6 & 51.9 & 50.2 \\
\hline $\mathrm{Al}_{2} \mathrm{O}_{3}$ & 0.4 & 0.3 & 0.3 & 2.5 \\
\hline $\mathrm{FeO}$ & 27.1 & 27.1 & 28.1 & 30.3 \\
\hline $\mathrm{MnO}$ & 2.3 & 2.9 & 2.2 & 1.1 \\
\hline $\mathrm{MgO}$ & 5.4 & 5.2 & 5.0 & 3.7 \\
\hline $\mathrm{CaO}$ & 12.5 & 11.8 & 12.4 & 11.1 \\
\hline $\mathrm{Na}_{2} \mathrm{O}$ & 0.4 & 0.3 & - & 1.1 \\
\hline \multicolumn{5}{|c|}{ Number of cations (normalized to 23 oxygen): } \\
\hline $\mathrm{Si}$ & 7.94 & 7.99 & 7.93 & 7.72 \\
\hline Al & 0.06 & 0.06 & 0.06 & 0.45 \\
\hline $\mathrm{Fe}$ & 3.44 & 3.44 & 3.59 & 3.89 \\
\hline $\mathrm{Mn}$ & 0.30 & 0.37 & 0.29 & 0.15 \\
\hline $\mathrm{Mg}$ & 1.23 & 1.17 & 1.15 & 0.86 \\
\hline $\mathrm{Ca}$ & 2.03 & 1.92 & 2.03 & 1.82 \\
\hline $\mathrm{Na}$ & 0.05 & 0.08 & 0.00 & 0.33 \\
\hline $\mathrm{Fe} /(\mathrm{Fe}+\mathrm{Mg})$ & 74 & 75 & 76 & 82 \\
\hline
\end{tabular}

distinguishable from Cretaceous intrusion-related mineral systems by $\mathrm{Pb}$ isotopic ratios (fig. 23). To help establish the appropriate deposit model for base-metal sulfide mineralization in the Tanacross A-6 Quadrangle, we submitted a representative group of sample pulps to ALS Minerals for $\mathrm{Pb}$ isotopic ratio analysis by ICP-MS (table 8; method code PbIS-RAT61). Measurement of $\mathrm{Pb}$ isotopic ratios is conventionally analyzed with thermal ionization mass spectrometry (TIMS) on mineral separates (e.g., galena); however, the ICP-MS method employs the same whole-rock pulp as the multi-element assay and is far less expensive. Petrographic work shows that $\mathrm{Pb}$ in our mineralized samples occurs as galena. Analytical uncertainties are far higher for the ICP-MS method; however, they are still small enough for our purposes.

\section{Discussion}

\section{Timing of mineralization}

Stratabound base-metal prospects of the Tanacross A-6 Quadrangle predate Permian through Early Cretaceous regional metamorphism. This conclusion is drawn from the presence of metamorphic mineral assemblages, local involvement of ore and gangue minerals in metamorphic fabrics, and sphalerite compositions, and is supported by $\mathrm{Pb}$ isotopic ratios. $\mathrm{Pb}$ isotopic ratios for many of the Tanacross A-6 Quadrangle samples are similar to those of Interior Alaska Devonian to Mississippian VMS and stratabound mineralization (fig. 23). Tanacross A-6 samples have a larger range of values of ${ }^{207} \mathrm{~Pb} /{ }^{204} \mathrm{~Pb}$; however, these samples plot along the same trend as the Paleozoic samples. Notably, the skarn-like, clinopyroxene-rich sample 16RN142C (west of 
Table 7. Average microprobe (EDS) analyses of adjacent and intergrown calcite and ferroan dolomite grains in sample 16RN213C (Eagle prospect). X refers to the mole fraction of the subscripted element. Errors are one standard deviation. R.J. Newberry, analyst.

\begin{tabular}{|c|c|c|}
\hline & Calcite & Dolomite \\
\hline $\mathrm{n}$ & 13 & 5 \\
\hline $\mathrm{FeO}$ & $3.7 \pm 1.0$ & $19.3 \pm 0.9$ \\
\hline $\mathrm{MnO}$ & $1.7 \pm 0.1$ & $3.4 \pm 0.3$ \\
\hline $\mathrm{CaO}$ & $75.2 \pm 2.4$ & $48.0 \pm 3.7$ \\
\hline $\mathrm{MgO}$ & $1.3 \pm 0.1$ & $17.2 \pm 1.6$ \\
\hline $\mathrm{CO}$ & $17.9 \pm 2.4$ & $12.1 \pm 5.4$ \\
\hline $\mathrm{X}_{\mathrm{Mg}}$ & $0.023 \pm 0.002$ & $0.266 \pm 0.015$ \\
\hline $\mathrm{X}_{\mathrm{Ca}}$ & $0.925 \pm 0.010$ & $0.535 \pm 0.014$ \\
\hline $\mathrm{X}_{\mathrm{Mn}}$ & $0.016 \pm 0.002$ & $0.030 \pm 0.003$ \\
\hline $\mathrm{X}_{\mathrm{Fe}}$ & $0.036 \pm 0.010$ & $0.169 \pm 0.009$ \\
\hline
\end{tabular}

Conehead) plots with the VMS mineralization. No samples have $\mathrm{Pb}$ isotopic values similar to the Mesozoic plutons and intrusion-related mineralization. Therefore, despite some similarities, the Tanacross A-6 Quadrangle base-metal prospects are not related to post-metamorphic Late Cretaceous skarn systems in the Tetlin area, such as the Peak skarn.

\section{Metamorphism of base-metal sulfide mineralization}

The FeS content of sphalerite, in the presence of pyrite and pyrrhotite, is controlled by the pressure and temperature at which these phases equilibrated. Sphalerite containing greater than about 16 molecular percent FeS component is restricted to low pressures, roughly comparable to the P-T stability field of andalusite (fig. 24; Toulmin and others, 1991). If the calc-silicate-rich Tanacross A-6 Quadrangle base-metal prospects were emplaced during the Late Cretaceous, their sphalerite compositions

Figure 22. Calcite-dolomite geothermometry of sample 16RN213C (Eagle prospect); method after Powell and others (1984). Error bars represent one standard deviation. would reflect a higher $\mathrm{FeS}$ component, indicative of hypabyssal conditions similar to those seen at the Peak skarn system (Illig, 2015) or the Hona stock.

The composition of Tanacross A-6 Quadrangle sphalerite (12.2-14.6 percent $\mathrm{FeS}$ ) is consistent with equilibration under conditions of upper greenschist facies regional metamorphism under a normal geothermal gradient (Toulmin and others, 1991). Further, calcite-dolomite geothermometry on a sample from the Eagle prospect (16RN213C) indicates a temperature of approximately $420^{\circ} \mathrm{C}$ (fig. 22; Powell and others, 1984). Combining this temperature estimate with the pyrite-pyrrhotite-buffered sphalerite composition measured at the Eagle prospect (11.2 percent FeS; table 3) yields a pressure of approximately 8 kilobars (fig. 24; Toulmin and others, 1991). These pressure and temperature estimates are consistent with upper greenschist facies metamorphic conditions, and they would not be compatible with the lower-pressure conditions assumed for the Late Cretaceous Peak skarn mineralization.

As demonstrated by natural skarn systems, hedenbergite and andradite garnet can be stable at greenschist facies temperatures in $\mathrm{Ca}-\mathrm{Fe}$-rich rocks under hydrous and $\mathrm{CO}_{2}$-poor conditions; phase diagrams also support this conclusion (Shoji, 1978;

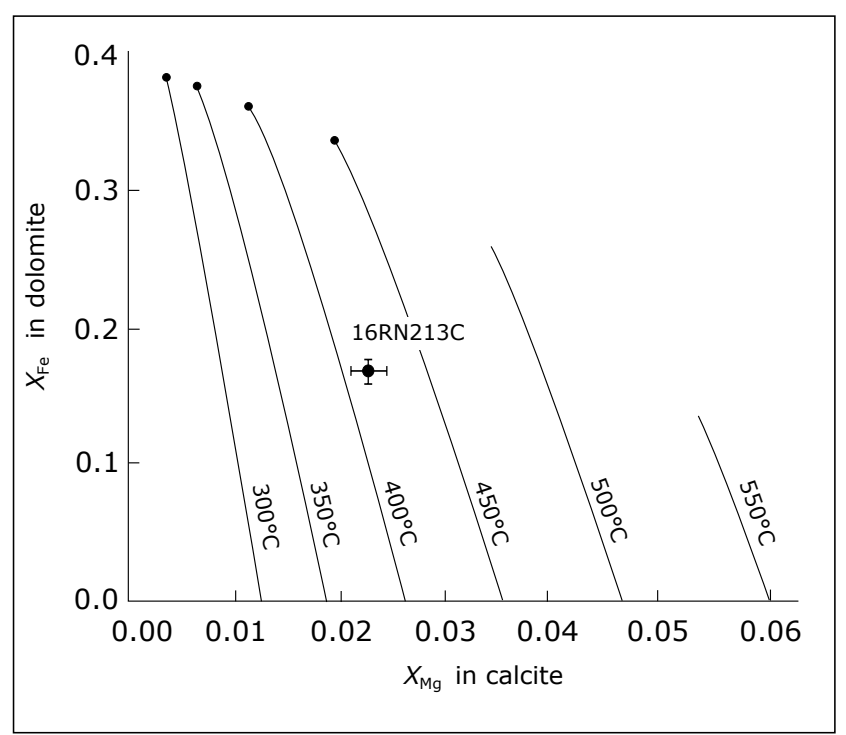




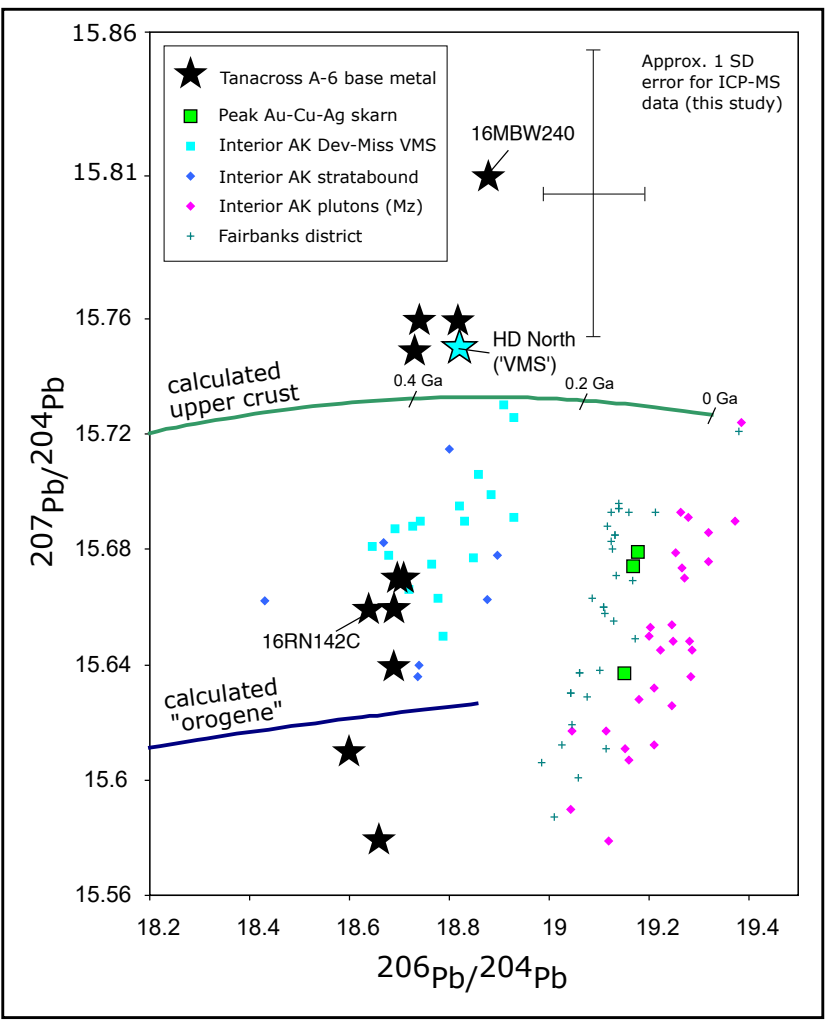

Figure 23. ICP-MS $\mathrm{Pb}$ isotopic data from base-metal prospects in the Tanacross A-6 Quadrangle plotted against data from the nearby Late Cretaceous Peak Au-Cu-Ag skarn and Devonian to Mississippian VMS occurrences, including the Delta mineral belt. Also shown are stratabound basemetal occurrences (Paleozoic), plutons (Mesozoic), and the mid-Cretaceous intrusion-related gold mineralization in the Fairbanks mining district. Comparative data are compiled from Illig (2015), Aleinikoff and others (1987), Gaccetta and Church (1989), Godwin and others (1988), and Newberry and others (1988).

Meinert and others, 2005). Manganese-rich rock compositions also decrease the temperature required for metamorphic garnet formation, making spessartine-rich garnet stable at greenschist facies conditions (Symmes and Ferry, 1992). Stilpnomelane is a common Fe-silicate mineral in low-grade metamorphosed iron formations (Klein, 1983) and is stable up to $460^{\circ} \mathrm{C}$ at 7 kilobars' pressure (Nitsch, 1971). Its occurrence is presumably related to high-Fe bulk compositions, as it is among the most Fe-rich hydrous silicate minerals (28-37 weight percent $\mathrm{FeO})$. On the basis of this information, we attribute the unusual silicate mineralogy of these prospects to the unusually high bulk Fe and $\mathrm{Mn}$ content of the rocks, together with the aforementioned greenschist facies metamorphic conditions.

\section{Similarity to the PP-LZ trend of prospects}

The Eagle trend prospects in the Tanacross A- 6 Quadrangle appears to be a direct continuation of similarly styled prospects that are part of the PP-LZ trend (Culp, 1982) northwest of Dry Tok Creek (fig. 4). Mineralogical differences may be explained in part by apparently higher metamorphic grades in the Tanacross A-6 Quadrangle.

As described by Culp (1982), the PP-LZ trend (figs. 2, 4) comprises two separate types of mineralization: stratabound sulfides associated with marble, and stratiform sulfides in graphitic metasedimentary rocks. Marble-hosted sulfides are medium to coarse grained, pyrrhotite rich, and base-metal poor. They occur in one to five thin marble horizons, but only a small proportion of the outcropping marble along the trend is mineralized. Mineralization occurs as massive sulfides, concordant layers or lenses, or anastomosing layers subparallel to foliation; hydrothermal dolomitization is commonly, but not exclusively, associated with mineralization. Mineralization associated with graphitic rocks is fine grained, base-metal rich, and characterized by strong lateral continuity and interlamination with graphitic metasedimentary rocks. Gangue minerals for all types include dolomite, quartz, and chlorite. Sulfide minerals include abundant pyrite, pyrrhotite, marcasite, sphalerite, galena, chalcopyrite, tennantite, and electrum. Pyrite locally displays possible colloform and/or framboidal textures defined by concentrically interlayered pyrite, marcasite, and base-metal sulfide. Marcasite described by Culp (1982) is apparently of primary origin and not bird's-eye marcasite formed by supergene weathering of pyrrhotite.

The stratabound base-metal prospects of the Tanacross A-6 Quadrangle are most similar to the 
Table 8. Whole-rock ICP-MS Pb isotopic ratios for Pb-rich samples from base-metal prospects in the Tanacross A- 6 Quadrangle. Approximate $1-\sigma$ errors (based on information provided by ALS Minerals) are \pm 0.05 for ${ }^{207} \mathrm{~Pb} /{ }^{204} \mathrm{~Pb}$ and $\pm 0.1 \mathrm{for}{ }^{206} \mathrm{~Pb} /{ }^{204} \mathrm{~Pb}$.

\begin{tabular}{|c|c|c|c|c|c|c|c|c|}
\hline Sample & Prospect & $\mathrm{Pb}(\mathbf{p p m})$ & $\begin{array}{c}{ }^{206} \mathrm{~Pb} / \\
{ }^{204} \mathrm{~Pb}\end{array}$ & $\begin{array}{c}{ }^{207} \mathrm{~Pb} / \\
{ }^{204} \mathrm{~Pb}\end{array}$ & $\begin{array}{c}{ }^{208} \mathrm{~Pb} / \\
{ }^{204} \mathrm{~Pb}\end{array}$ & $\begin{array}{c}{ }^{208} \mathrm{~Pb} / \\
{ }^{206} \mathrm{~Pb}\end{array}$ & $\begin{array}{c}{ }^{208} \mathrm{~Pb} / \\
{ }^{207} \mathrm{~Pb}\end{array}$ & $\begin{array}{c}{ }^{206} \mathrm{~Pb} / \\
{ }^{207} \mathrm{~Pb}\end{array}$ \\
\hline 16RN266A & Jacqueline & 806 & 18.69 & 15.66 & 38.71 & 2.071 & 2.473 & 1.197 \\
\hline 16RN267 & Jacqueline & 20,400 & 18.69 & 15.64 & 38.71 & 2.071 & 2.475 & 1.198 \\
\hline 16RN214B & Parton & 88,000 & 18.7 & 15.67 & 38.63 & 2.066 & 2.466 & 1.196 \\
\hline 16RN213A & Eagle & 12,750 & 18.66 & 15.58 & 38.35 & 2.055 & 2.461 & 1.196 \\
\hline 16RN142C & $\begin{array}{c}\text { West of } \\
\text { Conehead }\end{array}$ & 2840 & 18.64 & 15.66 & 38.59 & 2.071 & 2.465 & 1.192 \\
\hline 16ET278 & Conehead & 859 & 18.71 & 15.67 & 38.78 & 2.073 & 2.475 & 1.197 \\
\hline 16RN211 & Nic & 46,200 & 18.82 & 15.76 & 39.09 & 2.078 & 2.481 & 1.199 \\
\hline 16RN151A & Wrinkle & 42,300 & 18.6 & 15.61 & 38.5 & 2.069 & 2.466 & 1.192 \\
\hline 16RN155A & Wrinkle & 2,680 & 18.73 & 15.75 & 39.12 & 2.089 & 2.484 & 1.194 \\
\hline 16RN156 & Wrinkle & 14,650 & 18.74 & 15.76 & 38.89 & 2.076 & 2.469 & 1.192 \\
\hline 16MBW240 & $\begin{array}{c}\text { Skarn-like } \\
\text { occurrence }\end{array}$ & 658 & 18.88 & 15.81 & 39.26 & 2.079 & 2.483 & 1.197 \\
\hline 16ET001 & HD North (VMS) & 6,850 & 18.82 & 15.75 & 38.93 & 2.069 & 2.472 & 1.197 \\
\hline
\end{tabular}

marble-hosted subset of the PP-LZ trend; the principal similarity is the style of mineralization within multiple marble horizons. Differences include a lack of stilpnomelane, garnet, clinopyroxene, and actinolite gangue minerals along the PP-LZ trend, and lack of significant dolomitization of marble in the Tanacross A-6 Quadrangle. Geochemically, the two groups of prospects show a similarly scattered range of $\mathrm{Zn}: \mathrm{Cu}: \mathrm{Pb}$ ratios (fig. 19) and have very similar $\mathrm{Zn}: \mathrm{Cd}$ ratios, which set them apart from the VMS deposits of the Delta mineral belt to the north (fig. 20A). Although moderately graphitic layers are a part of the map unit (MDcs) that hosts the Eagle trend prospects, laminated-style mineralization hosted by graphitic rocks has not been noted in the Tanacross A-6 Quadrangle, with the possible exception of one outcrop at Nic described by Degenhart (1978) but not relocated by DGGS.

Some of the mineralogical differences between the PP-LZ trend and the Tanacross A-6 Quadrangle prospects may be explained by differences in

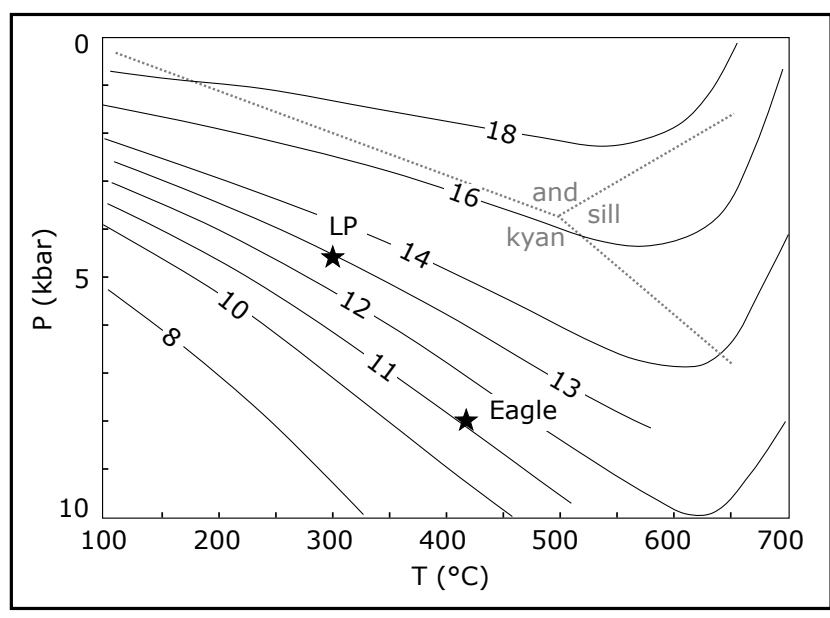

Figure 24. FeS content (in percent) of sphalerite in equilibrium with the assemblage pyrite-pyrrhotite (numbered curves) as a function of temperature and pressure (method of Toulmin and others, 1991). Stability fields for andalusite (and), sillimanite (sill), and kyanite (kyan) are shown in gray.

metamorphic grade. As described by Culp (1982), the PP-LZ prospects are metamorphosed to lower greenschist facies temperatures, as indicated by the assemblage quartz-sericite-chlorite-carbonate and the 
local occurrence of prehnite, pumpellyite, margarite, and epidote. Stilpnomelane is locally present, but not in the abundance seen at the Tanacross A- 6 prospects. Albite is conspicuously absent, which Culp (1982) attributes to a high-Ca bulk composition.

Similarly, textural evidence suggests that the PP-LZ prospects experienced low-grade metamorphism. Our petrographic work on the Tanacross A-6 prospects indicates that pyrite typically has a cubic (porphyroblastic) habit, and we did not observe the colloform or possible framboidal structures described by Culp (1982) at the PP-LZ trend. The marcasite we identified at the Tanacross prospects was of the bird's eye variety resulting from supergene weathering of pyrrhotite, whereas Culp (1982) describes marcasite as a primary ore mineral.

\section{Relationship to the Delta mineral belt VMS systems}

Dashevsky and others (2003) interpret the prospects of the PP-LZ trend to be hosted by a thrust-faulted repetition of the Lagoon unit. The main (northern) occurrence of this unit hosts most of the economically significant deposits of the Delta mineral belt (DW-LP, PP2, TRIO; fig. 4). The correlation of the PP-LZ trend to the Lagoon unit is supported by the general lithologic similarities, including the presence of graphitic sediments, and by a small body of metavolcanic rock correlated to the Tiger unit mapped at the top of the repeated Lagoon section. This rock yielded a U-Pb SHRIMP zircon age of $372 \pm 5.8 \mathrm{Ma}$, similar to the age of the metavolcanic rocks overlying the main (northern) Lagoon unit (Drum unit; zircon ages of 372 to $358.6 \pm 6.2 \mathrm{Ma}$; Dashevsky and others, 2003).

The northern Lagoon unit rocks are metamorphosed to similar lower greenschist facies assemblages. Lange and others (1993) describe a gangue assemblage of chlorite, quartz, ankerite, sericite, and biotite; it is possible that stilpnomelane was misidentified as biotite or that biotite results from the contact metamorphic effects of mafic sills intruded in the
Triassic. Rao (1988) determined that arsenopyrite in the pyrite-rich LP zone contains 30.2 atomic percent As. Using the geothermometer of Sharp and others (1985), the arsenopyrite composition (in presumed equilibrium with pyrite) indicates an approximate temperature of $310^{\circ} \mathrm{C}$, consistent with lower greenschist facies mineral assemblages. In contrast, the combination of calcite-dolomite geothermometry and sphalerite compositions indicate upper greenschist facies conditions for the Eagle trend.

The greater depth of metamorphism of the Eagle trend in comparison to the PP-LZ trend may be explained by dip-slip offset (southeast side up?) on the northeast-trending fault inferred to run through the Dry Tok valley (fig. 2; Sicard and others, 2017). However, this interpretation is complicated by map patterns that indicate either left-lateral or northwest-up apparent offset of the Macomb-Jarvis contact across the Dry Tok fault in the area northeast of the Tok River. The limited mineral assemblage data we reviewed do not show significant differences in the depth of metamorphism between the PP-LZ trend and other (northern) prospects of the Delta mineral belt. This seems to indicate that thrust-repetition of the Lagoon unit occurred prior to peak metamorphism.

\section{Deposit model}

The Tanacross A-6 Quadrangle prospects comprise disseminated to massive stratabound base-metal sulfide mineralization hosted by thin layers of marble within a siliceous metasedimentary sequence. The metasedimentary section hosting the prospects is unlike a normal VMS environment in that it contains only minor metavolcanic rocks. Likewise, the area lacks syn-mineral intrusions that typically occur adjacent to skarn mineral deposits; in fact, no intrusions of any age were mapped in the vicinity of these prospects (Sicard and others, 2017). Consequently, the models suggested by geographic and temporal proximity (VMS) or mineralogy (skarn) are not a perfect fit. 
The Fe-, Mn-, and Ca-rich gangue silicates (clinopyroxene, Ca-Mn garnet, ilvaite, Fe-actinolite, stilpnomelane, etc.) are "skarn" in the most general and non-genetic sense of the word; however, the Tanacross A-6 Quadrangle prospects do not fit the skarn mineral deposit model in the economic geology sense (Meinert and others, 2005). The absence of a known causative intrusion is unusual, but not unheard of, for skarn systems; in particular, $\mathrm{Zn}-\mathrm{Pb}$ skarns may occur in distal settings where the intrusion is undiscovered. That said, the best-exposed prospects (e.g., Wrinkle; fig. 17) have a complex anastomosing pattern of sulfide within impure marble. There is no "skarn front." While hydrothermal fluids introduced large amounts of $\mathrm{Fe}, \mathrm{Mn}$, and base metals, there is no strong evidence that they introduced $\mathrm{Si}$, which typically is more mobile than the base metals and can form a wollastonite zone distal to pyroxene skarn (Meinert and others, 2005). More likely, the calc-silicate minerals are the result of a combination of quartz- and mica-bearing impure marble, Paleozoic Fe-Mn metasomatism, and Permian through Early Cretaceous upper greenschist facies regional metamorphic conditions.

Furthermore, the compositions of garnet and pyroxene in the study area are atypical of $\mathrm{Zn}-\mathrm{Pb}$ skarns. Garnet is more enriched in $\mathrm{Mn}$ and $\mathrm{Fe}^{2+}$ than is typically found in $\mathrm{Zn}-\mathrm{Pb}$ skarns, and clinopyroxene shows evolution toward high Fe content, rather than from $\mathrm{Mg}$ - towards $\mathrm{Mn}$-rich compositions, as is typically observed in $\mathrm{Zn}$-Pb skarn systems (fig. 21).

Culp (1982) concludes that the PP-LZ trend prospects are most likely sedimentary-exhalative (SEDEX)-type systems. In his interpretation, the PP-LZ mineralized horizon formed following the deposition of a thick sequence of rhyolitic volcaniclastic rocks and a transition from a shallow depositional environment to one of deeper water and anoxic, rift-related basins. Laminated sulfides hosted in graphitic rocks were deposited syngenetically by hydrothermal brines discharged into the water column, while carbonate-hosted sulfides formed by partial replacement of unconsolidated sediments near the seawater interface. We infer that the Tanacross A-6 Quadrangle sulfide prospects formed similarly, by replacement of unconsolidated carbonate sediments below, but possibly near, the seawater interface.

$\mathrm{Zn}: \mathrm{Cd}$ ratios for the $\mathrm{PP}-\mathrm{LZ}$ trend and the Tanacross A-6 Quadrangle prospects, both close to 300 (Wypych and others, 2016; S. Dashevsky, written commun., 2018), fall within the range documented by Wen and others (2016) for SEDEX systems. They are higher than the $\mathrm{Zn}: \mathrm{Cd}$ ratios (around 200) for deposits closely associated with igneous rocks, including porphyry, skarn, and VMS systems. The Zn:Cd ratios set the Tanacross A-6 Quadrangle prospects apart from Mississippi Valley-type systems, which have $\mathrm{Zn}$ :Cd ratios lower than 200. Interestingly, the $\mathrm{Zn}$ :Cd ratio for Delta mineral belt mineralization is higher, averaging 544 (S. Dashevsky, written commun., 2018), and also similar to SEDEX systems as described by Wen and others (2016).

$\mathrm{Pb}$-isotopic data are also consistent with a SEDEX genetic model for the Tanacross A-6 prospects. Samples plotting above the "calculated Upper Crust" curve in figure 23, if not attributable to analytical error, indicate high ${ }^{238} \mathrm{U} /{ }^{204} \mathrm{~Pb}(\mu)$ in the $\mathrm{Pb}$ source reservoir; this is consistent with $\mathrm{Pb}$ sourced from radiogenic upper crust, or from sediments derived from such crust. Unusually high $\mu$ values are seen in the data for SEDEX deposits globally because these deposits are formed from metals sourced from basin-fill sediments in rifted continental or passive margin settings (Leach and others, 2005). VMS deposits typically have lower values of $\mu$ similar to that of their associated igneous rocks (Franklin and others, 2005).

Based on the above information, the Tanacross A-6 prospects are most likely to be a carbonate-hosted variant of the SEDEX model. Key differences, the relatively large grain size and unusual silicate mineralogy, may be easily explained by metamorphism to upper greenschist facies. 


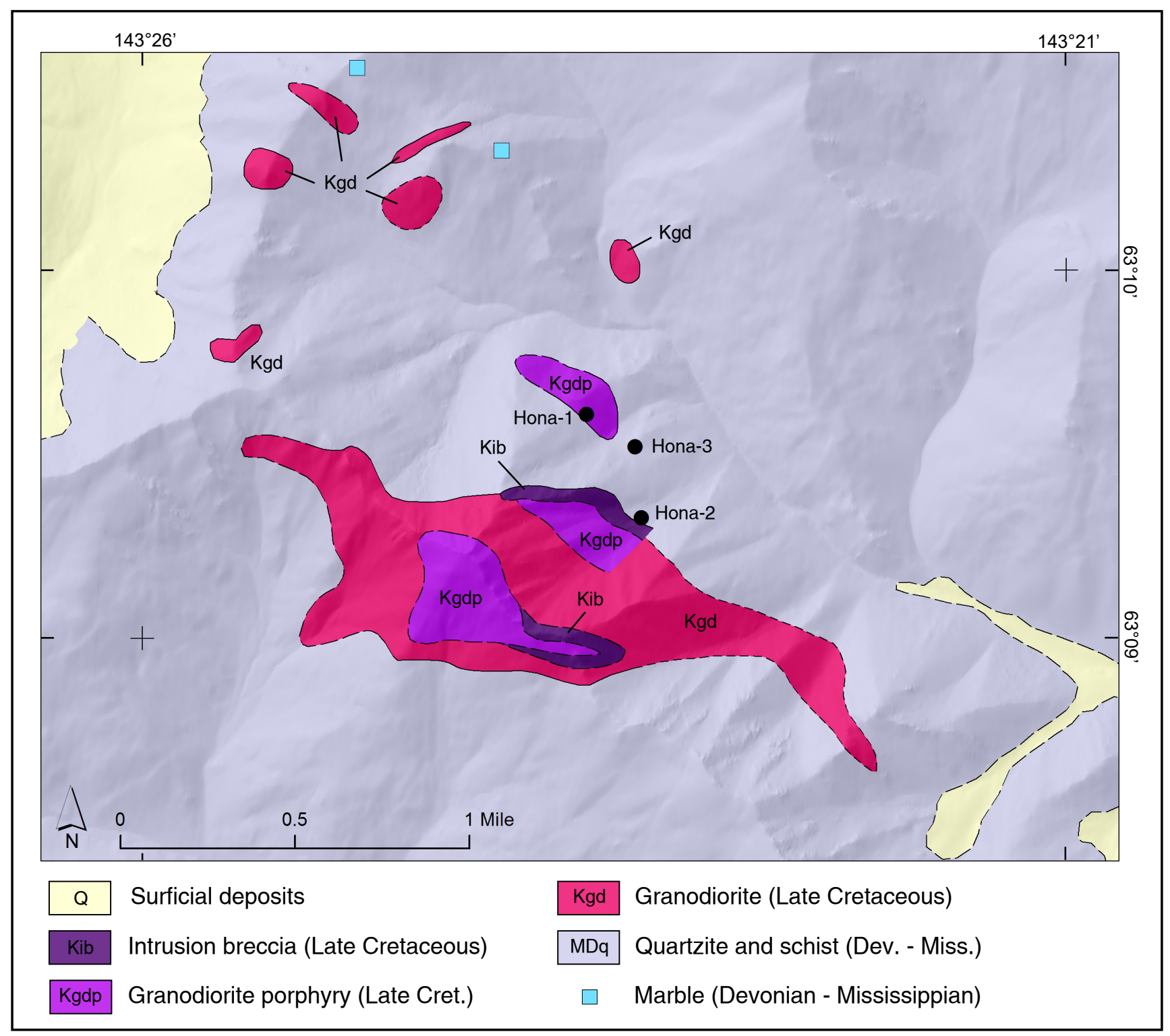

Figure 25. Geologic map of the Hona prospect area, modified from Sicard and others (2017) to show the different phases of the Hona stock. See figure 2 for the location of the Hona prospect. Industry drill holes shown as black dots.

\section{GOLD MINERALIZATION}

\section{Hona prospect}

The Hona prospect comprises $\mathrm{Au}, \mathrm{Cu}, \mathrm{Ag}$, and local Mo mineralization developed adjacent to, and within, a multiphase hypabyssal intrusive stock of Late Cretaceous (ca. $75 \mathrm{Ma}$; Benowitz and others, 2017) age (fig. 25). The prospect is of similar age and chemistry to the skarn mineralization at the nearby Tetlin project (Peak skarn; Illig, 2015), but, unlike at Tetlin, mineralization is directly associated with the intrusive body.

\section{Exploration history}

Hona (also known as Noah) was known as a copper prospect prior to 1976 when it was included in a regional compilation by Singer and others (1976). A review of publicly available Alaska Department of Natural Resources records shows that Pacific Coast Mines Inc. (a subsidiary of U.S. Borax) staked the prospect in 1978 and still held it in 1984. Resource Associates of Alaska (RAA) staked the prospect in 1986. No details of the pre-1990's exploration were available for our review. 

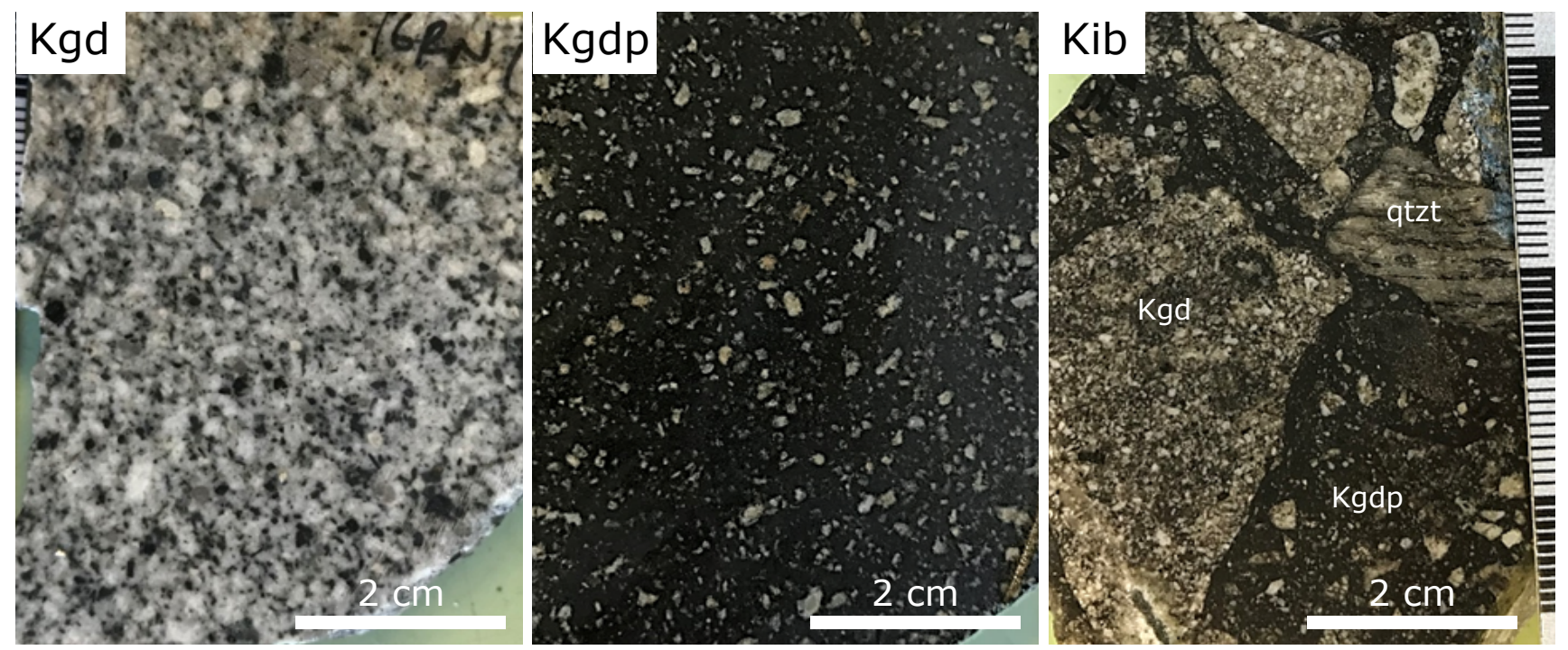

Figure 26. Main intrusive phases of the Hona stock. Kgd - granodiorite; Kgdp - granodiorite porphyry; Kib - intrusion breccia. Intrusion breccia at right contains clasts of quartzite country rock (qtzt) as well as granodiorite; the matrix bears a strong resemblance to the granodiorite porphyry.

The prospect was again staked by Pacific Northwest Resources in 1997 and then optioned to Kennecott Exploration in 1998. Kennecott Exploration conducted exploration and drilling on the property that year. This included geologic mapping, geochemical sampling, a helicopter-borne magnetic and electromagnetic survey (DIGHEM), and three diamond drill holes (Hona-1, 260 m; Hona-2, 395 m; and Hona-3, 229 m; fig. 25). Representative "skeletons" of the diamond drill holes are held by DGGS at the Geologic Materials Center in Anchorage.

The prospect was again staked in 2016 by Peak Gold LLC as part of a larger claim block covering the area between the Tok River and the Alaska Highway. Peak Gold conducted exploration of the property in conjunction with their advanced-stage Tetlin gold project.

\section{Hona intrusive stock}

The Hona stock (fig. 25) consists of fine- to medium-grained phaneritic granodiorite intruded by granodiorite porphyry that may also form the matrix of locally developed magmatic breccias. The phaneritic granodiorite phase (Kgd; fig. 26) is hypidiomorphic, seriate to porphyritic, and contains -10 percent 2-mm-diameter orthoclase phenocrysts, -30 percent 0.5 - to $1-\mathrm{mm}$-long plagioclase, -30 percent interstitial potassium feldspar, -15 percent interstitial quartz, -15 percent biotite, hornblende, and trace accessory zircon. Interstitial biotite is very fine grained, often altered to chlorite, with occasional larger $(-0.2-\mathrm{mm}$-diameter), fresh blades. Fine-grained biotite is often accompanied by small opaque minerals. Large, fractured K-feldspar phenocrysts remain euhedral with visible zonation and little to no alteration. Smaller K-feldspar crystals have sericite- and biotite-altered cores. The magnetic susceptibility of unaltered Hona granodiorite ranges from 0.2 to $0.9 \mathrm{x}$ $10^{-3}$ Système International (SI) and averaging $0.5 \mathrm{x}$ $10^{-3} \mathrm{SI}$. Ilmenite series granitic rocks typically have magnetic susceptibility of $3.0 \times 10^{-3}$ SI or lower (Ishihara and others, 2000).

Benowitz and others (2017) dated weakly altered Hona granodiorite in two locations using the ${ }^{40} \mathrm{Ar} /{ }^{39} \mathrm{Ar}$ method. Primary biotite yielded a plateau age of $73.1 \pm 0.9 \mathrm{Ma}$, and hornblende from a nearby sample yielded a plateau age of $75.8 \pm 0.6 \mathrm{Ma}$. 

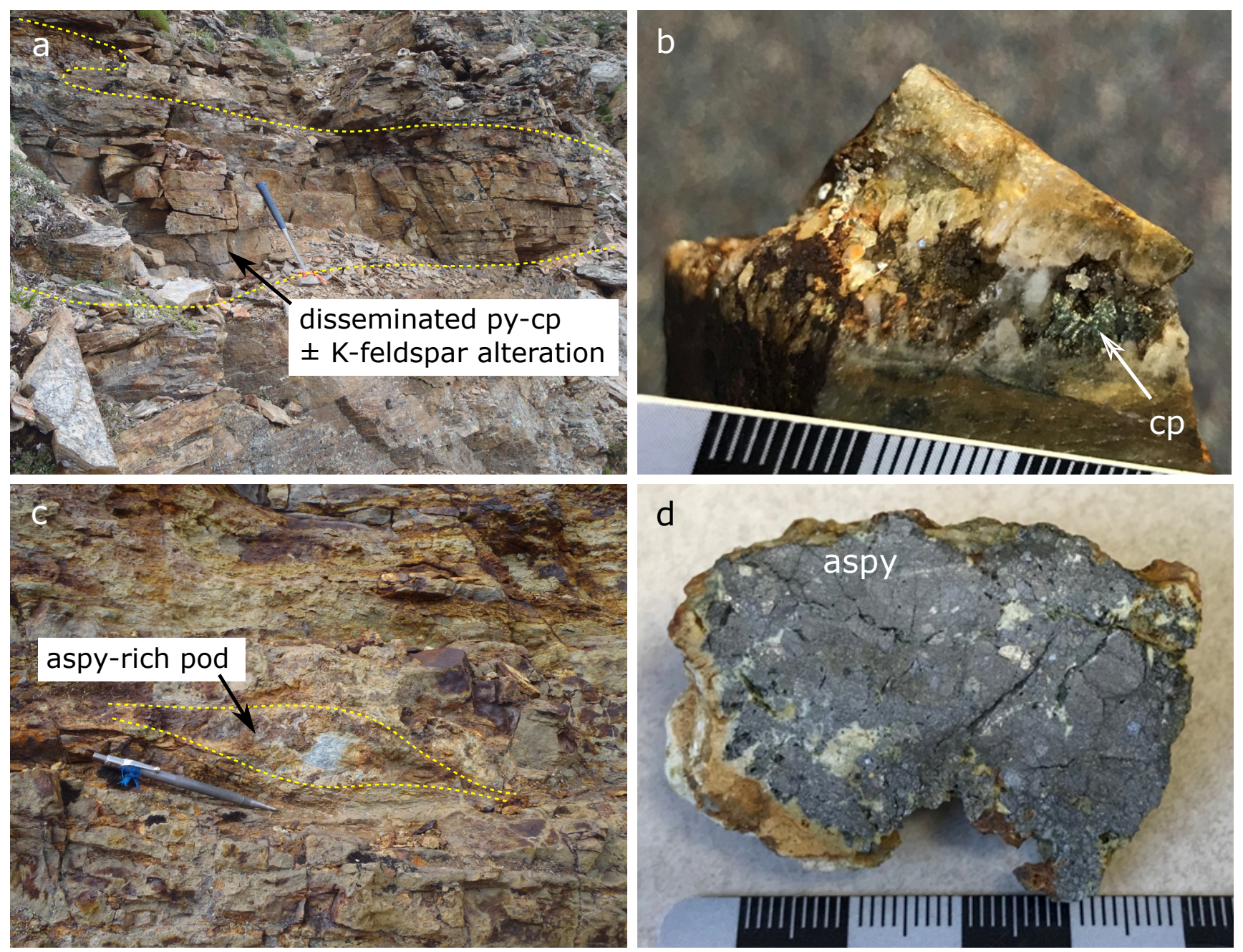

Figure 27. Mineralization in the country rock adjacent to the Hona stock. A. Gossanous bands of disseminated pyrite and chalcopyrite follow layering of the quartzite to quartz schist; (B) vuggy quartz-chalcopyrite veinlet (16ET312; Wypych and others, 2016; 6.25 ppm Au, 19.4 ppm Ag, 2,300 ppm Cu); (C) arsenopyrite pod in strongly iron-stained quartzite; (D) close-up of arsenopyrite-rich sample (15ET026; Wypych and others, 2015; 14.5 ppm Au, 19 percent As).

The granodiorite porphyry phase (Kgdp; fig. 26) contains phenocrysts of $\sim 10$ percent rounded quartz, -15 percent euhedral potassium feldspar, -20 percent euhedral to subhedral plagioclase, -5 percent subhedral biotite, and -5 percent euhedral to subhedral hornblende in a very fine grained matrix of feldspar, quartz, and mafic minerals $(-45$ percent of the rock). Rare hornblende is slightly chloritized; feldspar crystals are often sericitized. The magnetic susceptibility of this unit ranges from 0.1 to $2.85 \mathrm{x}$ $10^{-3} \mathrm{SI}$ and averages $0.58 \times 10^{-3} \mathrm{SI}$.
Well-developed magmatic-matrix breccias (Kib; fig. 26) occur locally at the edges of granodiorite porphyry intrusions. Dark-colored, very fine grained matrix comprises about 50 percent of the breccias; this matrix bears a strong resemblance to the granodiorite porphyry. Clasts are subangular, matrix supported, poorly sorted, and range from sub-millimeter to $20 \mathrm{~cm}$ in diameter; they include both schistose quartzite country rock and fragments of the phaneritic granodiorite. The magnetic susceptibility of this unit (including altered and mineralized rocks) is 0.1 to $1.43 \times 10^{-3} \mathrm{SI}$ and averages 0.55 


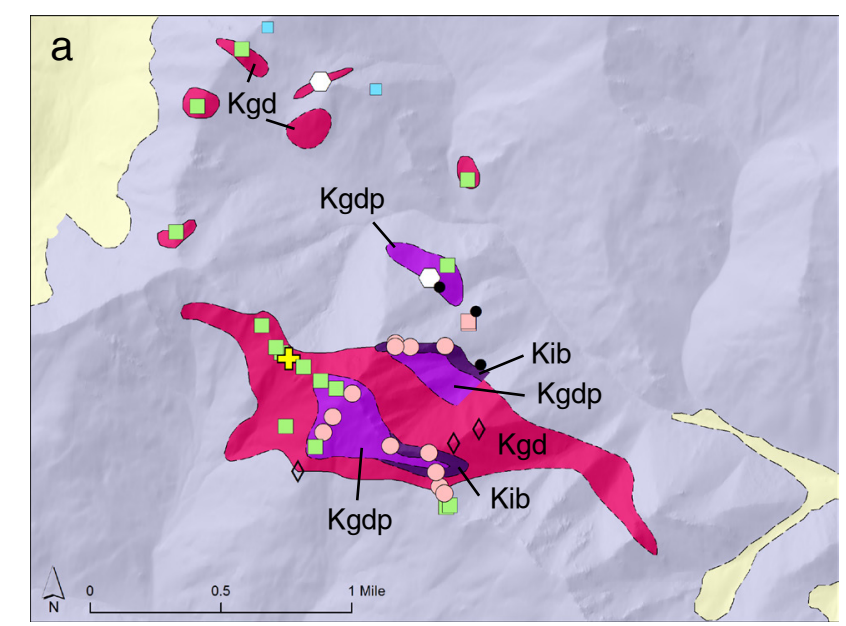

Alteration assemblage

$\bigcirc$ Secondary biotite

$\square$ Secondary K-feldspar replacement of schist

$\square$ Chlorite-sericite-carbonate after mafics

§ Advanced argillic

$\square$ Silicification

$\diamond$ Unaltered intrusive rock

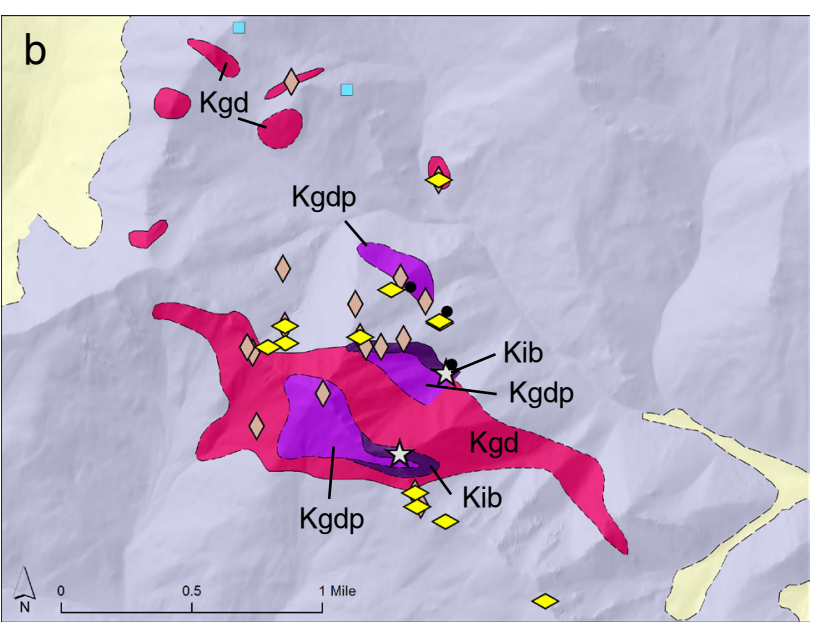

Sulfide mineralogy

$\diamond$ Pyrite

$\diamond$ Pyrrhotite

约 Molybdenite

Figure 28. Distribution of (A) alteration mineral assemblages and (B) sulfide minerals at the Hona prospect. See figure 25 for geologic legend.
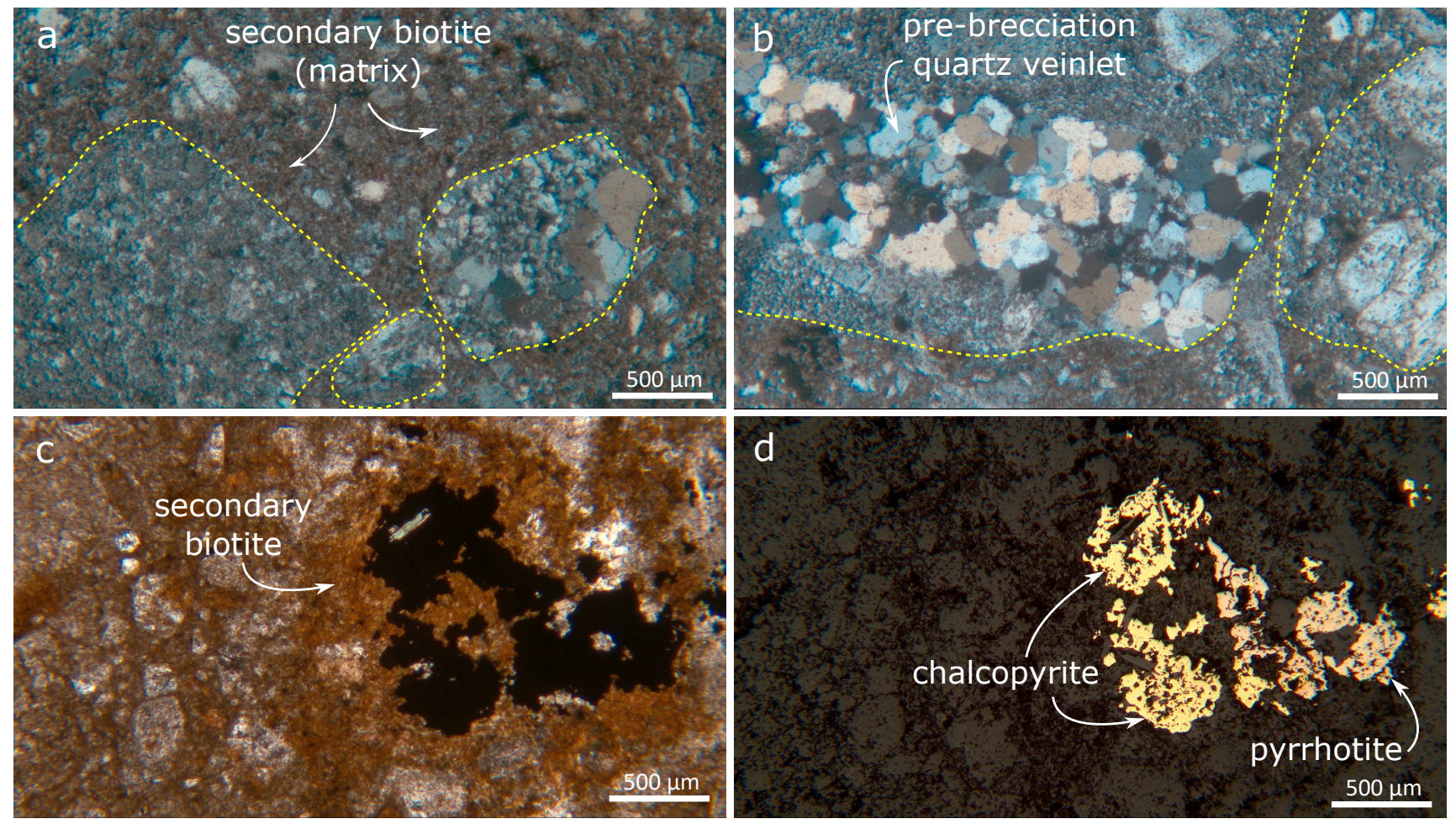

Figure 29. Photomicrographs of altered and mineralized intrusion breccia at Hona. (A) Moderate secondary biotite alteration of breccia matrix (XPL; sample 16RN178); (B) pre-brecciation quartz veinlet preserved in a clast (XPL; sample 16RN178); (C) strong secondary biotite alteration of breccia matrix (PPL) accompanying (D) chalcopyrite-pyrrhotite mineralization (reflected light; sample 16ET316). 


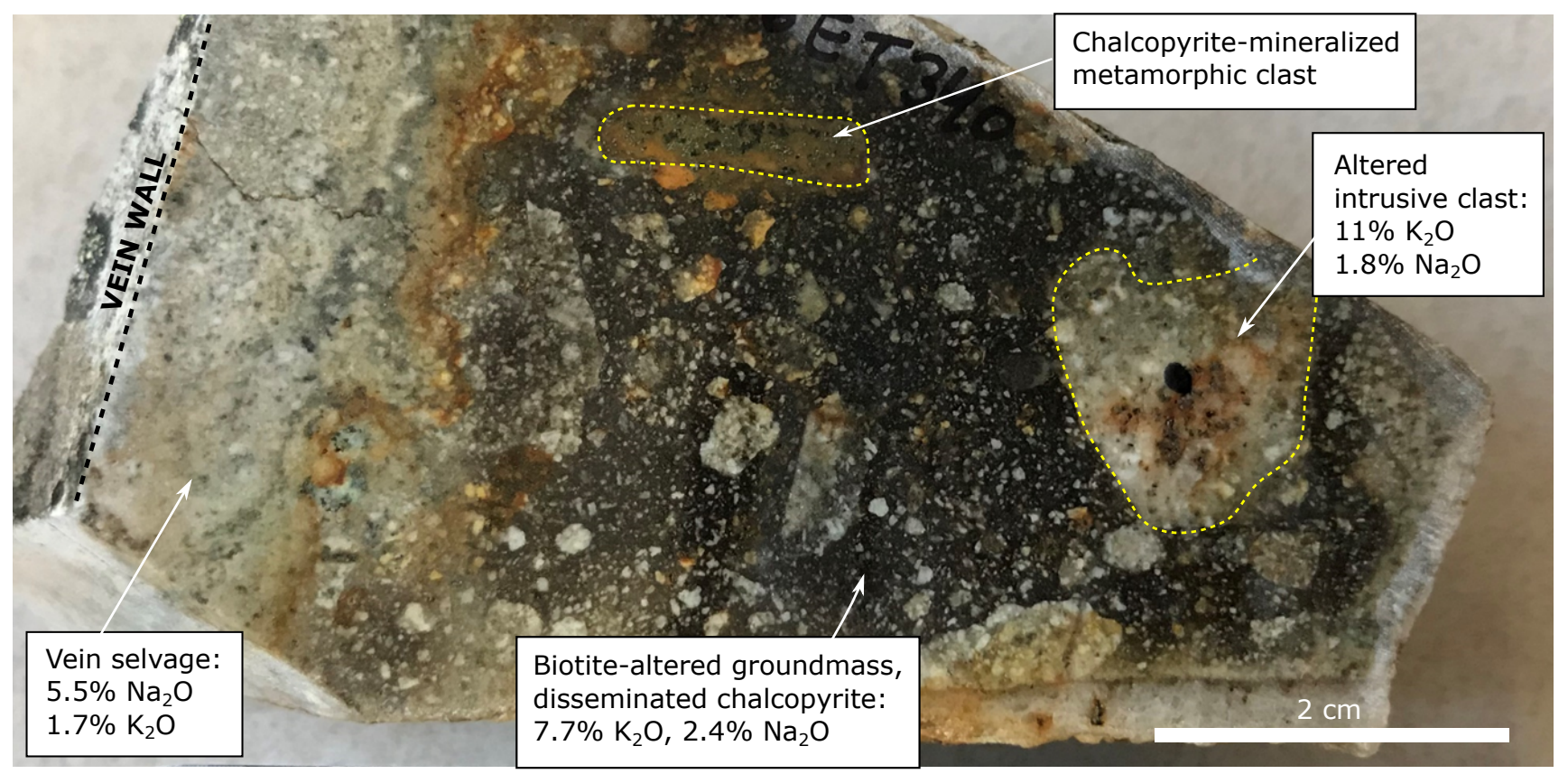

Figure 30. Hand sample showing altered and mineralized intrusion breccia at the Hona prospect. $\mathrm{K}_{2} \mathrm{O}$ and $\mathrm{Na}_{2} \mathrm{O}$ analyses are 8-mm spot analyses collected by handheld XRF.

x $10^{-3} \mathrm{SI}$; the highest values are from disseminated secondary pyrrhotite mineralization.

\section{Mineralization}

Mineralization at Hona is preferentially hosted by quartzite country rock along the northern margin of the stock and within about $100 \mathrm{~m}$ of the contact. Both disseminated sulfide and quartz-sulfide veinlet styles of mineralization are present. Disseminated mineralization is concentrated in decimeter- to multi-meter-thick bands that follow the metamorphic fabric of the quartzite (fig. 27A). Total sulfide content ranges from trace to 5 percent and is dominated by pyrite with lesser chalcopyrite. Pods of arsenopyrite occur within one strongly iron-stained (formerly pyritic) outcrop (fig. 27C, D); a sample of this material assayed $14.5 \mathrm{ppm} \mathrm{Au}$ and 19 percent As (15ET026; Wypych and others, 2015). Sparsely distributed veinlet-style mineralization displays vuggy textures (fig. 27B) and carries elevated $\mathrm{Au}$, $\mathrm{Ag}$, and $\mathrm{Cu}$ grades. Within the porphyritic intrusion, mineralization comprises both disseminated and veinlet-hosted styles, and the typical sulfide mineral assemblage is chalcopyrite and pyrrhotite. Molybdenite occurs locally within sub-centimeter quartz veinlets (fig. 28).

\section{Alteration}

Potassic alteration is locally developed near the northern contact of the Hona stock (fig. 28); this occurs as patchy to locally pervasive, very fine grained secondary biotite in the magmatic breccia (figs. 29, 30), and as local bands of K-feldspar replacement accompanying pyrite-chalcopyrite mineralization of the schistose country rock (fig. 28). K-feldspar-flooded clasts within biotite-altered groundmass (fig. 30) and pre-brecciation quartz veinlets preserved in clasts (fig. 29B) both suggest an extended or multiphase history of veining and alteration at Hona. Additionally, albitic alteration occurs locally in the selvages of late-forming quartz veinlets (fig. 30), although many such veinlets do not have albitic selvages. As with potassic alteration, albitic alteration locally replaces metamorphic country rock. Both potassic and albitic alteration may carry $\mathrm{Au}-\mathrm{Cu}$ mineralization. 

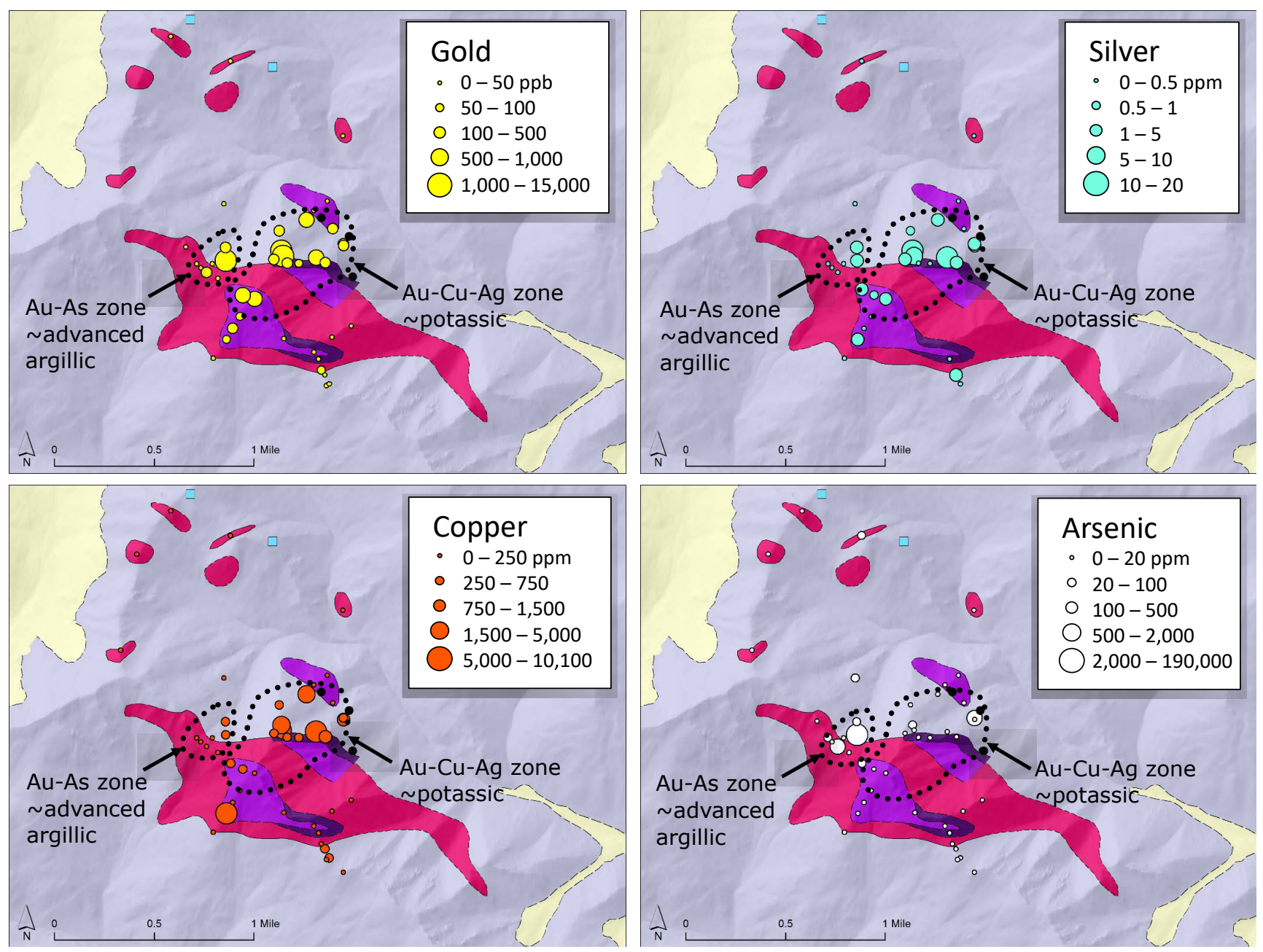

Figure 31. Map showing Au, Ag, Cu, and As geochemical data (Wypych and others, 2015, 2016) and alteration zones generalized from figure 28. See figure 25 for geologic legend.

Outside of the zone of secondary biotite alteration, a large portion of the Hona granodiorite intrusion is characterized by mafic minerals altered to an assemblage of chlorite, sericite, carbonate, and pyrrhotite (fig. 28). Very little of the granodiorite intrusion is unaltered. Some of the intrusions north of the main Hona stock are strongly affected by a barren assemblage of silicification and mafic mineral replacement by pyrrhotite.

A sample from near the western end of the Hona stock returned very low values of $\mathrm{K}, \mathrm{Na}$, and Ca relative to $\mathrm{Al}_{2} \mathrm{O}_{3}$, which is a geochemical indication of advanced argillic alteration (fig. 28). This sample assayed $0.129 \mathrm{ppm} \mathrm{Au,} \mathrm{1,430} \mathrm{ppm} \mathrm{As,} \mathrm{and}$ only 28 ppm Cu (15LF016; Wypych and others, 2015). Intense weathering might explain the depletion of alkalis and $\mathrm{Cu}$ but would not explain the high concentration of As, which is highly anomalous in the context of intrusion-hosted $\mathrm{Au}-\mathrm{Cu}$ mineralization at Hona.

\section{Ore and trace-element geochemistry}

Generally speaking, samples with elevated Au, $\mathrm{Cu}$, and $\mathrm{Ag}$ values occur in the same area around the center and northern contact of the Hona stock in a spatial pattern that is broadly similar to the distribution of biotite and K-feldspar alteration (fig. 31). $\mathrm{Au}$ and $\mathrm{Cu}$ are poorly correlated at the individual sample level (fig. 32A). $\mathrm{Ag}$ and $\mathrm{Cu}$ are 

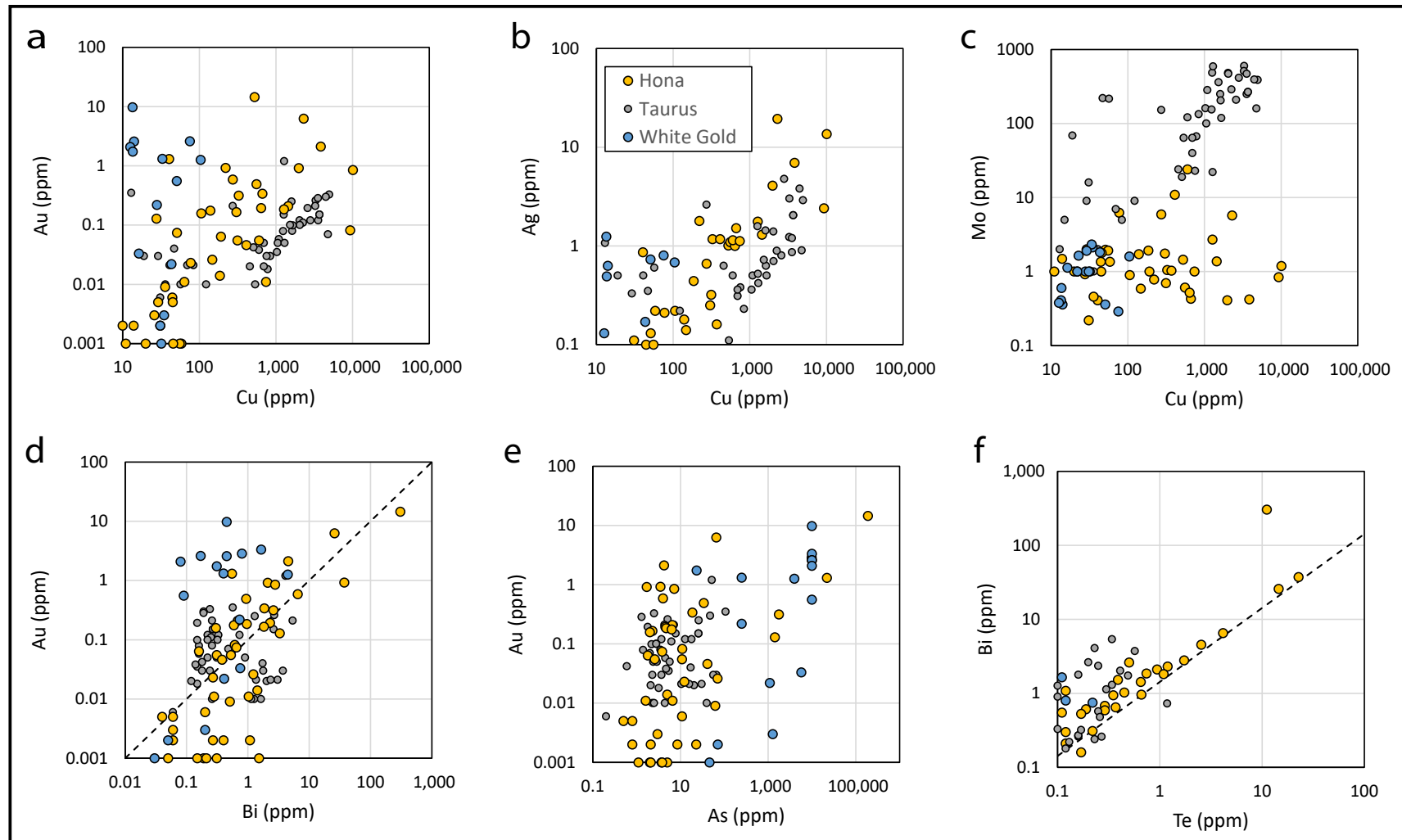

Figure 32. Bivariate scatter plots showing the concentration of selected elements at Hona, White Gold trend prospects Low and Shalosky (Wypych and others, 2015, 2016), and the Taurus Cu-Mo-Au porphyry system (Wypych and others, 2018). A. Cu vs. Au; (B) Cu vs. Ag; (C) Cu vs. Mo; (D) Bi vs. Au, showing the main trend of data at the Peak skarn (shaded gray; Illig, 2015) and the "Fort Knox trend" typical of reduced intrusion-related gold systems in Interior Alaska (Bi:Au = 10; McCoy and others, 1997); (E) As vs. Au; (F) Te vs. Bi, with dashed line indicating the Bi:Te ratio of the mineral hedlyite $\left(\mathrm{Bi}_{7} \mathrm{Te}_{3}\right)$; the outlier sample (15ET026) with high Bi must contain a different Bi phase.

better correlated, indicating that $\mathrm{Ag}$ may occur as a solid solution within chalcopyrite (fig. 32B). Bi shows general enrichment with $\mathrm{Au}$ at a Bi:Au ratio around 10:1 (fig. 32D). Bi and Te are very well correlated (fig. 32E), and their ratio suggests that a $\mathrm{Bi}$-Te mineral such as hedlyite $\left(\mathrm{Bi}_{7} \mathrm{Te}_{3}\right)$ may be the primary $\mathrm{Bi}$ and Te phase. An outlier, a gold-bearing arsenopyrite pod in pyritized schist (15ET026; Wypych and others, 2015), carries excess Bi and must contain another $\mathrm{Bi}$ phase (native $\mathrm{Bi}, \mathrm{Bi}_{2} \mathrm{~S}_{3}$, etc.). Two samples with elevated $\mathrm{Au}$ and As and little $\mathrm{Cu}$ or $\mathrm{Ag}$ occur towards the western end of the stock; these include the arsenopyrite pod and the aforementioned sample (15LF016) with apparent advanced argillic alteration. We tentatively interpret these samples to represent a separate "Au-As"' zone within the Hona system.

\section{Discussion}

We tentatively interpret the Hona stock to be a reduced, ilmenite-bearing type intrusion, despite not positively identifying primary ilmenite. We suggest this based on the low magnetic susceptibility of all intrusive phases, fresh or altered, which is consistent with the absence of magnetite. Further, pyrrhotite is the principle iron sulfide phase within the intrusion, whereas pyrite is typical in the adjacent mineralized metamorphic rock. These observations 
suggest that Hona is a reduced-type magmatic and hydrothermal system and that the low oxidation state is a characteristic of the intrusion rather than the influence of reducing country rocks at the site of emplacement.

Hona resembles the Peak skarn system in terms of age, geochemistry, mineralogy, and implied oxidation state. Intrusive rocks in the vicinity of Peak have similar major- and trace-element compositions to the Hona stock (fig. 33). The Peak skarn, site of the main $\mathrm{Au}-\mathrm{Cu}-\mathrm{Ag}$ resource on the Tetlin Reservation, is characterized by the ore mineral assemblage pyrrhotite-chalcopyrite-arsenopyrite-native bismuth-hedlyite-galena-sphalerite-gold (Illig, 2015). Pyrite does not occur at Peak, but it does occur elsewhere on the property. Silicate minerals are dominated by calcic amphiboles and relict Fe-rich clinopyroxene, averaging 70 to 80 percent hedenbergite component $\left(\mathrm{Hd}_{70-80}\right)$. Both silicate and sulfide assemblages at Peak indicate a low oxidation state for the mineralizing system (Illig, 2015). Further, the ore and trace-element profile for Peak (Au-Cu-Ag-As-Bi-Te) closely matches that of Hona. Skarn amphiboles at Peak yielded an ${ }^{40} \mathrm{Ar} /{ }^{39} \mathrm{Ar}$ plateau age of $72.1 \pm 0.5 \mathrm{Ma}$ (Illig, 2015), only slightly younger than the magmatic cooling ages determined for Hona (73.1 $\pm 0.9 \mathrm{Ma}$ and 75.8 $\pm 0.6 \mathrm{Ma}$; Benowitz and others, 2017).

There are important distinctions between the Hona stock and the Clearwater granodiorite pluton (fig. 2), which is similar in composition (fig. 33) and texture. The Clearwater pluton, elongate in the west-northwest direction, contains significant magnetite (magnetic susceptibility ranges from 3.5 to $17.5 \times 10^{-3} \mathrm{SI}$ ), indicative of a higher magmatic oxidation state. $\mathrm{U}-\mathrm{Pb}$ zircon dating of this intrusion yielded an age of $65.7 \pm 0.55 \mathrm{Ma}$ (Holm-Denoma and others, 2020), $10 \mathrm{Ma}$ younger than the hornblende age determined for Hona (Benowitz and others, 2017). The Clearwater intrusion is, to our knowledge, barren of mineralization and

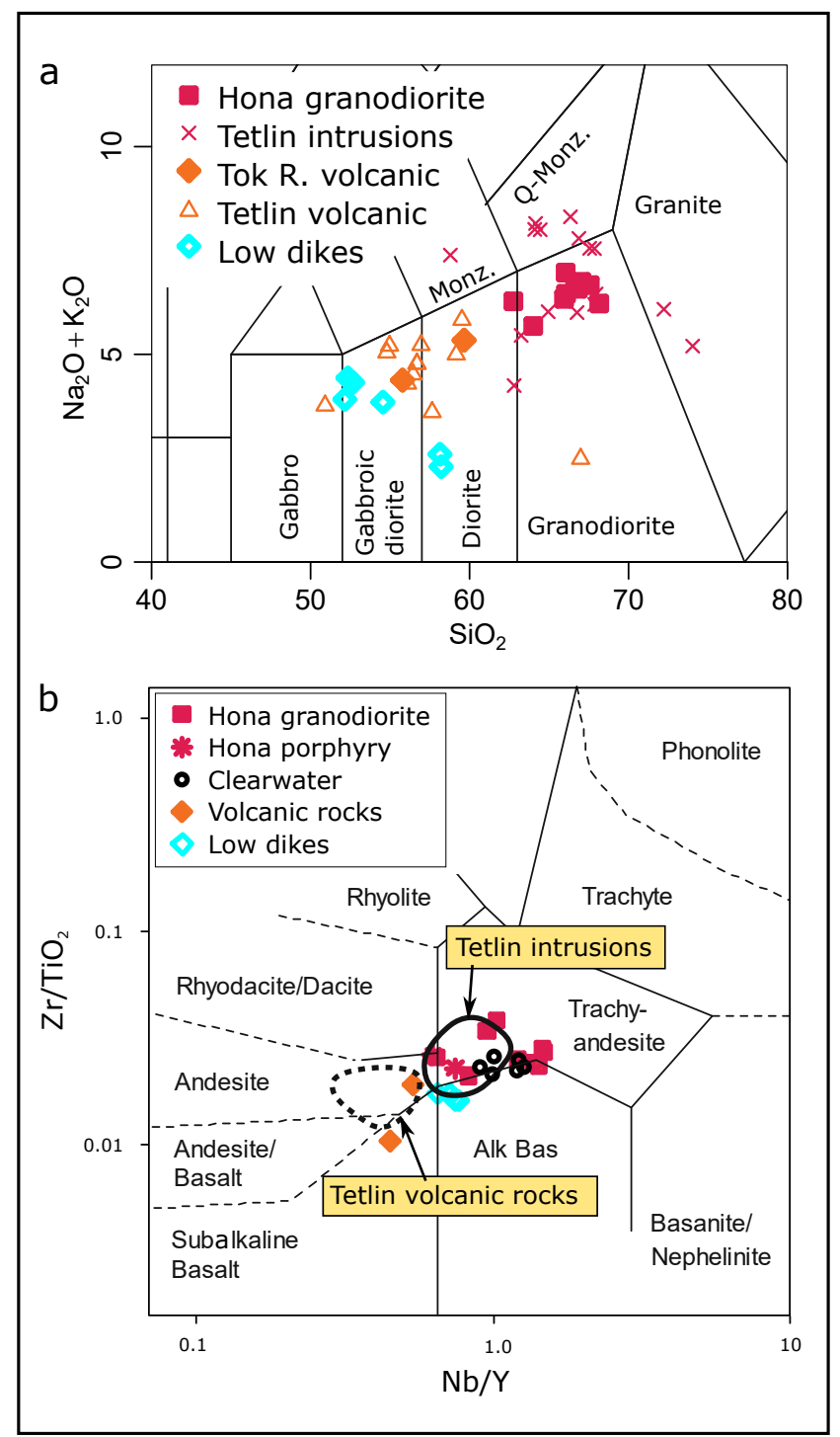

Figure 33. Geochemical classification diagrams showing the similarities between intrusive and volcanic rocks at Hona and the Tetlin property. A. Total alkalis vs. silica diagram of Middlemost (1994); (B) $\mathrm{Zr} / \mathrm{TiO}_{2}$ vs. $\mathrm{Nb} / \mathrm{Y}$ diagram of Winchester and Floyd (1976).

appears to be of a younger, higher-oxidation-state magmatic series despite some similarities to the Hona intrusions.

The only significant outcropping intrusion in the area of the Peak skarn, the quartz monzonite Mohawk pluton, is magnetite bearing (typical magnetic susceptibility values range from 1 to $8 \times 10^{-3}$ SI; Illig, 2015) and therefore indicates an 
oxidized-type magma. The age of this intrusion is $69.7 \pm 0.4 \mathrm{Ma}(\mathrm{U}-\mathrm{Pb})$, significantly younger than the age of Peak skarn amphiboles. In map view, the pluton is dike-like and elongate in the west-northwest direction (Illig, 2015). The Mohawk pluton may be analogous to the Clearwater pluton, a barren(?), oxidized-type pluton intruded shortly after deposition of reduced intrusion-related mineralization at Peak and Hona.

The Hona prospect resembles a copper porphyry system in several ways. The intrusions are hypabyssal, have porphyry textures, and indicate multiple phases of veining, alteration, and brecciation. Potassic alteration consisting of secondary biotite and local K-feldspar is developed towards the center of the stock and locally in the adjacent country rock. A chlorite-sericite-carbonate-pyrrhotite alteration halo, best described as propylitic, affects the majority of the intrusion outside of the potassic zone.

However, Hona is different from the traditional porphyry model in several important ways. The intrusion is apparently reduced, rather than oxidized, and the iron sulfide phase within the intrusion is exclusively pyrrhotite instead of pyrite. The low oxidation state of the system offers an explanation for the lack of a well-developed sericitic alteration zone. This assemblage is generated by disproportionation of $\mathrm{SO}_{2}$ gas (the existence of which requires a high oxidation state) to form sulfuric acid, which reacts with feldspar to form sericite and quartz, and $\mathrm{H}_{2} \mathrm{~S}$, which ultimately forms pyrite (Seedorff and others, 2005).

Levels of certain trace elements, including $\mathrm{As}, \mathrm{Bi}, \mathrm{Te}$, and $\mathrm{Co}$, are significantly more enriched than would typically be found in a porphyry copper deposit (e.g., Halley and others, 2015). Compared with the coeval Taurus porphyry $\mathrm{Cu}-\mathrm{Mo}-\mathrm{Au}$ prospect $120 \mathrm{~km}$ to the northeast (ca. $72 \mathrm{Ma}$, based on $\mathrm{U}-\mathrm{Pb}$ zircon dating at the nearby Bluff prospect; Allan and others, 2013), Hona has much lower Mo values, but is enriched in $\mathrm{Ag}, \mathrm{Au}, \mathrm{Bi}, \mathrm{Te}$, and $\mathrm{As}$ (fig. 32). Instead, Hona has a Bi:Au ratio broadly similar to that of the Peak skarn and intrusion-related gold mineralization in the Fairbanks district (fig. 32D).

The magmatic-hydrothermal system at Hona is clearly fertile for formation of $\mathrm{Au}(\mathrm{Cu}-\mathrm{Ag})$ mineralization. While the mineralization that we observed in the field was likely subeconomic, the system has partial similarity with the Peak skarn deposits. At Peak, several potentially economic orebodies formed where country rock marble interacted with mineralizing hydrothermal fluids. Mapping by DGGS (Sicard and others, 2017) shows that such marble layers occur in the Hona vicinity approximately 1 $\mathrm{km}$ north of the main intrusive stock (fig. 25).

\section{Structurally controlled gold mineralization}

The White Gold trend of the Tok River area (not to be confused with the more recently named White Gold district in Yukon) comprises largely structurally controlled gold mineralization north of Dry Tok Creek and south of the upper Tok River (fig. 34). These prospects form a northeast-trending cluster that is broadly associated with a northeast-trending fault and associated splays (fig. 34; Dashevsky and others, 2003; Sicard and others, 2017).

DGGS did not conduct geologic mapping or other in-depth work in the White Gold trend; however, we briefly visited and sampled the Shalosky, Low, and Goldberg prospects in order to address questions regarding the timing and geologic controls on mineralization. We also visited Sam's Slab, a similarly styled gold prospect in the Robertson River drainage, as well as several of the AR trend prospects north of the Tok River (fig. 2).

There are two likely models to explain the structurally controlled gold mineralization of the Tok River area. According to the first, the orogenic gold model (e.g., Goldfarb and others, 2005), hydrothermal fluids arise from devolatilization 
of structurally lower rocks during prograde metamorphism. In this case, mineralization would be Permian to Jurassic in age, and any association with intrusive rocks would be merely incidental. Another possible model is the intrusion-related gold model (e.g., McCoy and others, 1997), involving hydrothermal fluids and/or heat derived from coeval intrusions. Mineralization may occur within or adjacent to the intrusion ("proximal"; Fort Knox, Hona), or at an unknown distance from a hypothetical intrusion ("distal"; Pogo, Clearly Hill veins, schist-hosted mineralization at Ryan Lode). In this case, mineralization would most likely be Late Cretaceous to Paleocene in age, similar to the age of intrusive rocks in the area.

Our work in the area, described below, suggests that structurally controlled mineralization in the Tok River area occurred well after metamorphic cooling, likely during the Paleogene. Mafic to felsic dikes accompany gold mineralization at some prospects. Locally, these dikes occupy the same structures as gold mineralization, are both pre-/syn- or post-mineralization in timing, and are themselves weakly mineralized and altered by advanced argillic alteration.

\section{Shalosky prospect}

At the Shalosky prospect, a stream cut exposes a gold-bearing quartz vein and shear zone averaging $3.9 \mathrm{ppm}$ Au over $16.4 \mathrm{~m}$ from hand trenching. The vein trends east-northeast, has a subvertical dip, and has been traced approximately $600 \mathrm{~m}$ in drilling and trenching (Rhyolite Resources, 2019). DGGS sampled bleached and silicified, white mica-bearing material

Figure 34. Inset of geologic map (Sicard and others, 2017) of the White Gold trend of structurally controlled gold prospects. See figure 2 for legend. from near the center of the shear zone in an attempt to obtain an ${ }^{40} \mathrm{Ar} /{ }^{39} \mathrm{Ar}$ age of mineralization.

Petrography (fig. 35) shows that the sample retains a metamorphic fabric and is a bleached metamorphic wallrock inclusion rather than hydrothermal quartz-white mica vein material. Nevertheless, this rock was exposed to hydrothermal alteration that appears to have partially reset the ${ }^{40} \mathrm{Ar} /{ }^{39} \mathrm{Ar}$ spectrum of the sample (fig. 35; Benowitz and others, 2017). The spectrum exhibits a stair-step pattern, with the highest-power step (interpreted as the cores of the grains analyzed) yielding an age of $114 \mathrm{Ma}$, and the lowest-power step (grain rims) yielding an age of $83 \mathrm{Ma}$. The highest-power step approaches the cooling age of metamorphic micas in the Tok River area, approximately 125 $\mathrm{Ma}$ (Benowitz and others, 2017). We interpret the lowest-power step to reflect reset by hydrothermal fluids after $83 \mathrm{Ma}$, circumstantial evidence that gold

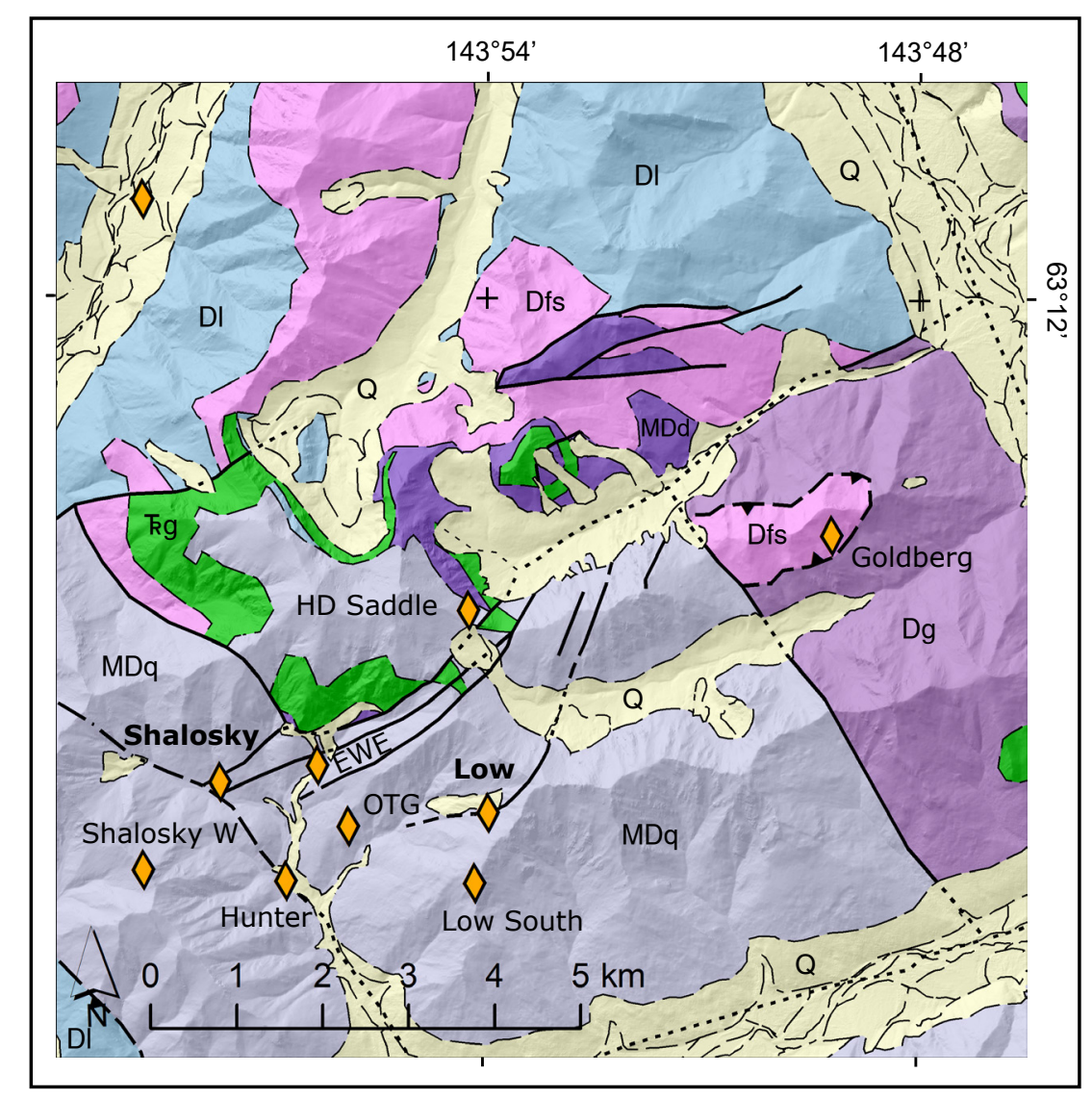


mineralization is not synchronous with prograde regional metamorphism.

\section{Low prospect}

The Low prospect is unique among the prospects of the White Gold trend in that mafic and felsic dikes occur in the immediate prospect area and are spatially associated with mineralization. The prospect offers an opportunity to evaluate whether a temporal and/or genetic relationship exists between intrusions and mineralization in the district.

As described by Rhyolite Resources (2019), the Low zone primarily comprises structurally controlled mineralization in quartz-sulfide veinlets, brecciation, and fault gouge in a steeply dipping, east-west-trending shear. The most significant mineralization is of this style, including a hand trench intercept averaging $13.37 \mathrm{ppm}$ Au over 3 $\mathrm{m}$. Drilling by Rhyolite Resources also intercepted altered and mineralized dikes carrying lower, but still significant, gold grades.

Our brief visit to the Low prospect, followed by an examination of drill core, indicates that post-metamorphic, north-south-trending, high-angle mafic and felsic dikes (fig. 36) are spatially associated with mineralization. Some of these are altered and mineralized; therefore, we are able to conclude that they are pre- to syn-mineral.

Microprobe analyses indicate the alteration assemblage associated with Au-As-mineralized dikes is kaolinite-quartz-ankerite- $\mathrm{Mg}$ sideriterutile \pm minor muscovite \pm albite; the sulfide assemblage is arsenopyrite-pyrite. This assemblage indicates advanced argillic alteration and is not a product of weathering.

We sampled mineralized and unmineralized dikes from drill core for lithogeochemical analyses. Mafic dikes form a distinctive compositional cluster in terms of immobile trace elements, including REE (fig. 37) and high-field-strength elements (fig. 33B). These "Low-type" dikes may be Au-As mineralized and altered to advanced argillic assemblage, or unmineralized with only minor calcite alteration; figure 36C shows one locality in drill core where we observed a weakly altered dike crosscutting an altered and mineralized one.

"Low-type" mafic dikes, as classified by immobile trace elements, also occur outside of the

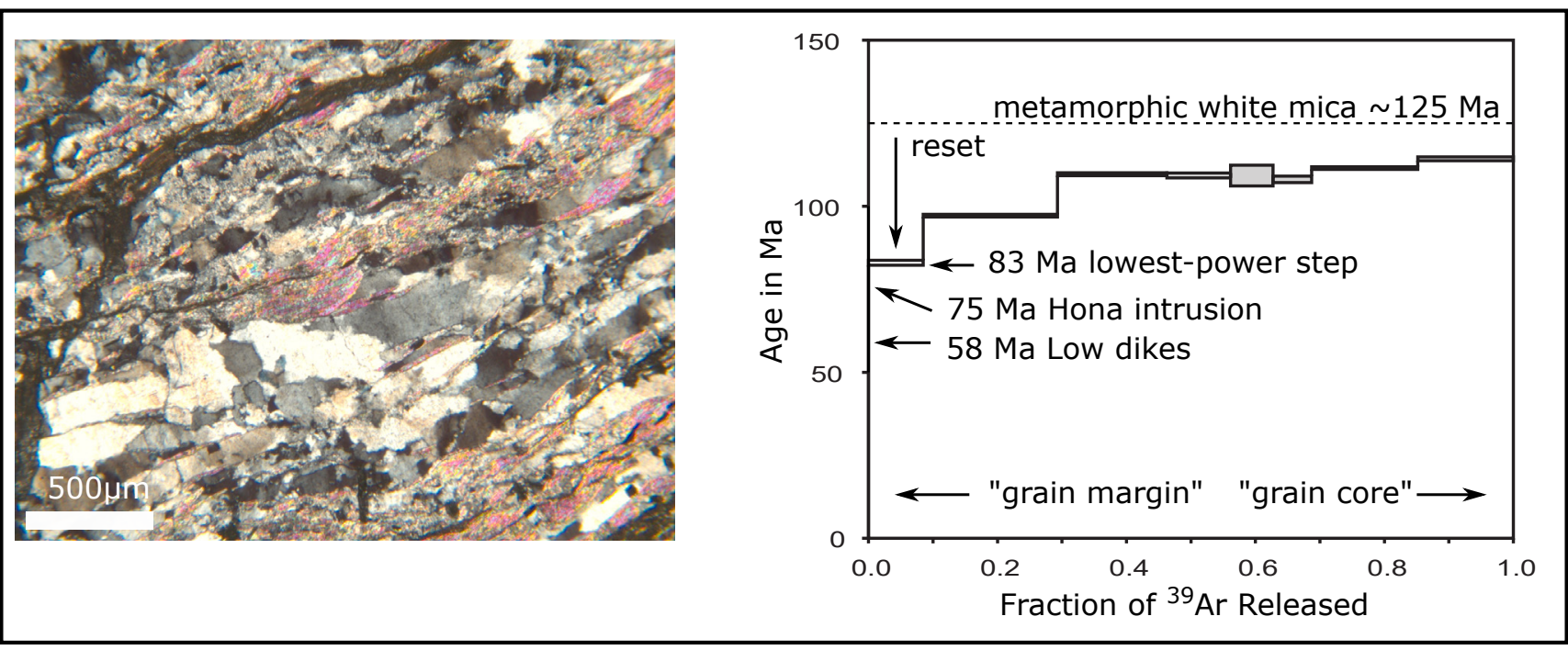

Figure 35. Left: photomicrograph (XPL) of bleached metamorphic wallrock inclusion (sample 15ET005) within the Shalosky gold-mineralized quartz vein and shear zone. Right: ${ }^{40} \mathrm{Ar} /{ }^{39} \mathrm{Ar}$ spectrum diagram of this sample showing the stair-step pattern interpreted as partial rest after $83 \mathrm{Ma}$. 
prospect area. Benowitz and others (2017) dated one such dike approximately $10 \mathrm{~km}$ south of the Low prospect; this dike yielded a biotite ${ }^{40} \mathrm{Ar} /{ }^{39} \mathrm{Ar}$ plateau age of $58.4 \pm 0.3 \mathrm{Ma}$. We infer that this age is applicable to the dikes at the Low prospect based on the close similarity in trace elements.

Because weakly altered Low-type dikes crosscut altered and mineralized Low-type dikes in core (fig. 36C), we suggest that mineralization occurred within the time frame of emplacement of this suite of dikes around $58 \mathrm{Ma}$. This makes the mineralization at Low significantly younger than the ca. 73 Ma intrusion-related gold mineralization at Hona and the Peak skarn. Other key differences between Hona and White Gold include a clear intrusive association at Hona versus an ambiguous intrusive association at Low, and significant differences in the trace-element profile of White Gold mineralization, which is comparable to Hona's in terms of As but much lower in $\mathrm{Bi}, \mathrm{Te}, \mathrm{Ag}, \mathrm{Cu}$, and Mo (fig. 32).

\section{Sam's Slab}

The occurrence known as Sam's Slab was discovered in 2006 by Northern Associates Inc. geologist Sam Dashevsky during mapping and exploration of VMS mineralization in the Delta mineral belt and relocated by DGGS during 2016. It is a particularly
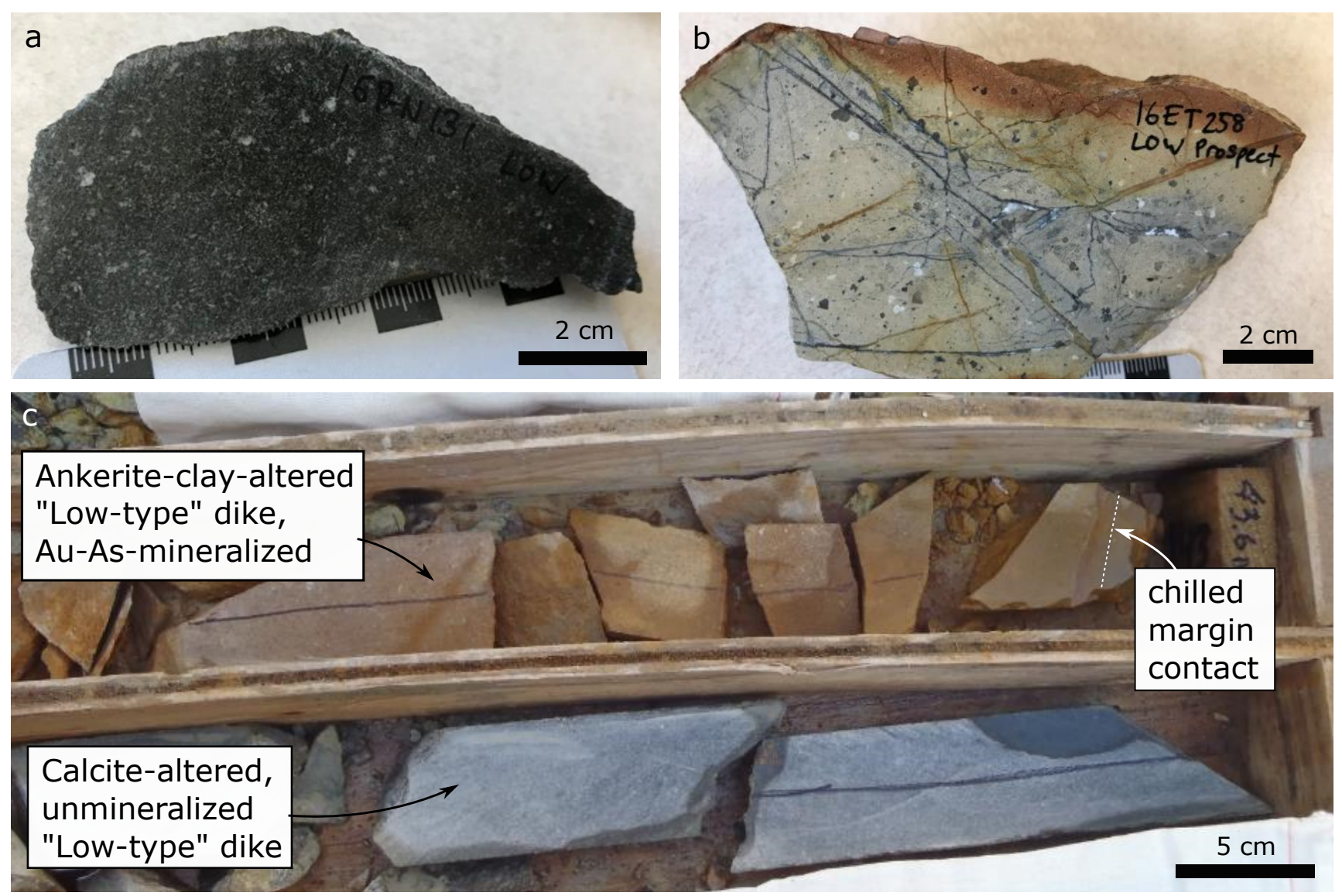

Figure 36. Dikes from the Low prospect: (A) unaltered, biotite-rich "lamprophyre" dike; (B) quartz-feldspar porphyry dike containing quartz-arsenopyrite-pyrite veinlets, disseminated arsenopyrite, and ankerite alteration; this sample assayed 33 ppb Au, 5,700 ppm As, and 39 ppm Sb (16ET258; Wypych and others, 2016); (C) Low prospect core showing two "Low-type" dikes in a crosscutting relationship; an unmineralized, calcite-altered dike cuts a mineralized dike assaying 219 ppb Au and 250 ppm As, which is altered to a kaolinite-quartz-ankerite-siderite assemblage (16RN165D; Wypych and others, 2016). 


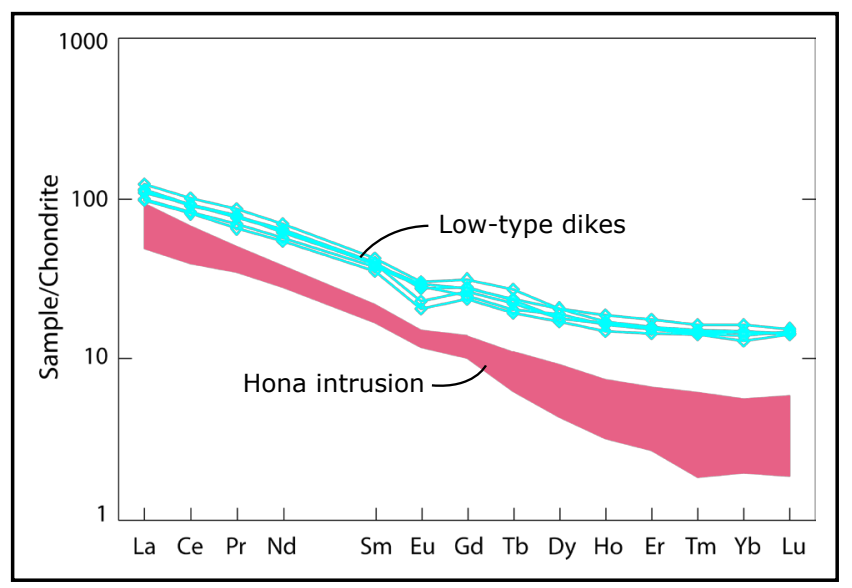

Figure 37. Chondrite-normalized REE diagram after Boynton (1984) showing samples from the Hona intrusion and "Lowtype" dikes, dated at 58.4 $\pm 0.3 \mathrm{Ma}$ (16KS215; Benowitz and others, 2017).

visual example of gold mineralization in the Tok River area (fig. 38). It is located at an elevation of approximately $4,700 \mathrm{ft}$ on an east-facing hillslope above an unnamed tributary to the Robertson River between Rumble Creek and Tushtena Pass.

The occurrence comprises a tabular, weakly banded, coarse-grained milky quartz vein carrying trace galena and chalcopyrite. A 34-cm chip sample across the width of the vein assayed $2.19 \mathrm{ppm}$ $\mathrm{Au}$ and $11.9 \mathrm{ppm} \mathrm{Ag}$, plus anomalous Bi (9.68 ppm; 16ET275; Wypych and others, 2016). The vein has at least $30 \mathrm{~m}$ of estimated continuity in outcrop at this thickness, and is paralleled on its southern contact by an approximately 5 -m-thick altered plagioclase-biotite porphyry dike (fig. 38). The alteration consists of weak pyritization, ankerite-clay alteration, and chloritization of mafics, but assays of the dike indicate only weak enrichment in As (58.5 ppm; 16ET276; Wypych and others, 2016). The dike contains abundant inclusions of foliated siliceous schist country rock, indicating post-metamorphism emplacement.

Both the vein and the dike strike approximately 103 degrees azimuth and dip 67 degrees towards the south. An iron-oxide-stained alteration zone (possibly including the parallel dike) continues westward to the ridgeline.

The vein and dike at this occurrence are hosted by calcareous quartz-sericite-chlorite schist of the Tushtena Pass unit of the Jarvis belt (Dashevsky and others, 2003). The dike may be associated with one of the two suites of dikes recognized by Foley (1984) with mid-Cretaceous (76-118 Ma) or CretaceousTertiary (63-69 Ma) ages, or it may be similar to the kaolinite-ankerite-siderite-altered dikes at the Low prospect, which are geochemically correlated to a dike dated at $58.4 \mathrm{Ma}$, as discussed above.

\section{$\mathrm{Pb}$ isotope data}

We submitted a representative group of sample pulps to ALS Minerals for $\mathrm{Pb}$ isotopic ratio analysis by ICP-MS (method code PbIS-RAT61). The results are shown in table 9 and figure 39 . The ICP-MS method analyzes whole-rock pulps rather than mineral separates, and it requires only $2 \mathrm{ppm}$ $\mathrm{Pb}$ to be present in the sample. In contrast to our base-metal prospect samples, we did not identify a Pb-bearing phase in the gold prospect samples. Therefore, we selected samples containing anomalous $\mathrm{Au}$ or As occurring with anomalous $\mathrm{Pb}$ since our intention was to measure the $\mathrm{Pb}$-isotopic ratios of mineralization. The selected samples also have $\mathrm{Pb}$ much greater than $\mathrm{U}$ and $\mathrm{Th}$, so we infer that the $\mathrm{Pb}$-isotopic ratios reflect $\mathrm{Pb}$-bearing minerals.

$\mathrm{Pb}$-isotopic ratios from the gold prospects indicate (with the exception of the Hona sample) a broadly Mesozoic or younger age for $\mathrm{Pb}$ mineralization and a variety of $\mathrm{Pb}$ sources (fig. 39). The dikehosted sample from the Low prospect (22 ppb Au, 1,095 ppm As; 16RN172F; Wypych and others, 2016) is very similar to mid-Cretaceous intrusion-related gold systems at the Peak skarn (Illig, 2015) and in the Fairbanks district (Newberry and others, 1988). Sam's Slab has relatively low radiogenic Pb, closer to mantle values. Samples from Shalosky, also part of the White Gold property, and the nearby, 


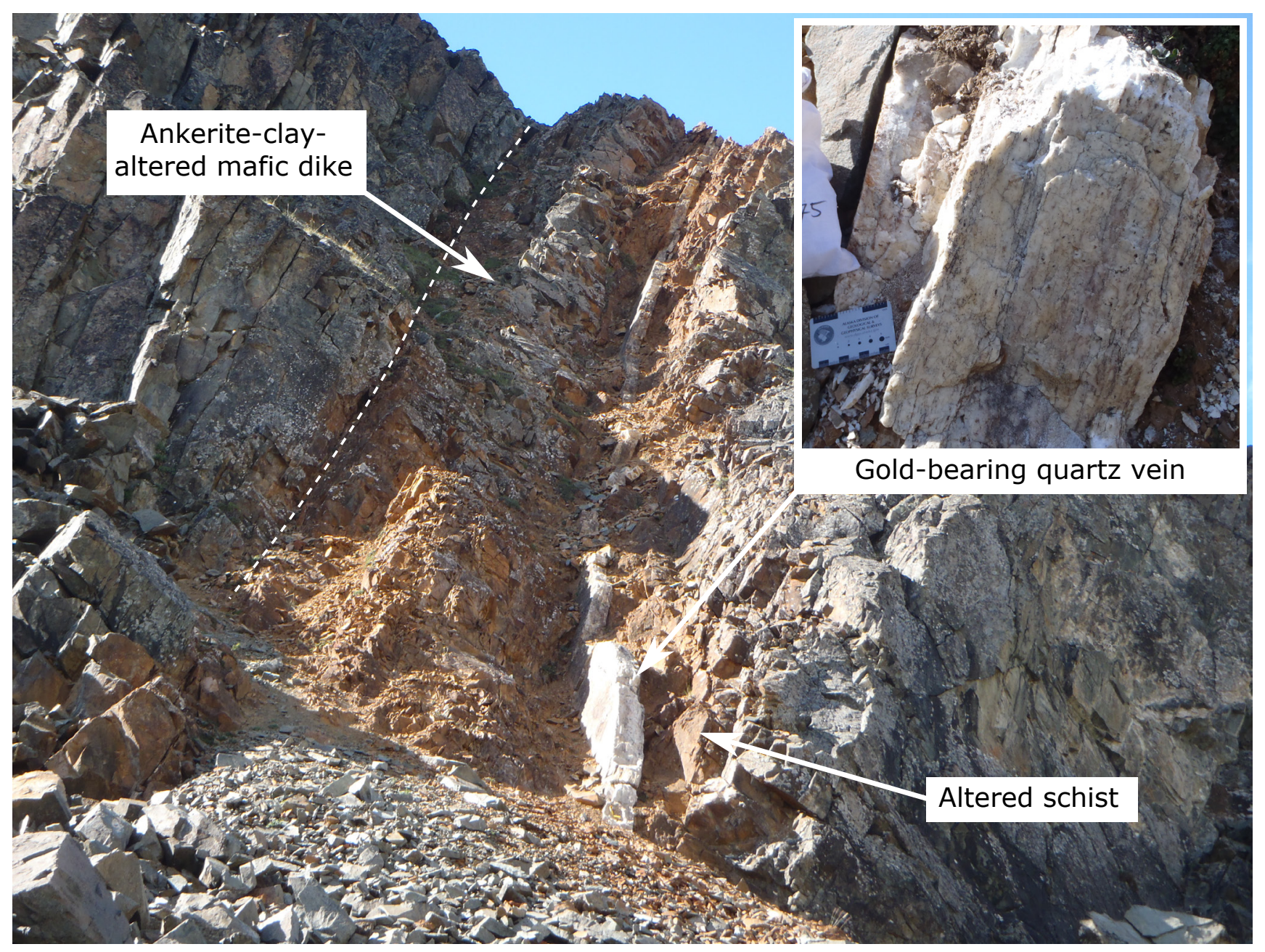

Figure 38. Sam's Slab quartz vein, parallel dike, and altered country rock. Photo looking west. The vein is $34 \mathrm{~cm}$ thick at the site of sample 16 ET275 (foreground, and inset at upper right); the dike is approximately 5 m thick.

structurally controlled RS prospect on the AR trend have very high radiogenic $\mathrm{Pb}$. These ratios are consistent with $\mathrm{Pb}$ sourced from radiogenic upper crust, such as the continentally derived siliciclastic metasedimentary rock of the Lake George assemblage, which contains abundant Paleoproterozoic and Archean detrital zircons (Dusel-Bacon and others, 2017). They are also similar to the Jurassic orogenic gold veins in the Klondike region (fig. 39; Mortensen and others, 1992) but much more radiogenic than the Fairbanks-area vein-hosted mineralization (Newberry and others, 1988). The sample from Hona, a siliceous schist carrying 2 percent disseminated pyrite, $339 \mathrm{ppb} \mathrm{Au}, 667 \mathrm{ppm} \mathrm{Cu}$, and $55 \mathrm{ppm} \mathrm{Pb}$ (16RN166; Wypych and others, 2016), has Pb-isotopic ratios very similar to those of Devonian to Mississippian stratabound base-metal mineralization. Elevated $\mathrm{Pb}$ is not typical of Hona $\mathrm{Au}-\mathrm{Cu}$ mineralization, and the $\mathrm{Pb}$-isotopic ratios seem to indicate this sample received its $\mathrm{Pb}$ mineralization during the Paleozoic.

\section{Discussion}

The timing of structurally controlled gold mineralization is indirectly constrained by geochemical correlation of syn-mineralization(?) dikes at the Low prospect to a nearby dike dated at $58 \mathrm{Ma}$; this age is consistent with partial resetting of metamorphic micas at $83 \mathrm{Ma}$ or younger at the Shalosky 
prospect. If our interpretation of a Paleogene age is correct, the White Gold prospects are well separated in time from ca. $73 \mathrm{Ma}$ intrusion-related gold mineralization at Hona, and much younger than mid-Cretaceous intrusion-related gold mineralization in the Fairbanks and Goodpaster districts. In Interior Alaska, the period 61 to $55 \mathrm{Ma}$ is characterized by widespread extensional tectonics and bimodal magmatism (Newberry, 2000).

The presence of advanced argillic alteration accompanying gold mineralization at the Low prospect indicates highly acidic hydrothermal fluids. Intense clay alteration and local silicification also occur in association with lower-grade gold mineralization at Shalosky (Rhyolite Resources, 2019).
Kaolinite-bearing advanced argillic alteration is known to occur at intrusion-related gold deposits in Interior Alaska (e.g., Livengood [Nichols, 2013], Dolphin [Raymond, 2018], etc.); however, it is not associated with orogenic gold deposits (Goldfarb and others, 2005).

The minimal $\mathrm{Pb}$ isotope dataset presented here does not conclusively support either an intrusion-related or orogenic deposit model. $\mathrm{Pb}$ mineralization in or immediately adjacent to dikes seems to indicate a possible intrusive origin; however, dike-associated mineralization is found only locally on the White Gold trend, so it is reasonable to conclude that the majority of $\mathrm{Pb}$ mineralization is derived from a more radiogenic metasedimentary source.

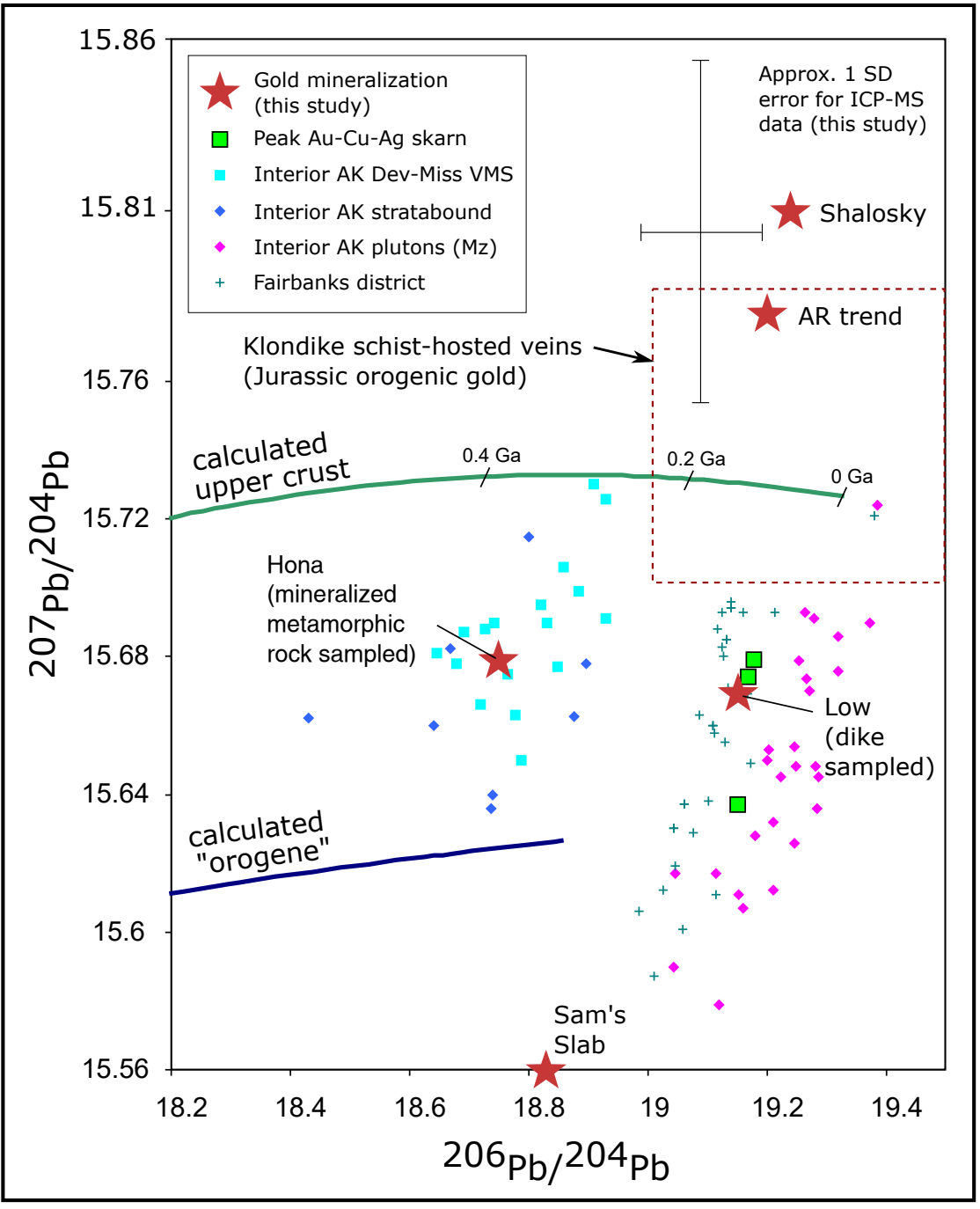

Figure 39. ICP-MS Pb isotopic data from gold prospects in the Tanacross A- 5 and A-6 quadrangles plotted against data from the nearby Late Cretaceous Peak Au-CuAg skarn, Jurassic orogenic gold systems in Yukon, and Devonian to Mississippian VMS occurrences, including the Delta mineral belt. Also shown are stratabound base-metal occurrences (Paleozoic), plutons (Mesozoic), and the mid-Cretaceous intrusion-related gold mineralization in the Fairbanks mining district. Comparative data are compiled from Illig (2015), Aleinikoff and others (1987), Gaccetta and Church (1989), Godwin and others (1988), Newberry and others (1988), and Mortensen and others (1992). 
A possible regional analog for the White Gold trend is the Hajdukovich property located $72 \mathrm{~km}$ northwest near Delta Junction. Both properties are associated with regional, northeast-trending faults and lie similar distances north of the Denali fault. Hajdukovich is spatially associated with, and possibly related to, an early Tertiary (56 Ma) alkalic intrusive complex (Avalon Development Corp., 2015). However, as with the White Gold prospects, the mineralization is structurally controlled and hosted by gold-bearing low-sulfide quartz veins and breccias.

\section{CONCLUSIONS}

\section{Base-metal sulfide mineralization}

Base-metal ( $\mathrm{Zn}-\mathrm{Pb}-\mathrm{Cu}-\mathrm{Ag}-\mathrm{Au})$ sulfide prospects of the Tanacross A-6 Quadrangle are stratabound and formed by partial to complete replacement of marble layers within a volcanic-poor metasedimentary sequence of Devonian to Mississippian age.

Sulfide mineralization formed prior to Permian through Jurassic regional metamorphism. Sphalerite (with the assemblage pyrite-pyrrhotite) has 11.2 to 14.6 molecular percent FeS, consistent with greenschist facies pressures and temperatures, and ore minerals are locally involved in metamorphic fabrics. Pb-isotopic ratios are closely similar to those of Devonian to Mississippian base-metal deposits, and they are clearly distinguishable from nearby Cretaceous skarn mineralization on the Tetlin Reservation.

The unusual gangue silicate mineralogy (Fe-clinopyroxene, Ca-Mn garnet, stilpnomelane, ferro-actinolite, ilvaite) is the product of Fe-MnCa-rich rock compositions plus regional metamorphism. Some mineralogical and textural evidence and geothermometry indicate that the Tanacross A-6 Quadrangle prospects may have been metamorphosed to higher grades than the PP-LZ trend or the Delta mineral belt.

The Tanacross A-6 Quadrangle base-metal prospects of the Eagle trend are a southeasterly continuation of the PP-LZ trend. PP-LZ trend mineralization may be hosted by either carbonate layers or by graphitic metasedimentary rocks; our work found only the carbonate-hosted style of mineralization continuing into the Tanacross A-6 Quadrangle.

The most appropriate deposit model for the Tanacross A-6 Quadrangle base-metal mineralization may be a variant of the sedimentary-exhalative (SEDEX) model, such as Irish-type $(\mathrm{Cu})-\mathrm{Zn}-\mathrm{Pb}$.

\section{Gold mineralization}

The Hona prospect is hosted by a multiphase hypabyssal stock of granodiorite composition. Mappable phases include holocrystalline granodiorite, intruded by granodiorite porphyry and magmatic breccia. The low-magnetic susceptibilities of unaltered intrusive rocks suggest the magmas forming the stock were of reduced character.

Multiple phases and styles of alteration and veining are evident, including potassic (secondary biotite alteration of intrusive rock and localized K-feldspar alteration of country rock) and propylitic (chlorite-sericite-carbonate alteration of intrusive rock) styles, plus local silicification, albitization, and argillic alteration.

The sulfide assemblage within the intrusive stock is pyrrhotite \pm chalcopyrite \pm molybdenite. Mineralized country rock adjacent to the stock is dominated by pyrite \pm chalcopyrite \pm arsenopyrite.

The Hona intrusive stock is closely similar in age and trace-element composition to the intrusions on the Tetlin property. The geochemical profile (Au-Cu-Ag-As-Bi-Te) and the pyrrhotite-rich sulfide assemblage of Hona mineralization are also similar to those of the Peak skarn on the Tetlin property.

At the structurally controlled gold prospects in the study area, advanced argillic alteration affects dikes at Low, and mineralization at Shalosky occurs with clay alteration. These acidic alteration styles 
are best explained as the effects of magma-derived sulfuric acid. $\mathrm{Pb}$-isotopic ratios suggest a mix of radiogenic and magmatic $\mathrm{Pb}$ sources for some of the gold prospects in the Tok River area. Taken together, the data seem to suggest a hydrothermal system driven by intrusive rocks (mostly "at depth" and not outcropping), with contributions of magmatic volatiles and metal derived from both metamorphic and intrusive rocks.

Partially reset white mica from the Shalosky prospect indicates a maximum age of $83 \mathrm{Ma}$, and mafic dikes at Low correlate geochemically to a dike dated at $58 \mathrm{Ma}$. We interpret these ages to indicate a Paleocene age for gold mineralization on the White Gold trend. This age is significantly younger than the age of Hona, but it is similar to the age of the similarly styled Hajdukovich gold property.

\section{ACKNOWLEDGMENTS}

We thank Ahtna Inc. and its officers Joe Bovee and Heidi Lingenfelter for access to corporation lands and geological data in the study area. We recognize the discoveries and the high-quality reporting of Clint Degenhart and the 1977-78 WGM Inc. exploration crew; these were critical to the success of this project. Northern Associates Inc., Rhyolite Resources Ltd., and Agnico Eagle Mines Ltd. granted access to core and contributed data for comparative purposes. Samuel S. Dashevsky, Carl
F. Schaefer, John E. Hoppe, David J. Szumigala, Lawrence K. Freeman, and Peter E. Illig contributed valuable geological discussions. We thank George Case and Jennifer E. Athey for constructive reviews of this report

This project would not have been possible without the field contributions of DGGS geologists Larry K. Freeman, Melanie B. Werdon, Lauren L. Lande, David A. Reioux, Amanda L. Willingham, Robert J. Gillis, and Trent D. Hubbard. Alexandra C. Busk and Kurt J. Johnson assisted with samples at the Geological Materials Center. Soloy Helicopters pilots Sam Gawaith and Frank Ross flew us safely to and from the field, and John and Jill Rusyniak of Log Cabin Wilderness Lodge made sure that we were well fed and comfortable.

This project is jointly funded by the State of Alaska's Strategic and Critical Minerals Assessment Project (part of DGGS's Airborne Geophysical/ Geological Mineral Inventory program), a USGS Mineral Resources Assessment Grant G16AS00003, and the USGS National Cooperative Geologic Mapping Program, STATEMAP component, under award G16AC00182 for 2016. The views and conclusions contained in this document are those of the authors and should not be interpreted as necessarily representing the official policies, either expressed or implied, of the U.S. Government. 


\section{REFERENCES}

Aleinikoff, J.N., Dusel-Bacon, Cynthia, Foster, H.L., and Nokleberg, W.J., 1987, Lead isotopic fingerprinting of tectono-stratigraphic terranes, east-central Alaska: Canadian Journal of Earth Sciences, v. 24, p. 2,089-2,098.

Allan, M.M., Mortensen, J.K., Hart, C.R, Bailey, L.A., Sanchez, M.G., Ciolkiewicz, Wiltold, McKenzie, G.G., and Creaser, R.A., 2013, Magmatic and metallogenic framework of west-central Yukon and eastern Alaska, in Colpron, Maurice, Bissig, Thomas, Rusk, B.G., and Thompson, J.F.H., Tectonics, Metallogeny, and Discovery: The North American Cordillera and Similar Accretionary Settings, Society of Economic Geologists, Special Publication 17, p. 111-168.

Avalon Development Corporation, 2015, Hajdukovich Project Summary Report: Unpublished report at http://www.avalonalaska. com/Hajd-2015-Summary-1.pdf (accessed April 3, 2018).

Benowitz, J.A., Sicard, K.R., Naibert, T.J., and Layer, P.W., 2017, ${ }^{40} \mathrm{Ar} /{ }^{39} \mathrm{Ar}$ data from the Tok River area, Tanacross A-5 and A-6 quadrangles and adjoining areas, eastern Alaska Range: Alaska Division of Geological \& Geophysical Surveys Raw Data File 2017-5, 26 p. http://doi.org/10.14509/29727

Boynton, W.V., 1984, Cosmochemistry of the rare earth elements; meteorite studies, in Henderson, Paul, ed., Rare earth element geochemistry: Amsterdam, Elsevier Scientific Publishing Company, p. 63-114.

Colpron, Maurice, and Nelson, J.L., 2011, A digital atlas of terranes for the Northern Cordillera: British Columbia Ministry of Energy, Mines, and Petroleum Resources, GeoFile 2011-11. http://www.empr.gov.bc.ca/Mining/Geoscience/ PublicationsCatalogue/GeoFiles/Pages/2011-11. aspx

Culp, S.L., 1982, Geology and Mineralization of the PP-LZ Massive Sulfide Horizon, East-Central Alaska Range, Alaska, Fort Collins, Colorado State University, unpublished M.S. thesis, 120 p.
Dashevsky, S.S., Schaefer, C.F., and Hunter, E.N., 2003, Bedrock geologic map of the Delta mineral belt, Tok mining district, Alaska: Alaska Division of Geological \& Geophysical Surveys Professional Report 122, 122 p., 2 sheets, scale 1:63,360. http://doi.org/10.14509/2923

Degenhart, C.E., 1978, Annual Progress Report, Paleozoic Schist Belt, Volume III: Unpublished report for Ahtna, Inc, WGM Inc., 83 p. (Held by Ahtna, Inc., Glennallen, Alaska)

Dusel-Bacon, Cynthia, Holm-Denoma, C.S., Jones, J.V. III, Aleinikoff, J.N., and Mortensen, J.K., 2017, Detrital zircon geochronology of quartzose metasedimentary rocks from parautochthonous North America, east-central Alaska: Lithosphere, v. 9, p. 927-952.

Dusel-Bacon, Cynthia, Hopkins, M.J., Mortensen, J.K., Dashevsky, S.S., Bressler, J.R. and Day, W.C., 2006, Paleozoic tectonic and metallogenic evolution of the pericratonic rocks of east-central Alaska and adjacent Yukon, in Colpron, Maurice and Nelson, J.L., eds., Paleozoic Evolution and Metallogeny of Pericratonic Terranes at the Ancient Pacific Margin of North America, Canadian and Alaskan Cordillera: Geological Association of Canada, Special Paper 45, p. 25-74.

Emond, A.M., CGG, Burns, L.E., Graham, G.R.C., and CGG Land (US) Inc., 2015, Tok electromagnetic and magnetic airborne geophysical survey data compilation: Alaska Division of Geological \& Geophysical Surveys Geophysical Report 2015-2. http://doi.org/10.14509/29347

Foley, J.Y., 1984, Petrology, geochemistry, and geochronology of alkaline dikes and associated plutons in the eastern Mount Hayes and western Tanacross quadrangles, Alaska: Fairbanks, Alaska, University of Alaska Fairbanks, M.S. thesis, 95 p. Franklin, J.M., Gibson, H.L., Jonasson, I.R., Galley, A.G., 2005, Volcanogenic massive sulfide deposits, in Hedenquist, J.W., Thompson, J.F.H., Goldfarb, R.J., and Richards, J.P., eds., Economic Geology 100th Anniversary Volume: Society of Economic Geologists, p. 523-560. 
Gaccetta, J.D. and Church, S.E., 1989, Lead isotope data base for sulfide occurrences from Alaska: U.S. Geological Survey, Open-File Report, 89688, $63 \mathrm{p}$.

Godwin, C.I., Gabites, J.E., and Andrew, Anne, 1988, Leadtable: A galena lead isotope data base for the Canadian Cordillera: British Columbia Geological Survey, Paper 1988-4, 188 p.

Goldfarb, R.J., Baker, Timothy, Dubé, Benoít, Groves, D.I., Hart, C.R.J., Gosselin, Patrice, 2005, Distribution, character, and genesis of gold deposits in metamorphic terranes, in Hedenquist, J.W., Thompson, J.F.H., Goldfarb, R.J., and Richards, J.P., eds., Economic Geology 100th Anniversary Volume: Society of Economic Geologists, p. 407-450.

Halley, Scott, Dilles, J.H., and Tosdal, R.M., 2015, Footprints-Hydrothermal alteration and geochemical dispersion around porphyry copper deposits: Society of Economic Geologists (SEG) Newsletter, v. 100, p. 1-17.

Holm-Denoma, C.S., Sicard, K.R., Twelker, Evan, 2020, U-Pb Geochronology of igneous and detrital zircon samples from the Tok River area, eastern Alaska Range, and Talkeetna Mountains, Alaska: Alaska Division of Geological \& Geophysical Surveys Raw Data File 2020-3, 19 p. http://doi.org/10.14509/30439

Illig, P.E., 2015, Geology and origins of the Peak gold-copper-silver skarn deposit, Tok, Alaska: University of Alaska Fairbanks, M.S. thesis, 153 p. Ishihara, Shunso, Hashimoto, Morio, and Machida, Minoru, 2000, Magnetite/Ilmenite-series Classification and Magnetic Susceptibility of the Mesozoic-Cenozoic Batholiths in Peru: Resource Geology, v. 50, p. 123-120.

Klein, C., 1983, Diagenesis and metamorphism of Precambrian banded iron-formations, in Trendall A. F. and Morris R. C., eds, Iron-formations: Facts and Problems, Elsevier, Amsterdam, p. 417-469. Lange, I.M., Nokleberg, W.J., Newkirk, S.R., Aleinikoff, J.N., Church, S.E., and Krouse, H.R., 1993, Devonian volcanogenic massive sulfide deposits and occurrences, southern Yukon-
Tanana Terrane, eastern Alaska Range, Alaska: Economic Geology, v. 88, p. 344-376.

Leach, D.L., Sangster, D.F., Kelly, K.D., Large, R.R., Garven, Grant, Allen, C.R., Gutzmer, Jens, and Walters, Steve, 2005, Sediment-hosted lead-zinc deposits: a global perspective, in Hedenquist, J.W., Thompson, J.F.H., Goldfarb, R.J., and Richards, J.P., eds., Economic Geology 100th Anniversary Volume: Society of Economic Geologists, p. 561-607.

McCoy, D.T., Newberry, R.J., Layer, P.W., DiMarchi, J.J., Bakke, Arne, Masterman, J.S., and Minehane, D.L., 1997, Plutonic-related gold deposits of Interior Alaska: Economic Geology, Monograph 9, p. 191-241.

Meinert, L.D., Dipple, G.M., and Nicolescu, Stefan, 2005, World Skarn Deposits, in Hedenquist, J.W., Thompson, J.F.H., Goldfarb, R.J., and Richards, J.P., eds., Economic Geology 100th Anniversary Volume: Society of Economic Geologists, p. 299-336.

Middlemost, E.A.K., 1994, Naming materials in magma/igneous rock system: Earth Science Reviews, v. 37, p. 215-224.

Mortensen, J.K., Nesbitt, B.E., and Rushton, R.W., 1992, Preliminary observations on the geology and geochemistry of quartz veins in the Klondike district, west-central Yukon: Yukon Geology, v. 3, p. 260-270.

Naibert, T.J., Werdon, M.B., Lande, Lauren, and Wypych, Alicja, 2016, Trace-element geochemical data from stream sediments collected in the Tok River area, Tanacross A-5 and A-6 quadrangles, Alaska in 2016: Alaska Division of Geological \& Geophysical Surveys Raw Data File 2016-10, 3 p. http://doi.org/10.14509/29688

Newberry, R.J., 2000, Mineral deposits and associated mesozoic and tertiary igneous rocks within the interior Alaska and adjacent Yukon portions of the 'Tintina Gold Belt': a progress report, in Tucker, T.L., and Smith, M.T., session chairs, The Tintina Gold Belt: Concepts, Exploration, and Discoveries: Vancouver, British Columbia, British Columbia and Yukon Chamber of Mines Special Volume 2, p. 59-88. 
Newberry, R.J., Burns, L.E., Solie, D.N., and Clautice, K.H., 1988, A revised geologic model for the North Star Gold Belt, interior Alaska: progress report: Alaska Division of Geological \& Geophysical Surveys Public Data File 88-23, 21 p. http://doi.org/10.14509/1372

Nichols, O.G., 2013, Mineralization related to the biotite syenite at the Money Knob intrusionrelated gold deposit, Livengood, Alaska: Golden, Colorado School of Mines, unpublished M.S. thesis, $116 \mathrm{p}$.

Nitsch, K.H., 1971, Stability relations of paragenesis containing prehnite and pumpellyite: Contributions to Mineralogy and Petrology, v. 30, p. 240-260.

Nokleberg, W.J., Aleinikoff, J.N., Bond, G.C., Ferrians, O.J., Jr., Herzon, P.L., Lange, I.M., Miyaoka, R.T., Richter, D.H., Schwab, C.E., Silva, S.R., Smith, T.E., and Zehner, R.E., 2015, Geologic maps of the eastern Alaska Range, Alaska (44 quadrangles, 1:63,360 scale), with descriptions and interpretations of map units: Alaska Division of Geological \& Geophysical Surveys Report of Investigation 2015-6, 64 p., 45 sheets, scale 1:63,360. http://doi.org/10.14509/29444

Powell, Roger, Condliffe, D.M., and Condliffe, Eric, 1984, Calcite-dolomite geothermometry in the system $\mathrm{CaCO}_{3}-\mathrm{MgCO}_{3}-\mathrm{FeCO}_{3}$ : an experimental study: Journal of Metamorphic Geology, v. 2, p. 33-41.

Rao, P.D., ed., 1988, Hydrometallurgy of complex sulfide ores, process development: University of Alaska Mineral Industry Research Laboratory Report No. 81, 166 p.

Raymond, L.M., 2018, Gold and base metal mineralization of the Dolphin intrusion-related gold deposit, Fairbanks Mining District, Alaska: Fairbanks, University of Alaska Fairbanks, unpublished M.S. thesis, 83 p.

Rhyolite Resources Ltd., 2019, Projects Overview: http://www.rhyoliteresources.com/s/Projects.asp (last accessed January 17, 2019)

Seedorff, Eric, Dilles, J.H., Proffett, J.M. Jr., Einaudi, M.T., Zurcher, Lukas, Stavast, W.J.A., Johnson,
D.A., and Barton, M.D., 2005, Porphyry deposits: Characteristics and origin of hypogene features, in Hedenquist, J.W., Thompson, J.F.H., Goldfarb, R.J., and Richards, J.P., eds., Economic Geology 100th Anniversary Volume: Society of Economic Geologists, p. 251-298.

Sharp, Z.D., Essene, E.J., and Kelly, W.C., 1985, A re-examination of the arsenopyrite geothermometer: pressure considerations and applications to natural assemblages: The Canadian Mineralogist, v. 23, p. 517-534.

Shoji, Tetsuya, 1978, Phase relations in the system $\mathrm{CaO}-$ $\mathrm{FeO}_{\mathrm{x}}-\mathrm{SiO}_{2}$ in $\mathrm{H}_{2} \mathrm{O}-\mathrm{CO}_{2}$ mixtures: Journal of the Japanese Association of Mineralogists, Petrologists and Economic Geologists, v. 73, p. 231-240.

Sicard, K.R., Naibert, T.J., Hubbard, T.D., Twelker, Evan, Wypych, Alicja, Werdon, M.B., Willingham, A.L., Gillis, R.J., Lande, L.L., and Newberry, R.J., 2017, Geologic map of the Tok River area, Tanacross A-5 and A-6 quadrangles, eastern Alaska Range, Alaska: Alaska Division of Geological \& Geophysical Surveys Preliminary Interpretive Report 2017-3, 15 p., 1 sheet, scale 1:63,360. http://doi.org/10.14509/29722

Singer, D.A., Curtin, G.C., and Foster, H.L., 1976, Mineral resources map of the Tanacross Quadrangle, Alaska: U.S. Geological Survey Miscellaneous Field Studies Map 767-E, 1 sheet, scale 1:250,000.

Symmes, G.H. and Ferry, J.M., 1992, The effect of whole-rock $\mathrm{MnO}$ on the stability of garnet during metamorphism, J. Metamorphic Geol., v. 10, p. 221-237.

Toulmin, Preistley III., Barton, P.B., and Wiggins, L.B., 1991, Commentary on the sphalerite geobarometer: American Mineralogist, v. 76, p. 1,038-1,051.

U.S. Geological Survey, 2018, Alaska Resource Data File (ARDF). Online link (https://ardf.wr.usgs. gov; updated March 2018).

Wen, Hanjie; Zhu, Chuanwei; Zhang, Yuxu; Cloquet, Christophe; Fan, Haifeng; and Fu, Shaohong, 2016, $\mathrm{Zn} / \mathrm{Cd}$ ratios and cadmium isotope evidence for the classification of lead-zinc deposits: Scientific Reports, v. 6, 8 p. 
Wilson, F.H., Hults, C.P., Mull, C.G., and Karl, S.M., 2015, Geologic map of Alaska: U.S. Geological Survey Scientific Investigations Map 3340, 197 p., 2 sheets, scale 1:1,584,000.

Winchester, J.A., and Floyd, P.A., 1976, Geochemical magma type discrimination: application to altered and metamorphosed basic igneous rocks: Earth and Planetary Science Letters, v. 28, p. 459-469. Wypych, Alicja, Sicard, K.R., Twelker, Evan, Freeman, L.K., Lande, Lauren, and Reioux, D.A., 2015, Major-oxide and trace-element geochemical data from rocks collected in 2015 in the Tok area, Tanacross A-5, A-6, and parts of adjacent quadrangles, Alaska: Alaska Division of Geological \& Geophysical Surveys Raw Data File 2015-15 v. 1.1, 3 p. http://doi.org/10.14509/29517

Wypych, Alicja, Sicard, K.R., Gillis, R.J., Lande,
L.L., Naibert, T.J., Newberry, R.J., Twelker, Evan, Werdon, M.B., and Willingham, A.L., 2016, Major-oxide and trace-element geochemical data from rocks collected in the Tok River area, Tanacross A-5 and A-6 quadrangles, Alaska in 2016: Alaska Division of Geological \& Geophysical Surveys Raw Data File 2016-9, 3 p. http://doi.org/10.14509/29685

Wypych, Alicja, Naibert, T.J., Athey, J.E., Newberry, R.J., Sicard, K.R., Twelker, Evan, Werdon, M.B., Willingham, A.L., and Wyatt, W.C., 2018, Major-oxide and trace-element geochemical data from rocks collected in 2018 for the Northeast Tanacross project, Tanacross C-1, C-2, D-1, and D-2 quadrangles, Alaska: Alaska Division of Geological \& Geophysical Surveys Raw Data File 2018-4, 4 p. http://doi.org/10.14509/30113 